\title{
Skill-based Mathematics Questions: What Do Middle School Mathematics Teachers Think about and How Do They Implement Them?
}

\author{
Mahmut Kertil $^{a}$, Hande Gülbağcı Dede ${ }^{b}$ and Emine Gülen Ulusoy \\ ${ }^{a}$ Marmara University, Ataturk Faculty of Education, İstanbul/Turkey (ORCID: 0000-0002-0633-7144) \\ ${ }^{\mathbf{b}}$ Marmara University, Ataturk Faculty of Education, İstanbul/Turkey (ORCID: 0000-0002-5427-5400) \\ ${ }^{\mathbf{c}}$ Marmara University, Ataturk Faculty of Education, İstanbul/Turkey (ORCID: 0000-0003-2854-7617)
}

Article History: Received: 27 July 2020; Accepted: 26 December 2020; Published online: 3 February 2021

\begin{abstract}
This study aims to investigate middle school mathematics teachers' opinions about PISA-like skill-based mathematics questions, ways of implementing these questions during their in-class practices, and needs for a professional support. Adopting a mixed-method approach, at first, we collected the qualitative data through semi-structured interviews with 10 middle school mathematics teachers. Later, a questionnaire was developed depending on the qualitative data, and by using a survey method we collected the quantitative data from 217 middle school mathematics teachers working in Istanbul. The qualitative and quantitative data show that teachers have positive ideas about the nature of the skill-based mathematics questions. The frequency of using these questions in mathematics classes increases by the eighth grade and teachers generally use these questions once a week. Teachers' ways of implementing these questions in mathematics classes appears generally as giving homework and checking, classroom discussion, and privately solving the questions coming from students. Although teachers' ways of implementing these questions have some differentiations according to school types, but this differentiation is not statistically significant. Most of the teachers use the questions released by Ministry of National Education (MoNE) monthly and they evaluate the quality of these questions as suitable. Teachers evaluate the mathematics textbooks served out by MoNE as insufficient in terms of the quantity of involving these questions. In addition, some criticism appeared about the quality of the questions involved in the supplementary resources released by private publishers. The study also revealed that most of the teachers need a professional development course about the skill-based questions such as writing quality questions and developing their problem solving skills. The usage of PISA-like, skill-based questions in high-stakes testing (e.g., high school entrance examination) have been affecting teachers' in-class practices, yet it is difficult to say that this effect is on the true way.
\end{abstract}

Keywords: Skill-based questions, high school entrance examination (LGS), high-stakes testing, mathematics teachers, PISA, PISA-like questions

DOI:10.16949/turkbilmat.774651

Öz: Bu çalışmanın amacı ortaokul matematik öğretmenlerinin "yeni nesil" diye bilinen, PISA tarzı beceri temelli sorulara ilişkin düşüncelerini, sınıf içerisinde nasıl uyguladıklarını ve mesleki gelişim ihtiyaçlarını ortaya koymaktır. Karma yöntem metodunun kullanıldığı araştırmada ilk olarak 10 ortaokul matematik öğretmeni ile yarı-yapılandırılmış görüşmeler yoluyla nitel veriler elde edilmiştir. Daha sonra, nitel bulgular temel alınarak oluşturulan anket, tarama yöntemiyle İstanbul genelinde 217 ortaokul matematik öğretmenine uygulanarak nicel veriler elde edilmiştir. Nitel ve nicel bulgularda öğretmenlerin beceri temelli soruların doğasına ilişkin olumlu görüşler belirttikleri görülmüştür. Öğretmenlerin sınıf içi uygulamalarında bu sorulara yer verme oranı 8 . sınıf düzeyinde artmakta ve genellikle haftada bir uygulandığı görülmektedir. Bu soruların sınıflarda uygulama şekli genellikle ödev verip kontrol etme, sınıf tartışması yaptırma ve öğrencilerden gelen soruları bireysel çözme şeklinde olup çalışılan okul türüne göre farklılıklar gösterse de, bu farklılık istatistiksel olarak manidar değildir. Öğretmenlerin büyük çoğunluğunun kaynak olarak Milli Eğitim Bakanlığı tarafından yayınlanan beceri temelli soruları kullandıkları ve bu soruları nitelik olarak olumlu buldukları görülmektedir. Milli Eğitim Bakanlığı ders kitaplarında bu tür soruların nicelik olarak yetersizliğine ve özel yayınevleri tarafından yayımlanan kitaplardaki soruların ise niteliğine yönelik bazı eleştiriler ortaya çıkmaktadır. Öğretmenlerin çoğunluğunun beceri temelli sorulara ilişkin soru yazımı, problem çözme becerisini geliştirme gibi çeşitli konularda hizmet içi eğitim faaliyetine ihtiyaç duyduğu görülmektedir. Beceri temelli soruların LGS gibi merkezi sınavlarda kullanılıyor olması, öğretmenlerin sınıf içi uygulamalarını etkilemekte fakat bu etkinin olumlu yönde olduğunu söylemek henüz mümkün görünmemektedir.

Anahtar Kelimeler: Beceri temelli sorular, Liselere Giriş Sınavı (LGS), matematik öğretmenleri, merkezi sınavlar, PISA, PISA tipi sorular

Türkçe sürüm için tıklayınız

\section{Introduction}

Large-scale, high-stakes tests have important functions in terms of evaluating the education system, obtaining feedback, providing accountability, and deciding on reforms to be made (Diamond, 2007; Resnick \& Resnick, 1992). On the other hand, these exams have serious positive or negative effects on the education system, including teachers' in-class practices as they allow students to be selected, placed and ranked (Diamond, 2007;

Citation Information: Kertil, M., Gülbağcı-Dede, H., \& Ulusoy, E. G. (2021). Skill-based mathematics questions: What do middle school mathematics teachers think about and how do they implement them? . Turkish Journal of Computer and Mathematics Education, 12(1), 151186. http://doi.org/10.16949/turkbilmat.774651 
Özer-Özkan \& Acar-Güvendir, 2018; Smith \& Rottenberg, 1991; Stecher, 2002). Large-scale, high-stakes tests can distort education system by producing results such as emergence of exam-oriented teaching practices (test technique, etc.) or elimination of the important subjects and learning outcomes that are not emphasized in the exams (Baştürk, 2011; Çepni \& Kaya, 2002; Koretz, 2005; Miller, Linn, \& Gronlund, 2009; Smith \& Rottenberg, 1991; Stecher, 2002).

One of the centralized, high-stakes tests held in Turkey plays a role in the placement of $8^{\text {th }}$ grade students to high schools. This exam has been subject to frequent changes with the effects of the results obtained from international exams such as PISA and TIMSS along with the changes in the curriculum (Ormanc1, 2019). Secondary School Selection and Placement Examination (OKS), Level Determination Examination (SBS) and Transition to Secondary Education from Basic Education (TEOG) exams were held in the previous years for placement to high school institutions and as of 2018 the High School Entrance System (LGS) has been implemented. PISA type (so-called skill-based) questions which are also called "new generation" questions have taken their place in our education system with the transition to LGS. These skill-based questions which started to be used with the effect of the Programme for International Student Assessment (PISA) exams are new to students and teachers that they have not encountered before and are not accustomed to. Students and teachers undergo an adaptation and learning process for these skill-based questions (Erden, 2020; Güler, Arslan, \& Çelik, 2019). The fact that the LGS examination, which is vitally important for students, consists of skill-based questions requires that such practices should be included more frequently in course contents and in the curricular materials. Eventually, the assessment of students with knowledge and skills that they have not learned and experienced throughout their education life, will pose an important problem in terms of the alignment between the content of high-stakes tests and the curriculum objectives and so the validity of the test (Diamond, 2007; Erden, 2020; Koretz, 2005).

The skill-based questions have been on our agenda since 2018 with transition to LGS and their direct and indirect effects on mathematics education is an issue that needs to be researched. From the perspective of teachers, it is likely that they have developed positive or negative opinions towards skill-based questions. More importantly, whether teachers employ this skill-based assessment and evaluation approach in their classroom practices, how often and how they implement it, and whether their current pedagogical content knowledge is sufficient are the main issues to be examined. Determining the professional knowledge and skills that teachers might need regarding the skill-based questions will also provide guidance in designing more efficient teacher education programs and in-service professional development activities. Accordingly, the purpose of this study is to reveal the opinions of middle school mathematics teachers regarding the skill-based questions, namely "new generation" questions and to reveal how these questions appear in their in-class practices. The research questions and sub-questions guiding the study are as follows:

What are middle school mathematics teachers' thoughts on the nature of skill-based questions and their use in mathematics learning and teaching process?

a) What are teachers' opinions on the nature of skill-based questions?

b) How often and how do teachers implement skill-based questions in their lessons?

c) What are teachers' opinions about the curricular resources containing skill-based questions?

d) What are teachers' opinions on professional development activities for in-service teachers regarding the skill-based questions?

\section{1. How Do Large-Scale, High-Stakes Tests Affect Education System?}

As stated previously, high-stakes tests involving centralized examinations are of significance in terms of determining the general state of the education system, increasing the quality of the system by supplying feedback, and providing accountability (Blazar \& Pollard, 2017; Diamond, 2007; Resnick \& Resnick, 1992). Although high-stakes tests serve an important function regarding the accountability of teachers, school administrators and politicians, it is also stated that an accountability mechanism solely based on high-stakes tests cannot be acceptable for the integrity of education system (Koretz, 2005; Linn, 2000; Nichols, 2007).

High-stakes tests have psychological and social effects on both students and teachers. In the literature, it is pointed out that just as high-stakes tests do not increase learning outcomes, they also have negative effects on students such as loss of interest in school subjects, exam anxiety, spending less time with friends, feeling responsible to the family and feeling of failure (Kumandaş \& Kutlu, 2014; Nichols, 2007). Smith and Rottenberg (1991) reported the negative effects of high-stakes tests under four themes in a study they conducted with a group of teachers using clinical interviews and classroom observations during an academic year. These are (i) determining what teachers will teach according to the exam, neglecting or omitting the subjects and concepts from the course content that are excluded in the external tests; (ii) undesirable pedagogy, shaping the instructional methods of teachers (e.g., teaching of test techniques); (iii) disrupting the school environment by 
making students to focus only on selection and placement; (iv) the anxiety of getting a low-score negatively affect teachers and students.

It is known that high-stakes tests are among one of the important facts that shape teachers' in-class practices (Çetin \& Ünsal, 2019; Çepni \& Kaya, 2002; Smith \& Rottenberg, 1991; Stecher, 2002). They might have some positive aspects such as motivating teachers, encouraging them to be ambitious and to employ innovative teaching practices (Stecher, 2002). On the other hand, some results that do not align with the goals of the education system might arise out of high-stakes testing-oriented teaching and concentrating on the exam topics rather than the subjects and learning outcomes of the curriculum exemplifies these results (Çetin \& Ünsal, 2019; Çepni \& Kaya, 2002; Diamond, 2007; Smith \& Rottenberg, 1991; Stecher, 2002). The alignment between the scope and content of the high-stakes test questions and curriculum is important for the test validity as well as for guiding teachers' in-class practices properly (Koretz, 2005). Blazar and Pollard (2017) and Koretz (2005) demonstrated that test-oriented mathematics teaching adversely affected teachers' inquiry-based and ambitious teaching practices. Students' anxiety level, their eagerness to do well in the exams, and high expectations of families and school administrations cause teachers not to act freely while creating course content and choosing teaching methods or techniques (Smith \& Rottenberg, 1991). Furthermore, the high expectations of students, teachers and administrators about the results of high-stakes tests affect teachers both socially and psychologically (Çetin \& Ünsal, 2019; Özer-Özkan \& Acar-Güvendir, 2018).

\subsection{Effects of International Exams on the Education System}

International assessment exams such as PISA and TIMSS behave as a significant political element that force countries to introduce educational reforms by determining their shortcomings and revealing the positions of nations compared to others (Cantley, 2019; Gürlen, Demirkaya \& Doğan, 2019; TEDMEM, 2017). Hence, PISA results deeply affect the education system and education policies of many countries (Breakspear, 2012, 2014; Cantley, 2019; Grek, 2009). However, according to Cantley (2019), it should be known that PISA results might lead to wrong political decisions in mathematics education, since there has been a debate whether the items used can measure various abilities. PISA demonstrates the quality of education system by comparing OECD countries in areas such as science and mathematics literacy and reading skills. Turkey performs poorly in the core areas of reading, mathematics, and science literacy among OECD countries (Kabael, 2019; Taş, Arıcı, Ozarkan, \& Özgürlük, 2016). According to PISA 2018 results, although the average score of Turkey has increased compared to previous years, it is still below the OECD average in all three areas (Karip, 2020).

Several reforms are also carried out in Turkish education system as a result of the outcomes obtained from international assessment exams such as PISA and TIMSS and nationally held high-stakes tests (Aksit, 2007). Within the scope of these reform activities, as of 2004, the teacher-centered didactic approach in curriculum has been abandoned at all levels and a student-centered, skill-oriented and formative approach which places emphasis on alternative assessment tools have been adopted instead (Aksit, 2007; Özer-Özkan \& Acar Güvendir, 2018). Subsequently, in 2013 and 2018, primary, secondary, and high school curricula were revised. Nevertheless, since old habits and beliefs are resistant to change, it has not been easy for teachers to understand and apply the renewed curriculum properly to its purpose (Duru \& Korkmaz, 2010; Zembat, 2010). Evidently, teaching methods and strategies of teachers cannot be changed much by reforms alone (Diamond, 2007). In conclusion, despite the reforms in the curriculum carried out in our country, the majority of mathematics teachers still prefer to employ direct instruction method intensively, in preference to student-centered teaching methods (Aktepe, Tahiroğlu, \& Acer, 2015; Temizöz \& Özgün-Koca, 2008).

Educational reforms include changing not only the curriculum but also the high-stakes tests involving central exams for transition to high school and university. For the placement of $8^{\text {th }}$ grade students to more qualified schools such as Anatolian and science high schools OKS, SBS and TEOG tests were applied in the last fifteen years respectively, and in 2017-2018 academic year the name has been changed to LGS ultimately. As a matter of fact, it can be claimed that the most significant effect of PISA exams on Turkish education system has been the increase in the number of contextual and skill-based questions in LGS, which was implemented in 2018, and in other central exams as well, compared to previous years (Erden, 2020; Güler \& Ülger, 2019; Gürbüz, 2019). In the high-stakes tests held in Turkey, especially in mathematics, the use of PISA-like, skill-based questions is remarkably increased

\subsection{Skill-Based Questions}

The questions created with a set of objective and open-ended test items, which presents a context supported by elements such as written material, graphics, tables, charts, pictures and diagrams and requires the use of highlevel metal processes such as interpretation, analysis, problem solving and mathematical reasoning within this context is known as interpretive exercises (Miller et al., 2009). In Turkish education system, it is called as skillbased questions. Skill-based questions (so called interpretive exercises) allow educators to measure higher-order thinking skills that are unlikely to be measured by simple objective test items. However, these questions have also several shortcomings that because they require a high level of reading skill, it is difficult to generate 
qualified items, and they do not measure skills such as social communication and self-expression (Miller et al., 2009).

The items of PISA can be accepted as a good example of skill-based questions. In PISA mathematical literacy, mathematical processes include (i) formulating situations mathematically, (ii) employing mathematical concepts, facts, procedures and reasoning, (iii) interpreting and evaluating mathematical outcomes. Under each process, it focuses on the competencies of communication, mathematising, representation, reasoning and argument, devising strategies, and using formal mathematical language and operations (Kabael, 2019; OECD, 2018). The reality and diversity of the contexts are also important in PISA questions and in skill-based questions in general (Güler \& Ülger, 2019; Kabael, 2019). As stated by Çepni (2019), in order for Turkey to succeed in PISA exams, first, the skills in the curricula should be treated as context-based rather than theoretical oriented; and second, high-stakes tests should consist of context and skill-based questions as in PISA. In fact, the entire LGS mathematics section has been composed of skill-based questions since 2018. According to Güler and Ülger (2019), although it is unlikely to claim that the real-life contexts are as realistic as in PISA questions, evidently LGS skill-based questions require more higher-order thinking skills compared to the questions of previous years.

There are numerous studies examining the opinions, thoughts and performances of teachers, pre-service teachers or students regarding PISA questions (Aydın \& Özgeldi, 2019; Kabael \& Barak, 2016; İpek, Turgut, \& Tunga, 2016; Radišić \& Baucal, 2018). In a study conducted by Kabael and Barak (2016) by using several PISA questions, pre-service mathematics teachers scored below the expected level in terms of mathematising and accordingly mathematical literacy. Aydın and Özgeldi (2019), on the other hand, demonstrated that while solving the PISA questions, pre-service mathematics teachers had the most difficulty when contextual knowledge was required and when they generated mathematical arguments specific to the context which appeared in the stem of the question. In a study carried by Radišić and Baucal (2018), mathematics teachers indicated that students had difficulties with PISA questions since they were not familiar with them and such questions were not introduced in the classrooms. These studies that focus exclusively on PISA questions, commonly pointed out that teachers, pre-service teachers, and students are not accustomed to the skill-based questions and have difficulties while solving them.

As the skill-based questions in high-stakes tests are a fairly new construct in Turkey, there are considerably few studies regarding them, and these studies solely focus on teachers' views (Erden, 2020; Güler et al., 2019). In the study conducted by Güler et al. (2019), mathematics teachers stated positive opinions on the quality of the skill-based questions in LGS, however they also pointed out that the questions were rather difficult for both students and teachers and the curricular materials including these questions were insufficient. Still in a study in which teachers' opinions were analyzed by Erden (2020), Turkish mathematics and science teachers stated that the curriculum did not provide adequate guidance and the curricular materials were insufficient. The teachers also indicated the need for professional development support for teachers concerning the skill-based questions. Teachers' thoughts on skill-based questions, the difficulties they face, their need for curricular materials and professional support seem worthy of further investigation (Erden, 2020; Güler et al., 2019). The aim of this study is to reveal the opinions of middle school mathematics teachers concerning skill-based questions, how they apply them in their classroom practices, their opinions regarding the curricular materials which includes such questions and their needs for professional development.

\section{Method}

The mixed method that combines qualitative and quantitative research methods was used in the study. The design of mixed method researches appear under different names in the literature. The design which employed in this study is referred to exploratory sequential design (Creswell \& Plano-Clark, 2011) and sequential mixed design in the literature (Teddlie \& Tashakkori, 2009). In the studies using this design (QUALITATIVE $\rightarrow$ QUANTITATIVE), initially qualitative data are collected to examine a case, subsequently quantitative data are collected to explain the relationship between qualitative data (Creswell \& Plano-Clark, 2011). The research design and flowchart of the study is outlined in Figure 1.



Figure 1. Flowchart of the study 
As seen in Figure 1, in accordance with the purpose of the study, first the qualitative stage was finalized by semi-structured interviews with middle school mathematics teachers. Subsequently, a questionnaire to be utilized in quantitative stage was developed by using the findings obtained from the analysis of the qualitative data. The questionnaire was applied to middle school mathematics teachers working in Istanbul; thus, the quantitative phase of the study was finalized with survey method. Greene, Caracelli and Graham (1989) state that mixed method could be employed for various reasons in research. In this study, the mixed method is utilized for complementarity and development purposes. Based on the findings obtained through interviews, a questionnaire was developed as a quantitative data collection tool. Therefore, it can be claimed that the mixed method is used for development purposes. Owing to the use of the mixed method for complementarity, the findings obtained by using qualitative and quantitative methods were interpreted with a holistic approach.

\subsection{Participants}

In the qualitative phase of the study, middle school mathematics teachers were selected with the convenient sampling method which is one of the purposive sampling methods (Yıldırım \& Şimşek, 2018). To ensure the diversity of teachers participating in the interview, the school category and experience level were taken into account. Moreover, attention was paid that the teachers to be selected had at least five years of teaching experience and that they taught $8^{\text {th }}$ graders for the last two years. The reason why the teachers are required to have at least five years of experience is because they know the question types from previous exams such as TEOG and they teach students who will take LGS. In the study, a total of 10 middle school mathematics teachers were interviewed. The demographics of the teachers are presented in Table 1.

Table 1. Demographics of the teachers interviewed

\begin{tabular}{cccc}
\hline Teacher & Gender & Years of experience & School type \\
\hline T1 & Female & 5 & Private \\
T2 & Female & 5 & Public \\
T3 & Female & 5 & Public \\
T4 & Male & 12 & Public \\
T5 & Male & 10 & Public \\
T6 & Male & 13 & Private \\
T7 & Female & 5 & Public \\
T8 & Male & 10 & Public \\
T9 & Female & 28 & Public \\
T10 & Male & 11 & Private \\
\hline
\end{tabular}

217 mathematics teachers, who work in middle schools affiliated with the Ministry of National Education in Istanbul province participated in the quantitative phase of the study and they are selected by the convenient sampling method. In convenient sampling, participants are expected to volunteer or participate in the study only because they are present there. Volunteer participants differ from those who are reluctant in that they might be motivated and more interested in the study (Gay, Mills, \& Airasian, 2006). The distribution of the teachers participating in the questionnaire is given in Table 2.

Table 2. Distribution of the demographics of the mathematics teachers participating in the questionnaire

\begin{tabular}{llcc}
\hline Variables & & $\mathbf{n}$ & $\mathbf{\%}$ \\
\hline Gender & Female & 136 & 62.7 \\
& Male & 81 & 37.3 \\
\hline Institution where he/she works & Public & 153 & 70.5 \\
& Private & 64 & 29.5 \\
\hline Years of experience & Novice teacher (less than 1 year) & 2 & 0.9 \\
& $1-5$ years & 43 & 19.9 \\
& $6-10$ years & 121 & 55.8 \\
& $11-15$ years & 29 & 13.4 \\
& $16-20$ years & 22 & 10.1 \\
\hline The grade he/she attends since $2018-2019$ & 21 and above & - & - \\
academic year & $5^{\text {th }}$ grade & 120 & 59.7 \\
& $6^{\text {th }}$ grade & 143 & 71.1 \\
& $7^{\text {th }}$ grade & 149 & 74.1 \\
\hline
\end{tabular}


In the quantitative phase, female teachers accounted for $62.7 \%$ and male teachers accounted for $37.3 \%$ of teachers that participated in the study. While $70.5 \%$ of the teachers work in public schools, $29.5 \%$ work in private schools affiliated with MoNE. This ratio reflects the rate in the number of teachers working at secondary school level in Istanbul in the 2018-2019 academic year report of the Ministry of National Education (2019). Of all the participants, $19.9 \%$ have $1-5$ years, $55.8 \%$ have $6-10$ years, $13.4 \%$ have $11-15$ years, and $10.1 \%$ have 16 20 years of experience. There are no teachers with 21 and more years of experience. It can be assumed that the reason for the low number of novice teachers $(0.9 \%)$ is that no appointment has been made in Istanbul with KPSS in recent years. Since the year that skill-based questions introduced, $59.7 \%$ of teachers has taught $5^{\text {th }}$ graders, $71.1 \%$ has taught $6^{\text {th }}$ graders, $74.1 \%$ has taught $7^{\text {th }}$ graders, and $83.1 \%$ has taught $8^{\text {th }}$ graders.

\subsection{Data Collection Tools}

In the study, the qualitative data is collected by semi-structured interviews and the quantitative data is collected by a questionnaire which was developed by the researchers. The semi-structured interview form has open-ended questions suitable to the purpose of the study. During the interviews, the teachers were asked about their views on skill-based questions and the position of such questions in mathematics education and teaching. In addition, it was tried to reveal how teachers employ skill-based questions in mathematics lessons. Furthermore, teachers were also asked about what they think of the curricular materials (mathematics textbook, skill-based questions samples, books published by private publishers that contain skill-based questions. In order to discover the need for in-service professional development activities, teachers were asked about whether they participated in any training activity previously, whether they needed it, and if needed, what the content of this training was. A pilot interview was conducted with two mathematics teachers after the interview form was created. Subsequently, the necessary changes were made, and the form was finalized. The data of the pilot interview has not been reported in the study.

Semi-structured interviews were conducted with 10 mathematics teachers in the qualitative phase of the study. The questionnaire to be used in the quantitative phase was developed with the findings obtained from the analysis of the interview data. In accordance with the findings of the qualitative data and the research questions, it was decided that the questionnaire would consist of four parts in total. These parts cover teachers' views on (i) the nature of skill-based questions, (ii) the use of skill-based questions in classes, (iii) the curricular resources involving skill-based questions, and (iv) in-service professional development needs for skill-based questions.

In the first part of the questionnaire, there are nine statements reflecting the possible teachers' views about the nature of the questions. These nine statements are derived from the qualitative findings. Teachers were asked to choose to what extent the statements reflect their views (three-point Likert scale). During the interviews, all the teachers stated that the students had difficulty with skill-based questions, and they associated this difficulty with different reasons. Upon this finding, it was decided to add an item in the first part of the questionnaire concerning reasons for the student difficulties while solving the skill-based questions. In this item, seven reasons were provided, and teachers were asked to list these seven reasons from the most challenging to the least challenging. Based on the categories that emerged out of the interviews, a total of seven items were written in the second part of the questionnaire to see the general trend of how teachers implemented the skill-based questions in their classes. During the interviews, it was determined that the teachers use various types of curricular resources that included skill-based questions. Therefore, in the third part of the questionnaire, first, the teachers were asked what resource they used and second, they are asked to evaluate those resources separately according to eight criteria (question diversity, comprehensibility of questions, etc.). The last part of the questionnaire is related to in-service professional development activities regarding the skill-based questions. In the interviews, it was revealed that the teachers needed in-service training activities. Accordingly, teachers were asked if they needed for in-service professional development activities and if so, on which subjects this activity would be. The types of in-service professional development activities were grouped under six headings in total. The teachers, who stated that they participated in an in-service training activity were asked to indicate the subject of that activity and whether they found that training adequate.

Following the questionnaire was created, it was examined by a language expert for the use of proper language and five mathematics education experts were consulted to determine the content validity. The experts assessed each item in the questionnaire according to ten specified criteria. These criteria concern the item's language, understandability, relevancy, comprehensiveness, and consistency. Additionally, the experts were asked whether they had any opinions they would like to express, and the questionnaire was finalized by considering these opinions. The Krippendorff's Alpha coefficient was used for inter-rater agreement and was calculated as 0.82 . After the changes were made in line with the recommendations based on the expert opinions, a pilot study was conducted with 18 middle school mathematics teachers working outside of Istanbul. The length of the questionnaire and problems that might occur during the online administration were tried to be determined with the pilot study. Necessary adjustments were made after the pilot study and the questionnaire was finalized for administration (Appendix 1 (The questionnaire is provided with its original language)). 


\subsection{Collecting and Analyzing Data}

Semi-structured interviews were conducted face to face or by using online platforms, depending on the teachers' preference. The interviews lasted 15 to 20 minutes and were recorded with the permission of the participant. Content analysis was performed on the deciphered interview records. By means of content analysis, teachers' views were categorized and interpreted within the framework of similar concepts and themes (Yildirım \& Şimşek, 2018). The analysis of the data obtained from the interviews, was carried out by considering four main themes: (i) the nature of the questions, (ii) in-class practices, (iii) curricular resources, and (iv) in-service professional development activities. Under the theme of the nature of the questions, three categories and their sub-codes were created which are (i) opinions on skill-based questions, (ii) reasons for student difficulties, (iii) and the consequences of student difficulties. Under the theme of in-class applications of skill-based questions, there are two categories as (i) the kind of the lesson and (ii) the way of implementing. For the third theme, namely the curricular resources, two categories emerged as (i) the kind of the resource and (ii) properties of the questions in the resource. Finally, under the in-service professional training activities theme, four categories and their sub-codes were defined as (i) participation to an in-service training, (ii) the kind of activity attended, (iii) the need for in-service professional development training, and (iv) the kind of the professional development activity needed. The categories and codes under each theme were defined by two researchers. Subsequently, the two researchers analyzed a randomly selected interview separately. In these two analyzes, agreement between researchers was calculated as $85 \%$ (Miles \& Huberman, 1994). The remaining nine interviews were analyzed by one researcher.

The questionnaire utilized in the quantitative phase of the study was delivered online to middle school teachers working in Istanbul. The administration of the questionnaire takes approximately 9 minutes. In an attempt to determine the distribution of teachers' views, the frequency and percentage were calculated, and in several questions the chi-square test was used additionally to determine whether there was a difference between the teachers according to the institutions they work in. Average and median values were used in the analysis of the items that teachers were asked to rank.

\section{Findings}

The findings on the views of mathematics teachers regarding skill-based questions are reported in three parts. First, the qualitative findings obtained from the interviews and second the quantitative findings obtained from the questionnaire were introduced. Finally, the comparative analysis of qualitative and the quantitative findings were reported.

\subsection{Teachers' Views on Skill-Based Questions: Qualitative Findings}

The qualitative findings gathered from the interviews are presented under four subheadings in accordance with the research questions, namely (i) teachers' views on the nature of skill-based questions, (ii) teachers' views on their use in mathematics classes, (iii) teachers' views on curricular resources, and (iv) teachers' views on the need for in-service professional training activities.

\subsubsection{Teachers' Views on the Nature of Skill-Based Questions}

During the interviews, teachers were asked about their opinions regarding skill-based questions and their views on the nature of those questions. The findings demonstrate that teachers mostly consider skill-based questions positively in terms of mathematics education and teaching. Teachers' views on the nature of skillbased questions are presented in Table 3.

Table 3. Teachers' views on the nature of skill-based questions.

\begin{tabular}{ll}
\hline Codes & Teachers \\
\hline It measures higher-order thinking skills. & T1, T3, T5, T6, T7, T8, T10 \\
It is associated with reading skill. & T3, T6, T7, T8, T9 \\
It requires using conceptual knowledge rather than memorization. & T2, T3, T5, T7 \\
It is associated with real-life situations. & T5, T7, T8 \\
It requires an understanding of mathematics and interdisciplinary relationship. & T3
\end{tabular}

As seen in Table 3, the teachers expressed different views about the nature of skill-based questions. In line with these views, it can be assumed that teachers qualify skill-based questions differently from the traditional (drill and practice type) questions which are common in mathematics education. With regards to the nature of skill-based questions, teachers stated that these questions (i) measure higher-order thinking skills, (ii) require reading skills, (iii) are related to real-life situations, and (iv) require the ability to apply knowledge.

In addition to expressing their views on the nature of the questions, teachers also mentioned about their reflections on mathematics education. The most important of these reflections is in the student dimension. All the teachers pointed out that the students had difficulty while solving skill-based questions. Moreover, several 
teachers (T1, T2, T3, T5, T6, T7) stated that they or their colleagues might have similar difficulties as well as their students. For instance, T3 said:

T3: Actually, we as teachers feel bad when we see [skill-based questions]. We cannot understand it at the first look. It takes 1-2 minutes to understand. The students ask, "Even you do not understand it, how are we supposed to solve it in two minutes?" We can have difficulty as well because we did not have that kind of education. My colleagues also agree that $8^{\text {th }}$ grade questions are very difficult. Of course, it can be solved, but even though we are mathematics teachers we approach the questions uneasily, we stay behind saying that it is long, but students experience this so much more.

As can be understood from the quotation, T3 indicated that teachers as well as students might have difficulties while solving skill-based questions. The teachers assume that the difficulties that the students experience while solving skill-based questions stem from various reasons. According to the teachers, the first reason is that students are not accustomed to the skill-based question style and the use of the higher-order thinking skills that is required in problem solving (T2, T3, T4, T5, T7, T10). One of these teachers, T5, explained his opinion on this issue with the following words:

T5: Our teachers and students have difficulties because they are not used to this way of thinking. How was it asked in TEOG, in the past? If $2 x=8$, what is $x$ ? But now, such a thing is not possible in the new question style. Now, as well as we need to know this information, we also need to think about where, when, and at what stage we are going to use it or whether we will use it or need different information. Because our students would not like to think, therefore they have difficulties. They have a hard time because they are not used to thinking. In fact, there is a subtle point here, students struggle not because they cannot do it, but because they are not used to it.

T5 indicated that the students had difficulties since they were not accustomed to the higher-order thinking skills required in solving skill-based questions. T5 emphasizes that students have the potential to solve these questions and this can be achieved through classroom practices. According to the teachers (T2, T3, T7, T8) a further reason for students to struggle is that the skill-based questions has long textual parts and students do not comprehend what they read. Unlike other teachers, T2 believes that the reason why students have difficulty is that they do not know where and how to implement the given information.

The fact that the students have difficulties while solving skill-based questions produce different outcomes according to teachers. The first outcome is that students develop a negative attitude towards mathematics and skill-based questions due to these difficulties (T1, T2, T3, T4, T7, T8, T9, T10). Regarding the issue, T4 stated the following:

T4: Students develop negative thoughts when they faced with these questions. They say things like,

"I cannot do math, if that is math, I am out of here..." There are also those who do, who try to do something, but they cannot do very well.

According to T4, students might develop negative attitudes and thoughts towards the skill-based questions and mathematics lessons due to the difficulty they have while solving those questions. Although T1 agrees with T4 on that students have difficulties and develops negative attitudes, she states that students with high mathematics success enjoy solving such questions after a while. None of the teachers but T1 indicated that the students demonstrated a positive attitude towards the skill-based questions.

Another outcome is that students who are assessed academically at low and medium success level by teachers, have more difficulty while solving skill-based questions. In the words of the teachers, assessment and evaluation that carried out with skill-based questions downgrades students with medium scores to low scores (T1, T7, T9, T10). For instance, T7 stated the following:

T7: My colleagues and I have some complaints in that sense. With the new-generation questions, we actually lost medium level students. Because the good kids [high level of academic success] have difficulties but they study and try to solve them. The failed [low level of academic success] could not do well in TEOG, and now they cannot do as well. It did not bother them though. The medium level student, that student who tried a little more, is no longer here. There are only successful and unsuccessful students. Medium level students are in the mood that they cannot succeed anyway.

This situation of being loss and the struggle that $\mathrm{T} 7$ mentioned about students with low and medium level of academic success has been associated with LGS by several teachers. T6 and T9 believe that LGS addresses only a certain group of students. T6 expressed this view with the following words: 
T6: MoNE apply this exam for the 10\%, not for all Turkey. When I choose $20 \%$ of the students and apply the test, net average is around 16-17. When I apply it to whole school, net average is 6-7. There is a serious difference. This exam is not for the common.

T6 not only mentioned the difference in students' test scores but also stated that the exam appeals specifically to successful students. T1 and T10 suggested that to prevent students with medium and low academic success levels from losing interest in mathematics, conventional and traditional questions should also be included in LGS as well as skill-based questions.

\subsubsection{Views on the In-Class Use of Skill-Based Questions}

During the interviews, teachers were asked how they implemented skill-based questions in their mathematics lessons. One of the striking findings is that most teachers (T1, T2, T3, T4, T5, T8, T10) used skill-based questions in their lessons after finishing their lectures and after solving practice questions. In other words, it is understood that teachers do not consider skill-based questions as activities that can be applied in various ways, instead they employ them as traditional problem-solving activities. T2, who apply traditional problem-solving, claims that the application is not very efficient in the following words:

T2: There are problems in how to teach this. What should a teacher do to make students understand those questions easily? You are explaining one [solution], they understand and solve it, very well. But when it is a little bit different, you go back to square one again...There is no improvement.

T2 stated that it is not possible to increase the performance of students by merely solving problems, however she does not know exactly what to do to this end. Only two teachers (T5, T6) mentioned practices such as projects, mathematical modeling that require group or teamwork, or STEM activities to develop the skills required by skill-based questions. For instance, T5 said, "I think that if a modeling activity is implemented in the class, it will be much more beneficial for students' thinking skills. I, myself at least use it”. This finding suggests that most teachers believe that solving numerous skill-based questions will lead to improvement in students' performance. A similar thought was expressed by T10 as follows:

T10: [LGS] is a test that measures high-level skills, but the problem here is that we are trying to increase these high-level skills by solving problems. While there is unfortunately no move to provide students learn those skills, expecting it from children... I mean, we are trying to achieve it by solving problems... To prepare students for an exam should be a result, but it is a goal for us.

T10 expresses that solving numerous skill-based questions to provide students acquire skills that we try to assess with skill-based questions is wrong. According to T10, the main goal here is not to teach students higherorder thinking skills, but to prepare them for LGS. This outcome is one of the most prominent indicators of the adverse effects of LGS on teachers' practices.

The teachers (T1, T3, T4, T7, T9) pointed out that they employ such questions especially in elective mathematics classes and in mathematic courses optionally organized by the school. The first reason of this situation is that teachers usually cover the subjects and solve practice-style questions in the compulsory lessons to complete the mathematics curriculum. For instance, T7 stated that at the beginning of the semester she spared time for the solution of skill-based questions in compulsory classes, but later gave up this practice because she lagged far behind the curriculum.

Another significant finding that emerged from the interviews is that the physical adequacy of classes and access to the teaching materials (resources) seriously affect teachers' use of skill-based question in their lessons. For instance, it becomes very difficult for teachers to employ skill-based questions when there is no smart board in the classroom. All but T7 have smart boards in their classrooms. T2 who has access to a smart board, explains how she solves the skill-based questions as follows:

T2: We project the question on the board, then the students read it. I wait for a while. "What do you get here?" I sometimes ask. If nobody has any idea, I ask questions like "What are we asked here? What has been given to us?" in the form of a small class discussion. According to the answers of the students, I try to reach a solution by asking questions like "Your friend says this, do you think it is true? What do we need here? Or what do you think we should do to find it?"

As T2 mentioned, teachers usually project the questions onto the smart board and employ the question and answer technique to reach a solution. T2 states that she asks students several questions to ensure them to understand the problem context and to include them in the solution process. T7, who does not access to a smart board, asserted the adverse effects of the situation with the following words:

T7: ...we cannot print the [the skill-based] question, and it covers all the board if written. The students cannot keep up with that either. The more we try to write the questions, the more we fall 
behind the curriculum...Because it takes at least 10 minutes to write a question on the board. For students it takes their 15 or even 20 minutes. For us to solve, for them to understand... The students look at the board and see a very long question and say that they could never solve it, maybe they will not be so afraid if they solve it on paper. The board frightens more than the paper... We do not have a smart board. It has not yet arrived. Printing is a solution, but there is also a problem about that. We have a classroom size of 50-60 students, after a while, we, as teachers, pay the photocopy fees. It is a burden for us to make copies every day. I am against collecting money from students, I do not do it. That is why I can afford it to a certain extent...One question takes up a page. If you copy at least 10 question, it makes 10 pages. If you copy two pages on one page, they cannot see it, which is another problem.

As T7 stated, the inadequacy of the physical infrastructure of the classrooms, for example the lack of smart boards, negatively affects the in-class use of skill-based questions.

\subsubsection{Views on Curricular Resources Including Skill-Based Questions}

During the interviews, teachers were also asked to express their views on the resources that include skillbased questions. One of the significant findings is that skill-based questions are not included enough in the textbooks provided by MoNE free of charge. Six teachers (T2, T4, T5, T7, T8, T9) working in public schools indicated that the questions in the textbooks are not compatible with the skill-based questions. For instance:
Researcher: How would you evaluate the MoNE's textbook in terms of skill-based questions?
T9: Most of the examples in the MoNE's 8th grade textbook are not related to skill-based questions. The style of the questions in the textbooks and in the exam are not at the same level, but more to reinforce the subject, to teach the subject, more at the curriculum level. The questions asked in the exam are about knowing and interpreting mathematics rather than the curriculum. There is such a contradiction. The textbook is not enough for the exam.

T9 stated that the questions in the textbooks are mostly practice questions for reinforcing the subject and the textbooks are insufficient in terms of skill-based questions. Expressing a similar opinion to T9, T2 pointed out that the students notice the incompatibility between the questions in the textbooks and the questions in the LGS as well. She says:

T2: But there is not even one skill-based question in the textbooks. When this is the case, the students think in this way: "You have to use this textbook at school, you have to follow it. We do not come up with such questions, then why we study these in the class but be exposed to different questions in the exam?" From this point, I can say that there is trouble with the textbooks.

As can be understood from the excerpt above, T2 indicates that the questions in the textbooks are insufficient with the skill-based questions in the LGS and that the students are also aware of this fact.

All teachers stated that they appeal to various resources with skill-based questions to utilize them in the classes, recommend them to their students and for that purpose they analyzed various resources. One of the most common sources used by the teachers is the skill-based question samples that the MoNE publishes every month and the books by private publishers. The teachers consider the sample questions published by MoNE as good examples of skill-based questions and state that they employ them in the class and give them to their students to solve. For instance:

\section{T5: The sample questions published by MoNE are really high quality, very plain, very decent. If you examine the difference between questions of last year and this year you can see that there is a serious improvement.}

In addition to the sample questions of MoNE, all the teachers refer to the books by private publishing companies to reach to the skill-based questions. Since there are many private publishing companies printing these books, it is not probable to reach a single result. However, although the teachers believe that some private publishers have improved in this regard, they state that the quality of the skill-based questions in the sources of many publishing companies is insufficient. The inadequacy of the quality is detailed differently by the teachers. The teachers indicated that the questions issued by private publishing companies are not understandable (T3), might require unnecessary operations (T2), do not qualify as skill-based questions (T1, T3, T5), uncertainty what they measure (T2), the stem of items is long (T6), occasionally may contain errors (T5) and they bear significant resemblance to MoNE's sample questions (T6, T7).

Some of the teachers stated that they also use their own skill-based questions in the class along with the sample questions of MoNE and the books from various publishing companies. T6, who works in a private school, stated that he employs the skill-based questions prepared by the mathematics teacher group in his lessons. 


\subsubsection{Views on the Need for In-Service Professional Training Activities Related to the Skill-Based Questions}

Finally, teachers were asked about their views regarding in-service professional development activities. None of the teachers, except T6 who works in a private school, participated in an in-service training activity on skillbased questions. T6 stated that he participated in an in-service training activity organized by his institution on the assessment and evaluation of skill-based questions.

As most teachers $(n=9)$ pointed out that they need professional support for the skill-based questions, only one teacher (T8) expressed a contrary opinion. Teachers classified the in-service professional development activities they need regarding skill-based questions under different themes. These are; (i) writing skill-based questions (T5, T6), (ii) understanding the nature and purpose of skill-based questions (T5, T7), (iii) teaching strategies for in-class use of skill-based questions (T2, T10), (iv) developing problem solving skills for skill-based questions (T3), and (v) how students perceive the skill-based questions. T5 stated the following in the interview:

T5: I think there is such a need, first, in terms of teachers accepting to solve these new generation questions in the classroom. In addition, in order to set the logic, teachers should be given professional support on issues such as what the PISA logic is, what it is, which questions are included, or not included in this question style. In this sense the academia can help teachers. Scholars and teachers working together, for example, can write such questions...

T5, indicates that an in-service professional training activity is needed to understand the nature and purpose of skill-based questions. T8, who stated that he did not need an in-service training for skill-based questions contrary to T5, explained his views as follows:

T8: No, I do not need it. As I said, we used to do it. We have always had math problems depending on the subject. But now, in every subject, all questions are presented as mathematics problems. On the similarity subject, we would not draw a triangle right away. Telephone and electricity poles would be drawn. There were mathematics problems in that way, we are no stranger, and now they call them as new generation questions.

T8, who has higher years of experience, stated that he considers the skill-based questions as mathematics problems and do not need any support in this regard since he always used them in his lessons in previous years.

\subsection{Teachers' Views on Skill-Based Questions: Quantitative Findings}

The quantitative findings from the questionnaire are grouped into four categories. These categories are: (i) the nature of skill-based questions, (ii) their implementation in mathematics classes, (iii) teachers' views on the curricular resources involving skill-based questions (iv) the needs of teachers for in-service professional training activities. However, to determine whether the teachers recognize the skill-based questions, which are used in the level determination and placement exams, teachers were first asked if they had examined the LGS and PISA questions from previous years. $98.6 \%$ of the teachers (214 persons) stated that they examined the questions of previous years in LGS, and $76.5 \%$ (166 persons) examined the PISA questions.

\subsubsection{Teachers' Views on the Nature of Skill-Based Questions}

Table 4 demonstrates whether the teachers agree with the expressions about the nature of the skill-based questions in the questionnaire prepared based on the qualitative data.

Table 4. Teachers' views on skill-based questions

\begin{tabular}{|c|c|c|c|c|c|c|}
\hline \multirow{2}{*}{ Variables } & \multicolumn{2}{|c|}{ Disagree } & \multicolumn{2}{|c|}{ Undecided } & \multicolumn{2}{|c|}{ Agree } \\
\hline & $\mathbf{n}$ & $\%$ & $\mathbf{n}$ & $\%$ & $\mathbf{n}$ & $\%$ \\
\hline I think skill-based questions are difficult. & 68 & 31.3 & 42 & 19.4 & 107 & 49.3 \\
\hline I think skill-based questions measure higher-order thinking skills. & 13 & 6 & 32 & 14.7 & 172 & 79.3 \\
\hline I approve giving formulas or factual information in skill-based questions. & 24 & 11.1 & 20 & 9.2 & 173 & 79.7 \\
\hline $\begin{array}{l}\text { I think that students who solve many procedural questions will be successful in } \\
\text { skill-based questions. }\end{array}$ & 121 & 55.8 & 57 & 26.3 & 39 & 18 \\
\hline $\begin{array}{l}\text { I think skill-based questions distinguish between students who study and who } \\
\text { do not. }\end{array}$ & 51 & 23.5 & 55 & 25.3 & 111 & 51.2 \\
\hline I think skill-based questions are similar to PISA questions. & 18 & 8.3 & 100 & 46.1 & 99 & 45.6 \\
\hline I think skill-based questions are similar to ALES questions. & 28 & 12.9 & 41 & 18.9 & 148 & 68.2 \\
\hline I think skill-based questions are unnecessary. & 174 & 80.2 & 31 & 14.3 & 12 & 5.5 \\
\hline I think skill-based questions performed better for conceptual learning. & 24 & 11.1 & 50 & 23 & 143 & 65.9 \\
\hline
\end{tabular}

Views regarding the skill-based questions, $49.3 \%$ of the teachers think that skill-based questions are difficult and $79.3 \%$ of them believe they measure higher-order thinking skills. $79.7 \%$ of the teachers approve providing formula or information in skill-based questions. $55.8 \%$ of the teachers do not believe that students who solve many operation-based questions will be successful at skill-based questions, and $51.2 \%$ think that skill-based 
questions distinguish between the students who study and who do not. $46.1 \%$ of the teachers are undecided about the resemblance of the questions to PISA questions, while $45.6 \%$ think that they are similar to PISA questions and $68.2 \%$ to ALES (Selection Exam for Academic Personnel and Graduate Studies). While 80.2\% of the teachers do not agree that the skill-based questions are unnecessary, $65.9 \%$ believe that conceptual learning is achieved better by virtue of these questions.

The analyses of the ranking of the reasons for student difficulties while solving skill-based questions based on the degree of the difficulty are presented in Table 5. According to the teachers, the reasons for students to have difficulty with skill-based questions are respectively, not comprehending what they read $(\bar{X}=2.43)$, insufficient higher-order thinking skills $(\bar{X}=3.25)$, for the question to have long stem $(\bar{X}=3.83)$, poor visual reading skills (table, graphic, figure, etc.) $(\bar{X}=4.47)$, not being accustomed to questions $(\bar{X}=4.57)$, unfamiliarity with the real-life situations in the questions $(\bar{X}=4.62)$ and insufficient mathematical knowledge $(\bar{X}=4.83)$.

Table 5. Descriptive statistics of the reasons for students to have difficulties while solving skill-based questions based on the degree of the difficulty

\begin{tabular}{|c|c|c|c|c|c|c|c|c|c|}
\hline Variables & 1 & 2 & 3 & 4 & 5 & 6 & 7 & $\overline{\boldsymbol{X}}$ & $\widetilde{\boldsymbol{X}}$ \\
\hline The stem of questions are long. & 31 & 31 & 34 & 36 & 38 & 26 & 21 & 3.83 & 4 \\
\hline The student does not comprehend what s/he read. & 88 & 54 & 24 & 20 & 15 & 8 & 8 & 2.43 & 2 \\
\hline $\begin{array}{l}\text { The student is not familiar with the real-life situations } \\
\text { in the questions. }\end{array}$ & 7 & 26 & 37 & 37 & 29 & 27 & 54 & 4.62 & 5 \\
\hline $\begin{array}{l}\text { The student has poor visual reading skills (table, } \\
\text { graphic, figure, etc.) }\end{array}$ & 11 & 23 & 34 & 39 & 35 & 46 & 29 & 4.47 & 5 \\
\hline The student is not accustomed to these questions. & 14 & 21 & 30 & 26 & 47 & 46 & 33 & 4.57 & 5 \\
\hline The student has inadequate mathematical knowledge & 12 & 19 & 22 & 34 & 32 & 50 & 48 & 4.83 & 5 \\
\hline The student has inadequate higher-order thinking skills. & 54 & 43 & 36 & 25 & 21 & 14 & 24 & 3.25 & 3 \\
\hline
\end{tabular}

\subsubsection{Views on the In-class Use of Skill-Based Questions}

The analysis results obtained from the data on how teachers implement skill-based questions in their classroom practices and mathematics exams are demonstrated in Table 6.

Table 6. Descriptive statistics for the use of the skill-based questions

\begin{tabular}{|c|c|c|c|}
\hline \multicolumn{2}{|l|}{ Variables } & \multirow{2}{*}{$\begin{array}{c}\mathbf{n} \\
1\end{array}$} & \multirow{2}{*}{$\begin{array}{c}\% \\
.5\end{array}$} \\
\hline Grade level & I do not use & & \\
\hline & $5^{\text {th }}$ grade & 129 & 59.4 \\
\hline & $6^{\text {th }}$ grade & 149 & 68.7 \\
\hline & $7^{\text {th }}$ grade & 186 & 85.7 \\
\hline & $8^{\text {th }}$ grade & 202 & 93.1 \\
\hline \multirow[t]{3}{*}{ Kind of the mathematics class } & Compulsory mathematics class & 180 & 83.3 \\
\hline & Elective mathematics class & 148 & 68.5 \\
\hline & Courses and/or study lessons at school & 171 & 79.2 \\
\hline \multirow{4}{*}{$\begin{array}{l}\text { Frequency of the use in compulsory and/or elective } \\
\text { mathematic class }\end{array}$} & Every lesson & 36 & 16.7 \\
\hline & Every week & 120 & 55.6 \\
\hline & Biweekly & 35 & 16.2 \\
\hline & Once in a month & 25 & 11.6 \\
\hline \multirow{4}{*}{$\begin{array}{l}\text { The stage of the use in compulsory and/or elective } \\
\text { mathematic class }\end{array}$} & In the introduction of the subject & 14 & 6.5 \\
\hline & Immediately after the lecture & 36 & 16.7 \\
\hline & After solving the exercises on the subject & 155 & 71.8 \\
\hline & At the end of the unit & 145 & 67.1 \\
\hline \multirow[t]{5}{*}{ The use of the questions in mathematics exams } & I do not use & 63 & 29 \\
\hline & At least one in each exam & 83 & 38.2 \\
\hline & In the entire exam & - & - \\
\hline & I decide by subject & 77 & 35.5 \\
\hline & I decide by grade level & 84 & 38.7 \\
\hline
\end{tabular}

The teachers use the skill-based questions mostly in 8th grade $(93.1 \%)$, and in compulsory mathematics classes $(83.3 \%)$. While skill-based questions are commonly used every week $(55.6 \%)$ in compulsory and/or elective mathematics classes, they are mostly applied after the exercises (71.8\%) and at the end of the unit (67.1\%). $38.7 \%$ of the teachers decide to utilize skill-based question in their exams by the grade level and $35.5 \%$ decide by the subject. While $38.2 \%$ of the teachers employ at least one skill-based questions in every exam, $29 \%$ of them employ none.

The analyses of the distributions of teachers' ways of present skill-based questions to their students and the way they use these questions in the class and whether these distributions differ according to the institution the teachers work in are demonstrated in Table 7. 
Table 7. Distribution of the use of skill-based questions in the classroom by the institutions of the teachers.

\begin{tabular}{|c|c|c|c|c|c|c|c|c|}
\hline \multirow{3}{*}{ Variables } & & \multicolumn{6}{|c|}{ The Institution } & \multirow{3}{*}{$\mathbf{p}$} \\
\hline & & \multicolumn{2}{|c|}{ Total } & \multicolumn{2}{|c|}{ State } & \multicolumn{2}{|c|}{ Private } & \\
\hline & & $\mathbf{n}$ & $\%$ & $\mathbf{n}$ & $\%$ & $\mathbf{n}$ & $\%$ & \\
\hline \multirow{3}{*}{$\begin{array}{l}\text { How teachers } \\
\text { present skill-based } \\
\text { questions in the } \\
\text { classroom. }\end{array}$} & I write on the board. & 44 & 20.4 & 33 & 21.7 & 11 & 17.2 & \multirow[t]{3}{*}{.47} \\
\hline & Students are given printed material in front of them. & 154 & 71.3 & 105 & 69.1 & 49 & 76.6 & \\
\hline & I project them onto the screen of smart board. & 171 & 79.2 & 118 & 77.6 & 53 & 82.8 & \\
\hline \multirow{5}{*}{$\begin{array}{l}\text { How teachers use } \\
\text { skill-based questions } \\
\text { in the classroom }\end{array}$} & I give them as homework and check it in the class. & 110 & 50.9 & 72 & 47.4 & 38 & 59.4 & \multirow[t]{6}{*}{.38} \\
\hline & Students study individually. & 109 & 50.5 & 72 & 47.4 & 37 & 57.8 & \\
\hline & Students do group study. & 73 & 33.8 & 50 & 32.9 & 23 & 35.9 & \\
\hline & I have a class discussion. & 139 & 64.4 & 96 & 63.2 & 43 & 67.2 & \\
\hline & I solve students' questions individually. & 127 & 58.8 & 91 & 59.9 & 36 & 56.3 & \\
\hline Total & & 216 & 100 & 152 & 100 & 64 & 100 & \\
\hline
\end{tabular}

While presenting the skill-based questions to the classroom, the teachers mostly prefer to present them on the smart boards $(79.2 \%)$ and to give students printed material with the questions on $(71.3 \%)$. Their least preferred presentation style is writing the question on the board (20.4\%). Teachers' presentation way of skill-based questions does not differ in relation to the institution they work in (p>.05). When the teachers employ the skillbased questions in their classes they prefer respectively to have a class discussion $(64.4 \%)$, to solve students' questions individually $(58.5 \%)$, to give homework and check them in the class $(50.9 \%)$, students to work individually $(50.5 \%)$ and students to study in groups $(33.8 \%)$. Teachers' use of skill-based questions in the classroom does not differ based on the institution they work in $(\mathrm{p}>.05)$.

\subsubsection{The Views on the Curricular Resources Involving Skill-Based Questions}

The data regarding the sources that the teachers prefer when utilizing skill-based questions are demonstrated in Table 8.

Table 8. Distribution of the resources used for skill-based questions.

\begin{tabular}{llcc}
\hline Variables & n & \% \\
\hline The kind of the source & I do not use any resource & 4 & 1.8 \\
& MoNE's monthly published sample questions & 202 & 93.1 \\
& MoNE's textbook & 75 & 34.6 \\
& Books of private publishers & 195 & 89.9 \\
& The questions I prepared myself. & 59 & 27.2 \\
& The questions we prepared as a group & 32 & 14.7 \\
& The questions published by the institution I work for & 18 & 8.3 \\
\hline
\end{tabular}

While implementing the skill-based questions, the teachers mostly prefer the sample questions that MoNE publishes monthly $(93.1 \%)$ and books of private publishers $(89.9 \%)$. The results of the evaluation made by the teachers for three of the most preferred sources when using skill-based question are presented in Table 9.

Table 9. The evaluation of the sources including skill-based questions

\begin{tabular}{|c|c|c|c|c|c|c|c|c|c|}
\hline \multirow[b]{3}{*}{ Variables } & \multicolumn{3}{|c|}{$\begin{array}{l}\text { MoNE's monthly published } \\
\text { sample questions } \\
(n=202)\end{array}$} & \multicolumn{3}{|c|}{$\begin{array}{l}\text { The textbook of MoNE } \\
\qquad(n=75)\end{array}$} & \multicolumn{3}{|c|}{$\begin{array}{l}\text { The books of private } \\
\text { publishing companies } \\
(n=195)\end{array}$} \\
\hline & Not appropri & ndecided & Appropriate & Not appropriate & Undecided & Appropriate & Not appropriate & Undecided & Appropriate \\
\hline & $\begin{array}{c}\mathbf{n} \\
(\%)\end{array}$ & $\begin{array}{c}\mathbf{n} \\
(\%)\end{array}$ & $\begin{array}{c}\mathbf{n} \\
(\%)\end{array}$ & $\begin{array}{c}\mathbf{n} \\
(\%)\end{array}$ & $\begin{array}{c}\mathbf{n} \\
(\%)\end{array}$ & $\begin{array}{c}\mathbf{n} \\
(\%)\end{array}$ & $\begin{array}{c}\mathbf{n} \\
(\%)\end{array}$ & $\begin{array}{c}\mathbf{n} \\
(\%)\end{array}$ & $\begin{array}{c}\mathbf{n} \\
(\%)\end{array}$ \\
\hline Number of questions & $\begin{array}{c}35 \\
(17.3)\end{array}$ & $\begin{array}{c}25 \\
(12.4)\end{array}$ & $\begin{array}{c}142 \\
(70.3)\end{array}$ & $\begin{array}{c}31 \\
(41.3)\end{array}$ & $\begin{array}{c}22 \\
(29.3)\end{array}$ & $\begin{array}{c}22 \\
(29.3)\end{array}$ & $\begin{array}{c}10 \\
(5.1)\end{array}$ & $\begin{array}{c}33 \\
(16.9)\end{array}$ & $\begin{array}{c}152 \\
(77.9)\end{array}$ \\
\hline Variety of questions & $\begin{array}{c}14 \\
(6.9)\end{array}$ & $\begin{array}{c}41 \\
(20.3)\end{array}$ & $\begin{array}{c}147 \\
(72.8)\end{array}$ & $\begin{array}{c}28 \\
(37.3)\end{array}$ & $\begin{array}{c}29 \\
(38.7)\end{array}$ & $\begin{array}{l}18 \\
(24)\end{array}$ & $\begin{array}{c}13 \\
(6.7)\end{array}$ & $\begin{array}{c}38 \\
(19.5)\end{array}$ & $\begin{array}{c}144 \\
(73.8)\end{array}$ \\
\hline The use of visuals & $\begin{array}{c}3 \\
(1.5)\end{array}$ & $\begin{array}{c}16 \\
(7.9)\end{array}$ & $\begin{array}{c}183 \\
(90.6)\end{array}$ & $\begin{array}{l}18 \\
(24)\end{array}$ & $\begin{array}{c}17 \\
(22.7)\end{array}$ & $\begin{array}{c}40 \\
(53.3)\end{array}$ & $\begin{array}{c}10 \\
(5.1)\end{array}$ & $\begin{array}{c}43 \\
(22.1)\end{array}$ & $\begin{array}{c}142 \\
(72.8)\end{array}$ \\
\hline Clarity of questions & $\begin{array}{c}9 \\
(4.5)\end{array}$ & $\begin{array}{c}36 \\
(17.8)\end{array}$ & $\begin{array}{c}157 \\
(77.7)\end{array}$ & $\begin{array}{c}12 \\
(16)\end{array}$ & $\begin{array}{c}17 \\
(22.7)\end{array}$ & $\begin{array}{c}46 \\
(61.3)\end{array}$ & $\begin{array}{c}45 \\
(23.1)\end{array}$ & $\begin{array}{c}89 \\
(45.6)\end{array}$ & $\begin{array}{c}61 \\
(31.3)\end{array}$ \\
\hline Relationship with real-life & $\begin{array}{c}1 \\
(.5)\end{array}$ & $\begin{array}{c}34 \\
(16.8)\end{array}$ & $\begin{array}{c}167 \\
(82.7)\end{array}$ & $\begin{array}{c}7 \\
(9.3)\end{array}$ & $\begin{array}{c}20 \\
(26.7)\end{array}$ & $\begin{array}{c}48 \\
(64)\end{array}$ & $\begin{array}{c}13 \\
(6.7)\end{array}$ & $\begin{array}{c}77 \\
(39.5)\end{array}$ & $\begin{array}{c}105 \\
(53.8)\end{array}$ \\
\hline $\begin{array}{l}\text { The quality of the real-life } \\
\text { situation }\end{array}$ & $\begin{array}{c}5 \\
(2.5)\end{array}$ & $\begin{array}{c}54 \\
(26.7)\end{array}$ & $\begin{array}{c}143 \\
(70.8)\end{array}$ & $\begin{array}{c}8 \\
(10.7)\end{array}$ & $\begin{array}{c}24 \\
(32)\end{array}$ & $\begin{array}{c}43 \\
(57.3)\end{array}$ & $\begin{array}{c}14 \\
(7.2)\end{array}$ & $\begin{array}{c}74 \\
(37.9)\end{array}$ & $\begin{array}{c}107 \\
(54.9)\end{array}$ \\
\hline Difficulty level & $\begin{array}{c}21 \\
(10.4)\end{array}$ & $\begin{array}{c}62 \\
(30.7)\end{array}$ & $\begin{array}{c}119 \\
(58.9)\end{array}$ & $\begin{array}{l}18 \\
(24)\end{array}$ & $\begin{array}{c}21 \\
(28)\end{array}$ & $\begin{array}{c}36 \\
(48)\end{array}$ & $\begin{array}{c}44 \\
(22.6)\end{array}$ & $\begin{array}{c}73 \\
(37.4)\end{array}$ & $\begin{array}{c}78 \\
(40)\end{array}$ \\
\hline $\begin{array}{l}\text { Compatibility to the } \\
\text { learning outcomes of the } \\
\text { curriculum }\end{array}$ & $\begin{array}{c}17 \\
(8.4)\end{array}$ & $\begin{array}{c}19 \\
(9.4)\end{array}$ & $\begin{array}{c}166 \\
(82.2)\end{array}$ & $\begin{array}{c}6 \\
(8)\end{array}$ & $\begin{array}{c}14 \\
(18.7)\end{array}$ & $\begin{array}{c}55 \\
(73.3)\end{array}$ & $\begin{array}{c}24 \\
(12.3)\end{array}$ & $\begin{array}{c}43 \\
(22.1)\end{array}$ & $\begin{array}{c}128 \\
(65.6)\end{array}$ \\
\hline
\end{tabular}


The evaluation of the curricular resources by the teachers demonstrates that MoNE's monthly published sample questions $(70.3 \%)$ and the books of private publishers $(77.9 \%)$ are assumed to be appropriate whereas the rate of approval of the textbook of the MoNE is lower (41.3\%). In terms of the question variety, MoNE's sample questions $(72.8 \%)$ and the books of the private publishing companies (73.8\%) are found appropriate whereas the teachers are undecided $(38.7 \%)$ or do not approve $(37.3 \%)$ MoNE's textbook. In terms of the visual usage, MoNE's monthly published sample questions (90.6\%), the books of the private publishing companies $(72.8 \%)$ and the textbook of MoNE (53.3\%) are qualified appropriate. In terms of the clarity of the questions, MoNE's sample questions $(77.7 \%)$ and the textbook of the MoNE $(61.3 \%)$ are found appropriate, while the teachers do not approve $(21 \%)$ or are undecided $(45.6 \%)$ concerning the books of the private publishing companies. With regard to the relationship of the problem with daily life, MoNE's sample questions $(82.7 \%)$, the textbook of the MoNE (64\%) and the books of the private publishing companies $(53.8 \%)$ are found appropriate. In terms of the problem quality of the real situation, MoNE's sample questions (70.8\%), the textbook of the MoNE (57.3\%) and the books of the private publishing companies (54.9\%) are found appropriate. Regarding the difficulty level of the questions, MoNE's sample questions (58.9\%), the textbook of the MoNE (48\%) and the books of the private publishing companies (40\%) are found appropriate. In terms of the compatibility with the learning outcomes of the curriculum MoNE's sample questions (82.2\%), the textbook of the MoNE $(73.3 \%)$ and the books of the private publishers $(65.6 \%)$ are found appropriate.

\subsubsection{The Views on the Need for In-Service Professional Training Activities Regarding Skill-Based Questions}

The analyses of the distribution of whether the teachers need an in-service professional development activity on skill-based questions or not, on what issues they need training and whether this distribution differs with regard to the institution the teachers work for are demonstrated in Table 10.

Table 10. Distribution of the views on in-service professional development activities regarding skill-based questions

\begin{tabular}{|c|c|c|c|c|c|c|c|c|}
\hline \multirow{3}{*}{ Variables } & & \multicolumn{6}{|c|}{ The Institution } & \multirow{3}{*}{$\mathbf{p}$} \\
\hline & & \multicolumn{2}{|c|}{ Total } & \multicolumn{2}{|c|}{ State } & \multicolumn{2}{|c|}{ Private } & \\
\hline & & $\mathbf{n}$ & $\%$ & $\mathbf{n}$ & $\%$ & $\mathbf{n}$ & $\%$ & \\
\hline \multirow{2}{*}{$\begin{array}{l}\text { The need for in-service training } \\
\text { activities regarding skill-based } \\
\text { questions }\end{array}$} & Yes & 129 & 59.4 & 88 & 57.5 & 41 & 64.1 & \multirow[t]{2}{*}{.37} \\
\hline & No & 88 & 40.6 & 65 & 42.5 & 23 & 35.9 & \\
\hline \multirow{6}{*}{$\begin{array}{l}\text { The subject of the in-service } \\
\text { training activities. }\end{array}$} & Question writing & 105 & 81.4 & 74 & 84.1 & 31 & 75.6 & \multirow[t]{6}{*}{.29} \\
\hline & Improving problem solving skills & 84 & 65.1 & 53 & 60.2 & 31 & 75.6 & \\
\hline & Employing questions in the class & 82 & 63.6 & 56 & 63.6 & 26 & 63.4 & \\
\hline & General briefing about LGS & 40 & 31 & 23 & 26.1 & 17 & 41.5 & \\
\hline & The purpose of the questions & 49 & 38 & 33 & 37.5 & 16 & 39 & \\
\hline & $\begin{array}{l}\text { Evaluation of the available } \\
\text { sources }\end{array}$ & 73 & 56.6 & 50 & 56.8 & 23 & 56.1 & \\
\hline
\end{tabular}

While $59.4 \%$ of the teachers need in-service professional training activities concerning skill-based questions, $40.6 \%$ do not need any training. The topics preferred by the teachers who need in-service training respectively are; (i) writing questions $(81.4 \%)$, (ii) improving problem solving skills $(65.1 \%)$, (iii) implementing these questions in the class (63.6\%), (iv) evaluating the available resources $(56.6 \%)$, (v) the purpose of the questions (38\%), and (vi) general briefing about LGS (31\%).

The analyses of the distributions of teachers' participation in the in-service training activities related to the skill-based question and the subjects of these activities, and whether the distributions differ according to the institution the teachers work in are presented in Table 11.

Table 11. Distribution of participation in professional development activities related to skill-based questions

\begin{tabular}{|c|c|c|c|c|c|c|c|c|}
\hline \multirow{3}{*}{ Variables } & & & & \multicolumn{4}{|c|}{ The Institution } & \multirow{3}{*}{$\mathbf{p}$} \\
\hline & & \multicolumn{2}{|c|}{ Total } & \multicolumn{2}{|c|}{ State } & \multicolumn{2}{|c|}{ Private } & \\
\hline & & $\mathbf{n}$ & $\%$ & $\mathbf{n}$ & $\%$ & $\mathbf{n}$ & $\%$ & \\
\hline \multirow{2}{*}{$\begin{array}{l}\text { The need for in-service training } \\
\text { activities regarding skill-based } \\
\text { questions }\end{array}$} & Yes & 129 & 59.4 & 88 & 57.5 & 41 & 64.1 & .37 \\
\hline & No & 88 & 40.6 & 65 & 42.5 & 23 & 35.9 & \\
\hline \multirow{6}{*}{$\begin{array}{l}\text { The subject of the in-service training } \\
\text { activities. }\end{array}$} & Question writing & 105 & 81.4 & 74 & 84.1 & 31 & 75.6 & .29 \\
\hline & Improving problem solving skills & 84 & 65.1 & 53 & 60.2 & 31 & 75.6 & \\
\hline & Employing questions in the class & 82 & 63.6 & 56 & 63.6 & 26 & 63.4 & \\
\hline & General briefing about LGS & 40 & 31 & 23 & 26.1 & 17 & 41.5 & \\
\hline & The purpose of the questions & 49 & 38 & 33 & 37.5 & 16 & 39 & \\
\hline & $\begin{array}{l}\text { Evaluation of the available } \\
\text { sources }\end{array}$ & 73 & 56.6 & 50 & 56.8 & 23 & 56.1 & \\
\hline
\end{tabular}


While $14.7 \%$ of the teachers participated in an in-service training activity related to skill-based questions, $85.3 \%$ did not participate in any training activity. The teachers who participated in professional development activities, received the training respectively on writing questions $(87.9 \%)$, developing problem solving skills $(63.6 \%)$, the purpose of the questions $(39.4 \%)$, and the use of questions in the classroom (39.4\%), general briefing about LGS (27.3\%) and evaluating available resources $(27.3 \%)$. The teachers' need for in-service training activities related to skill-based questions ( $p>.05)$ and the subjects of the training ( $>.05)$ do not differ based on whether the institutions they work for is a public or private school. The teachers' participation in inservice training activities $(\mathrm{p}<.001)$ and the subjects of the training they participated in $(\mathrm{p}<.001)$ shows a statistically significant difference in relation to whether the teachers work in a public or private school.

Table 12. The views of those participating in an in-service training activities regarding the skill-based questions

\begin{tabular}{lccc}
\hline Variables & & $\mathbf{n}$ & \% \\
\hline The adequacy of the in-service professional development activities & Yes & 14 & 42.4 \\
that the teachers participated in regarding skill-based questions & No & 19 & 57.6 \\
\hline
\end{tabular}

The data demonstrating the views of the teachers who participated in the in-service training activities regarding the skill-based questions are presented in Table 12 . While $42.4 \%$ of the teachers found the in-service professional development activity, they participated in regarding the skill-based questions, sufficient, $57.6 \%$ did not find it sufficient.

\subsection{Comparative Analysis of the Qualitative and the Quantitative Findings}

In this section, the qualitative findings obtained from the interviews and the quantitative data obtained from the questionnaire were compared and reported under above-mentioned four headings.

First, when the findings regarding the nature of the skill-based questions are analyzed, it is understood that the teachers mostly respond positively to the skill-based questions in terms of mathematics education and teaching. In addition, it is observed that the mathematics teachers are aware of the properties (e.g. the use of higher-order thinking skills) that distinguish skill-based questions from traditional questions. Nearly half of the teachers participated in the survey stated that they found skill-based questions difficult whereas all the teachers who are interviewed stated that specifically the students had great difficulty in solutions. The findings obtained both by qualitative and quantitative methods demonstrate that this difficulty is largely arose due to the long textual stems of questions, students' inability to comprehend what they read, and students' inadequate higherorder thinking skills.

Second, teachers' ways of implementing skill-based questions in classes was examined in the study. The findings show that skill-based questions are employed in mathematics classes at all secondary school grades starting from the $5^{\text {th }}$ grade and most frequently at the $8^{\text {th }}$ grade. The findings demonstrating that the teachers employ the skill-based questions mostly at the end of the topics or units, group studies are not preferred in the solution processes, and the questions are of the multiple-choice style, suggest that teachers follow a method similar to traditional question solving. A significant finding regarding the in-class practices is that the physical equipment is effective in enabling questions to be used in classes. The findings of the survey also point out that the percentage of presenting the questions by writing on the board is substantial. This indicates that there might be physical infrastructure deficiencies in both school kinds.

Teachers' views about the curricular resources containing skill-based questions have been another heading included in the findings. What stands out in the qualitative findings is that the teachers find mathematics textbooks insufficient in terms of skill-based questions. The low percentage for the use of the textbook in the questionnaire and the fact that the textbook is qualified mostly insufficient regarding the number of questions supports this finding. The skill-based mathematics questions published monthly by MoNE have been found appropriate by most of the teachers and they use these sample questions as the primary resource. It is seen that fewer teachers utilize the textbooks as a source, and they think that the textbooks are insufficient in terms of the number of skill-based questions. Although the books published by private publishing companies have been one of the most used sources by teachers, it is understood that most teachers believe that the skill-based questions in these books are not appropriate in relation to comprehensibility and the level of difficulty.

Finally, both qualitative and quantitative findings about in-service training activities regarding skill-based questions are in parallel with each other. According to the findings, it is seen that only a small part of the teachers participated in an in-service professional development activity for skill-based questions and more than half of the participants did not consider the training sufficient. From this point of view, it can be assumed that most of the teachers shaped their classroom practices regarding the issue with their own knowledge and past experiences without any professional support. The fact that the teachers apply the skill-based questions in their in-class practices as traditional problem solving and after completing the lecture might be an indicator of this assumption. Although the teachers by any means tried to apply skill-based questions in their classes, they 
pointed out that they needed professional support in this regard. To conclude, skill-based questions have been brought to our agenda in the context of mathematics education with the transition to the LGS system. The interviews and survey outcomes demonstrate that the teachers acknowledge this departure and try to implement such questions in their mathematics classes by any means. However, evidently the teachers need professional support regarding skill-based questions.

\section{Discussion and Conclusion}

Turkey has been periodically reforming and updating the curriculum since 2004 (Aksit, 2007; Özer-Özkan \& Acar-Güvendir, 2018). However, although these updates are based on important philosophical changes in terms of education, they have had hardly any impact on teachers' in-class practices (Aktepe et al., 2015; Duru \& Korkmaz, 2010; Temizöz \& Özgün-Koca, 2008; Zembat, 2010). As an impact of PISA, it is understood that the use of skill-based questions in high-stakes tests such as LGS, has a direct and more impact on teachers' in-class practices compared to the reforms made in the curriculum. The findings obtained from this study, in parallel with the findings of Güler et al. (2019), show that middle school mathematics teachers generally consider skill-based questions positive and appropriate in terms of mathematics education and teaching. It is observed that the majority of the teachers try to apply skill-based questions at varying frequencies such as once a week, after the topic or at the end of the unit, and they include these questions in their exams. The teachers implement these questions intensively at the $8^{\text {th }}$ grade but also at lower grades. The findings indicate that the teachers have been in an effort to develop an understanding of skill-based questions and make them a part of their practice.

On the other hand, the way that the teachers employ the skill-based questions in their classes and other inclass activities that they apply for the skills required by these questions, do not show that the effect of PISA or LGS is positive and in the right direction. During in-class practices, teachers generally use skill-based questions with classroom discussion, individual solution or with question-answer method, and less often with group work. For instance, approximately $20 \%$ of the teachers stated that they tried to solve these questions by writing them on the board. The situation can be explained by the lack of infrastructure such as absence of smart boards, or it can be interpreted as an outcome of the fact that teachers continue to use traditional teacher-centered teaching methods. Similarly, only two teachers among the interviewees mentioned the necessity of in-class activities requiring group works and the use of formative assessment effectively for supporting the active participation of students such as STEM or mathematical modeling applications in order to develop the competencies required by skill-based questions. It is observable that the need for teachers to update their in-class practices, which emerged with skill-based questions, results in numerous problem-solving practices still with teacher-centered, traditional methods.

In parallel with the findings of the studies by Güler et al. (2019) and Erden (2020), the majority of teachers need professional development activities regarding the skill-based questions. At this point, the fact the need for professional development support should be seen as an important opportunity for directing mathematics teachers to adopt student-centered pedagogical approaches in which active learning can be achieved. It is known that large-scale high-stakes tests affect teachers' practices positively or negatively (Smith \& Rottenberg, 1991; Stecher, 2002). Transforming skill-based questions to a natural component of mathematics classes by studentcentered teaching methods, may avert the adverse effects of high-stakes tests on teachers' in-class practices. However, the fact that all the sample questions published by MoNE are multiple-choice items, might be a reason why teachers still do not use the methods that keep students active in their in-class practices. As in PISA, increasing the quality of skill-based questions by utilizing open-ended items, can be a supportive factor for teachers to prefer student-centered teaching methods in their classes. In fact, when asked about the similarity between skill-based questions and PISA questions, more than half of the teachers states that they are undecided or that the questions are not similar (see Table 4).

In-service professional development programs or activities should include student-centered teaching practices and explain how they improve students' skills. In the professional development activities for teachers, topics such as writing skill-based questions, how to apply them in mathematics classes, and what other teaching activities can contribute to students' skills required by those questions, should be included as a priority (Güler et al, 2019; Erden, 2020). That is important in terms of meeting the current needs of teachers and directing their inclass practices correctly.

Middle school mathematics teachers consider the skill-based questions published regularly by MoNE as the most appropriate and referenced source. Most of the teachers evaluated the textbooks in terms of the number and types of the questions, and the books of the private publishers in terms of comprehensibility and difficulty of the questions, as undecided or not appropriate (see Table 9). As far as the teachers' views regarding the curricular materials of skill-based questions are concerned, the resources have become better in terms of quality and variety compared to the initial years. According to the results of the study by Güler et al. (2019), teachers needed to utilize different sources such as ALES and PISA for the reason that there were not enough resources in 2018, when the LGS exam was first held. In the current situation, it is seen that the questions published by MoNE and 
the books by private publishers meet the resource needs of teachers significantly. Specifically, MoNE's monthly published questions are the most respected and guiding source for teachers. Therefore, if MoNE publishes inclass activity samples or open-ended questions in addition to the multiple-choice questions regarding the skills that the skill-based questions required, it might have a positive effect on teachers' in-class activities. However, the fact that there are not sufficient skill-based questions in the textbooks and the inadequacies of the questions in the books of private publishers in terms of comprehensibility, difficulty level, and not having a problem situation in the real-life contexts, demonstrate that the adaptation process is still continuing. Moreover, even though the textbooks do not include sufficient skill-based questions, and majority of teachers utilize these questions in small numbers and infrequently in their exams and in-class practices, the entire LGS exam consists of skill-based questions. This is a clear indicator of the incompatibility between the curriculum and the centralized exam (Erden, 2020). That is an important issue that needs to be investigated in detail in terms of the validity of the LGS exam (Diamond, 2007; Koretz, 2005).

In this study, in line with the views of the teachers, a necessity of a comprehensive analysis study on the quality of the skill-based questions arises. Although the questions are said to measure skills such as problem solving, analytical thinking, interpretation, and reading comprehension, it should be clearly described for teachers and students that which skills are exactly measured. In addition, since the reading comprehension skill has become crucial, skill-based questions seem worth examining in terms of understandability and the use of the Turkish (Turanlı, Kıran, Eş, \& Coşkun, 2017). Moreover, how these skills emerge in the learning of outcomebased curriculum and how they can be dealt with will be another main issue that needs to be studied. A comprehensive analysis of the skill-based questions should be carried out in terms of the authenticity of the contexts used in the questions, the understandability of the questions, their compatibility with the curriculum and various other aspects. Because only the multiple-choice item type is used in LGS and open-ended questions as in PISA are not included, several important skills such as organizing ideas and written expression cannot be measured. Therefore, some improvements, which were planned but could not be carried out earlier, such as the use of open-ended items with skill-based questions in the exams like LGS should be put into agenda again in terms of its potential to positively guide teachers' in- class practices.

\section{Appendix 1. Questionnaire}

You can access the whole questionnaire by using the link or data matrix provided below.

https://drive.google.com/file/d/1L7NaGPdxs69JV1R-Vd2BWrODr18vP2Xb/view?usp=sharing






\section{Beceri Temelli Matematik Soruları: Ortaokul Matematik Öğretmenleri Ne Düşünüyor, Nasil Uyguluyor?}

\section{Giriş}

Geniş ölçekli merkezi sınavlar eğitim öğretim sisteminin değerlendirilmesi, geri bildirim alınması, hesap verilebilirlik sağlaması ve yapılacak reformlara karar verilmesi açısından önemli işlevlere sahiptir (Diamond, 2007; Resnick ve Resnick, 1992). Diğer taraftan, geniş ölçekli merkezi sınavların öğrencileri seçme, yerleştirme ve sıralama gibi özellikleri sebebiyle eğitim sistemi üzerinde öğretmenlerin sınıf içi uygulamalarına kadar olumlu veya olumsuz yönde ciddi etkileri söz konudur (Diamond, 2007; Özer-Özkan ve Acar-Güvendir, 2018; Smith ve Rottenberg, 1991; Stecher, 2002). Merkezi sınavlar, sınav odaklı öğretme uygulamalarının gelişmesi (test tekniği vb.) ve sınavlarda sorulmayan bazı önemli konu ve kazanımların göz ardı edilmesi gibi sonuçlarla eğitim sistemini tahrif edebilmektedir (Baştürk, 2011; Çepni ve Kaya, 2002; Koretz, 2005; Miller, Linn ve Gronlund, 2009; Smith ve Rottenberg, 1991; Stecher, 2002).

Türkiye'de uygulanan merkezi sınavlardan biri 8. sınıfı bitiren öğrencilerin liselere yerleştirilmesinde rol oynamaktadır. Bu sınavlar PISA ve TIMSS gibi uluslararası sınavlardan alınan sonuçların etkisi ve öğretim programının değişmesiyle birlikte çok sık değişikliğe uğramaktadır (Ormanc1, 2019). Türkiye'de liseye geçişte önceki yıllarda Ortaöğretim Kurumları Seçme ve Yerleştirme Sınavı (OKS), Seviye Belirleme Sınavı (SBS) ve Temel Eğitimden Ortaöğretime Geçiş (TEOG) sınavları kullanılmış olup 2018 yılından itibaren ise Liselere Geçiş Sistemi (LGS) merkezi sınavı kullanılmaya başlanmıştır. LGS'ye geçilmesi ile birlikte yeni nesil olarak tabir edilen beceri temelli sorular eğitim sistemimizde yerini almıştır. Uluslararası Öğrenci Değerlendirme Programı (PISA) sınavlarının bir yansıması olarak kullanılmaya başlanan bu beceri temelli sorular (Gürbüz, 2019), öğretmen ve öğrencilerin alışkın olmadıkları ve daha önce karşılaşmadıkları yeni bir durumdur. Öğretmen ve öğrencilerin beceri temelli sorulara alışma ve öğrenme sürecinden geçtikleri görülmektedir (Erden, 2020; Güler, Arslan ve Çelik, 2019). Öğrenciler için hayati önem taşıyan LGS sınavının beceri temelli sorulardan oluşması, ders içeriklerinde ve kaynak kitaplarda bu tür uygulamalara daha sık yer verilmesini gerektirmektedir. Nihayetinde öğrencilerin, eğitim-öğretim hayatları boyunca öğrenmedikleri ve tecrübe etmedikleri bilgi ve beceriler ile değerlendirilmeleri, merkezi sınav ile öğretim programının uyumsuzluğu ve dolayısıyla sınavın geçerliliği bakımından önemli bir sorun teşkil edecektir (Diamond, 2007; Erden, 2020; Koretz, 2005).

2018 yılından itibaren LGS ile gündemimize giren beceri temelli soruların matematik eğitimi ve öğretimi üzerine doğrudan ve dolaylı etkileri araştırılması gereken bir konudur. Öğretmenler açısından bakıldığında beceri temelli sorulara karşı olumlu ya da olumsuz bazı düşünceler geliştirmiş olmaları muhtemeldir. Daha önemlisi, öğretmenlerin bu beceri temelli ölçme-değerlendirme yaklaşımını sınıf içi uygulamalarında kullanıp kullanmadıkları, ne sıklıkta ve nasıl kullandıkları ve mevcut pedagojik alan bilgilerinin yeterli olup olmadığı incelenmesi gereken temel meselelerdir. Öğretmenlerin beceri temelli sorularla ilgili ihtiyaç duydukları profesyonel bilgi ve becerilerin belirlenmesi, daha verimli öğretmen yetiştirme ve hizmet içi eğitim programlarının tasarlanmasına da olanak sağlayacaktır. Dolayısıyla, bu çalışmanın amacı ortaokul matematik öğretmenlerinin "yeni nesil" diye tabir edilen beceri temelli sorular hakkındaki görüşlerini ve bu soru türünün öğretmenlerin sınıf içi uygulamalarına yansımalarını ortaya koymaktır. Çalışmaya yön veren araştırma sorusu ve alt soruları şunlardır:

Ortaokul matematik öğretmenlerinin beceri temelli soruların doğası ve matematik öğrenimi ve öğretimi sürecinde kullanımı hakkındaki düşünceleri nelerdir?
a. Öğretmenlerin beceri temelli soruların doğasına yönelik düşünceleri nelerdir?
b. Öğretmenler beceri temelli soruları derslerinde ne sıklıkla ve nasıl kullanmaktadır?
c. Öğretmenlerinin beceri temelli soruların yer aldığı kaynaklar hakkındaki düşünceleri nelerdir?
d. Öğretmenlerin beceri temelli sorular ile ilgili hizmet içi eğitim faaliyetlerine yönelik düşünceleri nelerdir?

\subsection{Merkezi Sınavlar Eğitim Sistemini Nasıl Etkiliyor?}

Daha önce de ifade edildiği gibi merkezi sınavlar eğitim sisteminin genel durumunu görmek, sistemle ilgili geri bildirim alarak niteliği artırmaya çalışmak ve hesap verilebilirlik açısından önemli görülmektedir (Blazar ve Pollard, 2017; Diamond, 2007; Resnick ve Resnick, 1992). Merkezi sınavlar, öğretmenlerin, okul yönetiminin ve politikacıların hesap verebilirliği bakımından önemli bir işleve sahip olmakla birlikte sadece merkezi sınavlara bağlı bir hesap verilebilirlik mekanizmasının eğitim sisteminin bütünlüğü bakımından uygun olmadığı da ifade edilmektedir (Koretz, 2005; Linn, 2000; Nichols, 2007). 
Merkezi sınavların hem öğrenciler hem de öğretmenler üzerinde psikolojik ve sosyal etkileri bulunmaktadır. Literatürde merkezi sınavların öğrenme çıktılarını artırmadığı gibi, okul derslerine ilginin azalması, sınav kaygısı, arkadaşlarıyla daha az zaman geçirme, aileye karşı sorumlu hissetme ve başarısızlı hissi gibi birçok noktada onları olumsuz etkilediği ifade edilmektedir (Kumandaş ve Kutlu, 2014; Nichols, 2007). Smith ve Rottenberg (1991) bir eğitim-öğretim yılı boyunca klinik mülakatlar ve sinıf gözlemleri kullanarak bir grup öğretmen ile yürüttükleri çalışmada merkezi sınavların olumsuz etkilerini dört temel başlık altında raporlamıştır. Bunlar; (i) öğretmenlerin ne öğreteceğini sınava göre belirleme, testte sorulmayan konu ve kavramları ders içeriğinden çıkarma; (ii) öğretmenlerin öğretim yöntemlerini şekillendirme (örn. test tekniği öğretimi); (iii) öğrencileri seçme ve yerleştirmeye odaklayarak okul düzenini bozma; (iv) düşük puan alma kaygısının öğretmen ve öğrenciler üzerindeki negatif etkisidir.

Merkezi sınavların öğretmenlerin sınıf içi uygulamalarına yön veren önemli unsurlardan biri olduğu bilinmektedir (Çetin ve Ünsal, 2019; Çepni ve Kaya, 2002; Smith ve Rottenberg, 1991; Stecher, 2002). Merkezi sınavların öğretmenleri motive etme, gayretli olma ve yenilikçi öğretim yöntemleri kullanmaya teşvik etme gibi olumlu yönleri bulunmaktadır (Stecher, 2002). Öte yandan, merkezi sınavlar sebebiyle sinav odaklı öğretim ve öğretim programında bulunan konu ve kazanımlardan ziyade sınavda çıkan konulara ağırlık verilmesi gibi eğitim sisteminin hedefleriyle uyumlu olmayan sonuçlar da ortaya çıkmaktadır (Çetin ve Ünsal, 2019; Çepni ve Kaya, 2002; Diamond, 2007; Smith ve Rottenberg, 1991; Stecher, 2002). Merkezi sinavlarda sorulan soruların kapsam ve içeriklerinin öğretim programı ile uyumu, sınavın geçerliliği açısından olduğu kadar öğretmenlerin sınıf içi uygulamalarını doğru veya yanlış yönlendirmesi bakımından da önemlidir (Koretz, 2005). Blazar ve Pollard (2017) ve Koretz (2005) sınav odaklı matematik öğretiminin, öğretmenlerin sorgulama-temelli ve arzulu öğretim uygulamalarını olumsuz etkilediğini göstermişlerdir. Öğrencilerin kaygı düzeyi ve sınavda başarılı olma arzuları, aile ve okul yönetiminin yüksek başarı beklentileri, ders içeriğini oluşturma ve öğretim yöntem-tekniği seçimleri gibi konularda öğretmenlerin özgürce hareket edememelerine sebep olmaktadır (Smith ve Rottenberg, 1991). Ayrıca, öğrencilerin, ailelerin ve yöneticilerin merkezi sınavlardan yüksek beklentileri, öğretmenleri sosyal ve psikolojik olarak da olumsuz etkilemektedir (Çetin ve Ünsal, 2019; Özer-Özkan ve Acar-Güvendir, 2018).

\subsection{Uluslararası Sınavların Eğitim Sistemi Üzerine Etkileri}

PISA ve TIMSS gibi uluslararası değerlendirme sınavları ülkelerin diğer ülkelere göre durumunu ve eksikliklerini belirleyerek reform yapmaya zorlama açısından önemli bir politik unsur oluşturmaktadır (Cantley, 2019; Gürlen, Demirkaya ve Doğan, 2019; TEDMEM, 2017). Nitekim PISA sonuçları birçok ülkenin eğitim sistemini ve eğitim politikalarını derinden etkilemektedir (Breakspear, 2012, 2014; Cantley, 2019; Grek, 2009). Fakat Cantley’e (2019) göre, kullanılan sorular ile birçok becerinin ölçülebilirliği tartışma konusu olduğundan, PISA sonuçlarının matematik eğitimine yönelik yanlış politik kararlar alınmasına sebebiyet verebileceği de bilinmelidir. PISA fen okuryazarlığ 1 , matematik okuryazarlığı, okuma becerileri gibi alanlarda OECD ülkeleri arasında bir kıyaslama yaparak eğitim sistemlerinin niteliğini ortaya koymaktadır. Türkiye matematik okuryazarlığı, fen okuryazarlığı ve okuduğunu anlama temel alanlarında OECD ülkeleri arasında düşük performans göstermektedir (Kabael, 2019; Taş, Arıc1, Ozarkan ve Özgürlük, 2016). PISA 2018 sonuçlarına göre Türkiye'nin ortalaması önceki yıllara göre bir artış göstermesine rağmen her üç alanda da OECD ortalamasının altındadır (Karip, 2020).

PISA ve TIMSS gibi uluslararası değerlendirme sınavlarından ve ulusal çapta yapılan merkezi sınavlardan elde edilen sonuçlar neticesinde Türk eğitim sisteminde de bazı reform faaliyetleri gerçekleştirilmektedir (Aksit, 2007). Bu reform faaliyetleri kapsamında 2004 yılından itibaren bütün kademelerdeki öğretim programlarında öğretmen merkezli didaktik anlayıştan vazgeçilip öğrenciyi merkeze alan, beceri odaklı, biçimlendirici ve alternatif ölçme değerlendirme araçlarını önemseyen bir anlayış benimsenmiştir (Aksit, 2007; Özer-Özkan ve Acar-Güvendir, 2018). Daha sonra 2013 ve 2018 yıllarında ilkokul, ortaokul ve lise öğretim programları revize edilmiştir. Fakat eski alışkanlıkların ve inançların değişime dirençli olması dolayısıyla yenilenen öğretim programlarının öğretmenler tarafindan anlaşılması ve amacına uygun olarak uygulanabilmesi çok kolay olmamaktadır (Duru ve Korkmaz, 2010; Zembat, 2010). Öğretim programlarında yapılan reformların yalnız başına, öğretmenlerin öğretme yöntem ve stratejilerini çok etkilemediği görülmektedir (Diamond, 2007). Sonuç olarak ülkemizde de öğretim programlarında yapılan reformlara rağmen matematik öğretmenlerinin büyük çoğunluğu halen öğrenciyi merkeze alan öğretim yöntemleri yerine düz anlatım yöntemini daha yoğun kullanmayı tercih etmektedir (Aktepe, Tahiroğlu ve Acer, 2015; Temizöz ve Özgün-Koca, 2008).

Eğitimde reform faaliyetleri sadece öğretim programlarının değiştirilmesini değil lise ve üniversiteye geçişte yapılan merkezi sınavların da değiştirilmesini kapsamaktadır. 8. sınıftan itibaren Anadolu ve fen liseleri gibi daha nitelikli okullara yerleşmek için yapılan sınavlarda son 15 yıl içerisinde OKS, SBS, TEOG kullanılmış ve son olarak bu sınav 2017-2018 eğitim-öğretim yılından itibaren LGS ismini almıştır (Ormancı, 2019). Gerçekten de PISA sınavlarının Türk eğitim sistemi üzerine en belirgin etkisinin 2018 y1lından itibaren uygulamaya konulan LGS ve hatta diğer merkezi sinavlarda, önceki yıllardan farklı olarak, bağlamsal ve beceri temelli soruların sayısının artması olduğu söylenebilir (Erden, 2020; Güler ve Ülger, 2019; Gürbüz, 2019). Türkiye'de yapılan merkezi sınavlarda, özellikle matematik alanında, beceri temelli soruların kullanımı dikkat çekmektedir. 


\subsection{Beceri Temelli Sorular}

Yazılı materyal, grafik, tablo, harita, resim veya şema gibi öğelerle desteklenmiş bir bağlam sunulup, bu bağlama yönelik yorumlama, analiz etme, problem çözme, matematiksel muhakeme gibi üst düzey becerileri gerektiren bir dizi objektif veya açık uçlu test maddeleriyle oluşturulan sorular yorumlama alıştırmaları (interpretive exercises) olarak bilinmektedir (Miller ve ark., 2009). Türk eğitim sistemi bağlamında ise bu sorular beceri temelli sorular olarak adlandırılmaktadır. Beceri temelli sorular eğitimcilere, temel objektif madde türleriyle ölçülmesi pek mümkün olmayan üst düzey düşünme becerilerini ölçme olanağ 1 sağlamaktadır. Fakat yüksek düzeyde okuma becerisi gerektirmesi, nitelikli soru üretmenin zorluğu, sosyal-iletişim ve kendini ifade edebilme gibi becerileri ölçmemesi bu soruların zayıf yönleri olarak görülmektedir (Miller ve ark., 2009).

PISA'da kullanılan sorular beceri temelli sorulara iyi birer örnek teşkil etmektedir. PISA matematik okuryazarlığı alanında matematiksel süreçler olarak, (i) problem durumunu matematiksel olarak formüle etme, (ii) matematiksel kavramları, prosedürleri ve düşünmeyi kullanma ve (iii) matematiksel çıktıları yorumlama ve değerlendirme bileşenlerine; her bir sürecin altında ise iletişim, matematikleştirme, temsil, muhakeme, strateji üretme, matematiksel dili ve araçları kullanma yeterliklerine odaklanmaktadır (Kabael, 2019, s.33; OECD, 2018). PISA sorularında ve genel olarak beceri temelli sorularda bağlamın gerçekçiliği ve bağlam çeşitliliği de önemlidir (Güler ve Ülger, 2019; Kabael, 2019). Çepni'ye (2019) göre Türkiye'nin PISA sınavlarında başarıyı yakalayabilmesi için öncelikle öğretim programlarında teorik olarak yer alan becerilerin bağlam temelli olarak ele alınması ve merkezi sınavlarda PISA sorularına yakın bağlam ve beceri temelli sorulardan oluşması gerekmektedir. Nitekim 2018 yılından itibaren uygulamaya konulan LGS matematik bölümünün tamamı beceri temelli sorulardan oluşturulmaya başlanmıştır. Güler ve Ülger'e (2019) göre, kullanılan gerçek hayat bağlamlarının PISA sorularındaki kadar gerçekçi olduğunu söylemek mümkün olmamakla birlikte, LGS beceri temelli sorularının önceki yıllarda sorulan sorulara kıyasla daha üst düzey düşünme becerileri gerektirdiği söylenebilir.

PISA sorularına ilişkin öğretmen, öğretmen adayı veya öğrenci görüş, düşünce ve performanslarını inceleyen birçok çalışma bulunmaktadır (Aydın ve Özgeldi, 2019; İpek ve ark., 2016; Kabael ve Barak, 2016; Radišić ve Baucal, 2018). Kabael ve Barak (2016) tarafından bazı PISA soruları kullanılarak yapılan çalışmada, matematik öğretmen adaylarının matematikleştirme ve dolayısıyla matematik okuryazarlığı bakımından beklenen düzeyin altında kaldıkları görülmüştür. Aydın ve Özgeldi (2019) ise PISA sorularını çözerken matematik öğretmen adaylarının en çok bağlamsal bilgi gerektiğinde veya soru kökünde kullanılan bağlamlara özel matematiksel argümanlar üretmekte zorlandıklarını göstermişlerdir. Radišić ve Baucal (2018) tarafindan yapılan çalışmada ise PISA sorularında öğrencilerin yaşadığı zorlukların sebebine ilişkin olarak matematik öğretmenleri, öğrencilerin bu sorulara aşina olmamalarını ve sınıflarda bu tür soruların kullanılmamasını belirtmişlerdir. PISA soruları özelinde yapılan bu çalışmalar, öğretmen, öğretmen adayı ve öğrencilerin beceri temelli sorulara aşina olmadıklarını ve bu soruların çözümünde zorluklar yaşadıklarını göstermektedir.

Güncel olması dolayısıyla beceri temelli sorulara ilişkin az sayıda çalşsma bulunmakta ve bu çalışsmalar ise beceri temelli sorularla ilgili öğretmen görüşlerine odaklanmaktadır (Güler ve ark., 2019; Erden, 2020). Güler ve arkadaşları (2019) tarafindan yapılan çalışmada, matematik öğretmenleri LGS'de kullanılan beceri temelli soruların niteliğine ilişkin olumlu görüşler belirtmiş̧ler, fakat hem öğrenciler hem kendileri için çok zor olduğunu ve ayrıca bu sorularla ilgili kaynakların yetersiz olduğunu ifade etmişlerdir. Yine, Erden (2020) tarafindan öğretmen görüşlerinin incelendiği çalışmada, Türkçe, matematik ve fen bilimleri öğretmenleri, beceri temelli sorulara ilişkin olarak öğretim programlarının kendilerine yeterince rehberlik etmediğini, kaynakların yetersiz olduğunu ve hizmet içi eğitime ihtiyaç duyduklarını ifade etmişlerdir. Beceri temelli sorularla ilgili öğretmenlerin düşünceleri, yaşadıkları zorluklar, kaynak ve profesyonel destek ihtiyaçları daha kapsamlı olarak araştırmaya değer görünmektedir (Erden, 2020; Güler ve ark., 2019). Bu çalışmanın amacı ortaokul matematik öğretmenlerinin beceri temelli sorulara yönelik görüşlerini, sınıf içi uygulamalarında nasıl uyguladıklarını, bu soruların yer aldığı kaynaklar hakkındaki görüşlerini ve mesleki gelişim ihtiyaçlarını ortaya çıkarmaktır.

\section{Yöntem}

Çalışmada nitel ve nicel araştırma yöntemlerinin bir arada olduğu karma yöntem kullanılmıştır. Karma yöntem araştırmalarının desenleri literatürde farklı isimlendirmelerle karşımıza çıkmaktadır. Bu çalışmada kullanılan desen, literatürde keşfedici ardışık desen (Creswell ve Plano Clark, 2011) ve sıralı karma desen olarak adlandırılmaktadır (Teddlie ve Tashakkori, 2009). Bu desen türündeki (NITEL $\rightarrow$ NICEL) araştırmalarda, bir olguyu incelemek amacıyla önce nitel veriler toplanıp daha sonra nitel veriler arasındaki ilişkileri açıklamak için nicel veriler toplanmaktadır (Creswell ve Plano-Clark, 2011). Bu çalışmada kullanılan araştırma deseni ve akış şeması Şekil 1'de özetlenmiştir. 


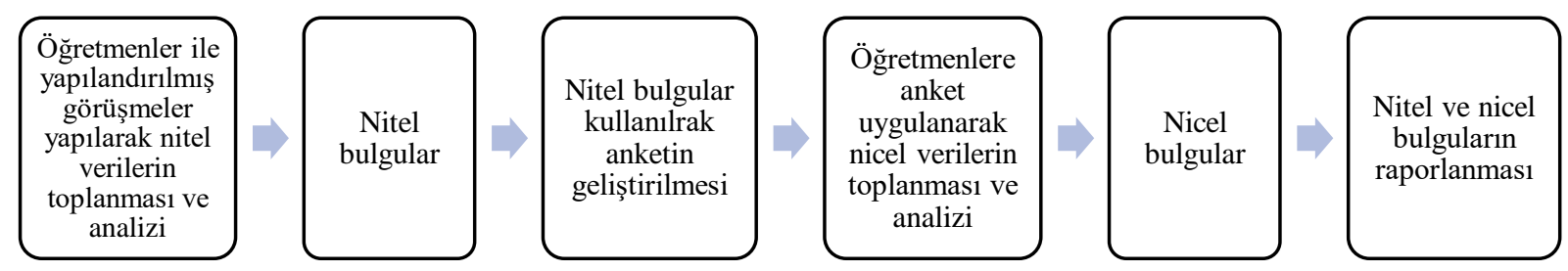

Şekil 1. Çalışmanın akış şeması

Şekil 1'de görüldüğü üzere, çalışmanın amacı doğrultusunda ilk olarak ortaokul matematik öğretmenleri ile yarı yapılandırılmış görüş̧meler yapılarak nitel aşama tamamlanmıştır. Ardından nitel verilerin analizinden elde edilen bulgulardan faydalanılarak nicel aşamada kullanılan anket geliştirilmiştir. Geliştirilen anket İstanbul'da görev yapan ortaokul matematik öğretmenlerine uygulanarak çalışmanın nicel aşaması tarama yöntemiyle tamamlanmıştır. Greene, Caracelli ve Graham (1989) araştırmalarda karma yöntemin farklı gerekçeler ile kullanabildiğini ifade etmektedir. Bu çalışmada, karma yöntem tamamlayıcılık (complementarity) ve geliştirme (development) amacı ile kullanılmıștır. Nitel aşamadan görüşmeler yoluyla elde edilen bulgular temel alınarak nicel veri toplama aracı olan anket geliştirilmiştir. Dolayısıyla burada karma yöntemin geliştirme amacıyla kullanıldığı söylenebilir. Karma yöntemin tamamlayıcılık amacı ile kullanılması neticesinde, nitel ve nicel yöntemler kullanılarak elde edilen bulgular bütüncül bir bakış açısı ile yorumlanmıştır.

\section{1. Çalışma Grubu}

Çalışmanın nitel aşamasına katılan ortaokul matematik öğretmenleri, amaçlı örnekleme yöntemlerinden biri olan kolay ulaşılabilir durum örneklemesi ile gönüllülük esasına göre seçilmiştir (Yıldırım ve Şimşek, 2018). Görüşmeye katılacak olan öğretmenlerin çeşitliliğini sağlamak adına öğretmenlerin çalıştkları okul türünün ve deneyim yılının farklılaşması göz önüne alınmıştır. Ayrıca öğretmenlerin seçiminde en az beş sene öğretmenlik deneyimlerinin olmasına ve son iki yıl içerisinde 8 . sınıf düzeyinde derse girmesine dikkat edilmiştir. Görüşme yapılan öğretmenlerde en az beş yıllık deneyim aranmasının sebebi LGS'den önceki yıllarda yapılan TEOG gibi sınavlarda yer alan soru türüne aşina olmaları ve bu sınava girecek olan öğrencilere öğretmenlik yapmalarıdır. Çalışmada ortaokulda matematik öğretmeni olarak görev yapan toplam 10 kişi ile görüşme yapılmıştır. Öğretmenlerin demografik özellikleri Tablo 1'de sunulmuştur.

Tablo 1. Görüşmeye katılan matematik öğretmenlerinin demografik bilgileri

\begin{tabular}{llcc}
\hline Öğretmen & Cinsiyet & Deneyim Yılı & Okul türü \\
\hline T1 & Kadın & 5 & Özel \\
T2 & Kadın & 5 & Devlet \\
T3 & Kadın & 5 & Devlet \\
T4 & Erkek & 12 & Devlet \\
T5 & Erkek & 10 & Devlet \\
T6 & Erkek & 13 & Özel \\
T7 & Kadın & 5 & Devlet \\
T8 & Erkek & 10 & Devlet \\
T9 & Kadın & 28 & Devlet \\
T10 & Erkek & 11 & Özel \\
\hline
\end{tabular}

Çalışmanın nicel aşamasına kolay ulaşılabilir (uygun) örnekleme yöntemi kullanılarak seçilen İstanbul ilindeki Milli Eğitim Bakanlığına bağlı ortaokullarda matematik öğretmeni olarak görev yapan 217 öğretmen katılmıştır. Kolay ulaşılabilir örnekleme yönteminde katılımcıların gönüllü olması veya sadece orada olduğu için çalışmaya katılması beklenir. Gönüllü katılımcılar çalı̧̧maya daha motive olmuş ve daha ilgili olabilecekleri için gönülsüz olanlardan farklıdır (Gay, Mills ve Airasian, 2006). Ankete katılan öğretmenlerin dağılımı Tablo 2'de yer almaktadır.

Nicel aşamada çalışmaya katılan ortaokul matematik öğretmenlerinin \%62,7'si kadın; \%37,3'ü erkektir. Öğretmenlerin \%70,5'i devlet okullarında çalışırken \%29,5'i MEB'e bağlı özel okullarda çalışmaktadır. Bu oran Milli Eğitim Bakanlığının (2019) 2018-2019 eğitim-öğretim yılına raporunda yer alan İstanbul'da ortaokul düzeyinde çalışan öğretmen sayılarındaki oranı yansıtmaktadır. Öğretmenlerin \%19,9'u 1-5 yıl; \%55,8'i 6 - 10 yıl; \%13,4’ü $11-15$ yıl ve $\% 10,1$ 'i 16 - 20 yıl arasında tecrübeye sahiptir. 21 ve üstü yıl çalışan öğretmen bulunmamaktadır. Stajyer öğretmen sayısının $(\% 0,9)$ az olmasının sebebi son yıllarda İstanbul'a KPSS ile atama yapılmaması olarak görülebilir. Beceri temelli soruların kullanılmaya başladığı yıldan itibaren öğretmenlerin \%59,7'si 5. sınıf; \%71,1'i 6. sınıf; \%74,1'i 7. sinıf ve \%83,1'i 8. sinıf düzeyinde ders vermektedir. 
Tablo 2. Ankete katılan matematik öğretmenlerinin demografik özelliklerine göre dağılımları

\begin{tabular}{llll}
\hline Değişkenler & & $\mathbf{n}$ & $\mathbf{\%}$ \\
\hline Cinsiyet & Kadın & 136 & 62,7 \\
& Erkek & 81 & 37,3 \\
\hline Çalışmakta olduğu kurum & Devlet & 153 & 70,5 \\
& Özel & 64 & 29,5 \\
\hline Deneyim yılı & Stajyer öğretmen (1 yıldan az) & 2 & 0,9 \\
& $1-5$ yıl & 43 & 19,9 \\
& $6-10$ yıl & 121 & 55,8 \\
& $11-15$ yıl & 29 & 13,4 \\
& $16-20$ yıl & 22 & 10,1 \\
\hline $2018-2019$ eğitim-öğretim yılından itibaren & 21 ve üstü & - & - \\
derse girdiği sinıf düzeyi & 5. sinıf & 120 & 59,7 \\
& 7. sinıf & 143 & 71,1 \\
& 8. sinıf & 149 & 74,1 \\
\hline
\end{tabular}

\subsection{Veri Toplama Araçları}

Çalışmada nitel verileri toplama aracı olarak yarı yapılandırılmış görüşme formu, nicel verileri toplama aracı olarak ise araştırmacılar tarafından geliştirilen anket kullanılmıştır. Yarı yapılandırılmış görüşme formunda çalışmanın amacına yönelik hazırlanmış açı uçlular soru yer almaktadır. Görüşmelerde öğretmenlere beceri temelli sorular ve bu tür soruların matematik eğitim ve öğretiminde yeri hakkındaki görüşleri sorulmuştur. Bunun yanı sıra, yöneltilen sorular ile matematik derslerinde beceri temelli soruları nasıl kullandıkları açığa çıkarılmaya çalışılmıştır. Ayrıca öğretmenlere beceri temelli soruların yer aldığı kaynaklar (matematik ders kitabı, örnek olarak yayımlanan beceri temelli sorular, özel yayınevleri tarafindan basılan kitaplar) hakkında ne düşündükleri de sorulmuştur. Bu konudaki hizmet içi eğitim faaliyetlerine olan ihtiyaçlarını ortaya çıkarmak için daha önce bu türde bir eğitime katılıp katılmadığ1, ihtiyaç duyup duymadığı, ihtiyaç duyuyor ise bu eğitim içeriğinin ne olduğu hakkında bilgi alınmaya çalışılmıştır. Görüşme formu oluşturulduktan sonra iki matematik öğretmeni ile pilot görüşme yapılmıştır. Pilot çalışma sonrasında gerekli değişiklikler yapılarak forma nihai hali verilmiştir. Pilot çalışmadaki görüşmelerin verileri çalışmada raporlanmamıştır.

Çalışmanın nitel aşamasına 10 matematik öğretmeni ile yarı yapılandırılmış görüşmeler yapılmıştır. Görüşme verilerinin analizinden elde edilen bulgular yardımıyla nicel aşamada kullanılan anket geliştirilmiştir. Nitel verilere ait bulgulara ve araştırma sorularına uygun olarak anketin toplamda dört bölümden oluşmasına karar verilmiştir. Bu bölümler; (i) beceri temelli soruların doğasına, (ii) beceri temelli soruların derslerde kullanımına ve (iii) beceri temelli soruların yer aldığı kaynaklara ve (iv) beceri temelli sorularla ilgili hizmet içi eğitim faaliyeti gereksinimlerine yönelik öğretmen görüşlerini kapsamaktadır.

Anketin ilk bölümünde soruların doğası hakkında öğretmen görüşlerini yansıtan dokuz ifade yer almaktadır. Bu dokuz ifade nitel bulgulardan elde edilmiştir. Öğretmenlerden verilen ifadelerin görüşlerini ne derecede (3'lü likert) yansıttığını seçmeleri istenmiştir. Görüşmelerde tüm öğretmenler, öğrencilerin beceri temelli sorularda zorlandığını ifade etmiş ve bu zorluğu farklı sebeplerle ilişkilendirmiştir. Bu bulgu üzerine anketin ilk bölümüne öğrencilerin beceri temelli sorularda zorlanma nedenleri ile ilgili bir madde eklenmesine karar verilmiștir. Bu maddede öğrencilerin beceri temelli sorularda zorlanmalarına dair yedi gerekçe verilmiş ve öğretmenlerden bu yedi gerekçeyi en çok önemliden en aza doğru sıralamaları istenmiştir. Görüşmelerde öğretmenlerin beceri temelli soruları derslerinde nasıl kullandıklarına yönelik ortaya çıkan kategoriler temel alınarak, bu soruları derslerde nasıl kullanıldığına dair genel eğilimi görmek için anketin ikinci bölümüne toplam yedi madde yazılmıştır. Görüşmelerde, öğretmenlerin beceri temelli soruların yer aldığı farklı türde kaynakları kullandığ 1 ortaya çıkmıştır. Bu sebeple, anketin üçüncü bölümünde ilk olarak öğretmenlere hangi kaynağı kullandıkları sorulmuş ve kullandıkları kaynakları ayrı ayrı sekiz kıstasa (soru çeşitliliği, soruların anlaşılırlığı vb.) göre değerlendirilmesi istenmiştir. Anketin son bölümü ise beceri temelli sorular ile ilgili hizmet içi eğitim faaliyetleri hakkındadır. Görüşmelerde öğretmenlerin hizmet içi eğitim faaliyetine ihtiyaç duyduğu ortaya çıkmıştır. Bu sebeple ankette hizmet içi faaliyete ihtiyaç duyup duymadığı, ihtiyaç duyuyor ise bu faaliyetin hangi konuda olduğu sorulmuştur. Hizmet içi faaliyetlerin türü toplamda altı başlık altında toplanmıştır. Hizmet içi eğitim faaliyetine katıldı̆̆ını belirten öğretmenlerden ise öncelikle faaliyetin hangi konu üzerine olduğunu belirtmesi ve bu eğitimi yeterli bulup bulmadı̆̆

Anket oluşturulduktan sonra bir dil uzmanı tarafından dilin uygunluğu kontrol edilmiş ve kapsam geçerliliğini belirlemek adına matematik eğitimi alanında çalışan beş uzmanın görüşüne başvurulmuştur. Uzmanlar ankette yer alan her maddeyi belirlenen 10 ölçüte göre değerlendirmiştir. Bu ölçütler maddenin dili, anlaşılırlığı, konu ile ilgisi, kapsayıcılığı ve tutarlığı hakkındadır. Ayrıca uzmanların kendi görüşlerini de 
belirtebilmeleri için eklemek istedikleri bir şey olup olmadığı sorulmuş ve bu görüşler dikkate alınarak anketin son hali verilmiştir. Puanlayıcılar arası uyum için Krippendorff’s Alpha katsayısı kullanılmış ve 0,82 olarak hesaplanmıştır. Uzman görüşlerine dayanan öneriler doğrultusunda yapılan değişikliklerden sonra İstanbul dışında çalışan 18 ortaokul matematik öğretmenine pilot uygulama yapılmıştır. Pilot uygulama sonucunda anketin doldurulma süresi ve çevrimiçi uygulamada meydana gelebilecek aksaklıklar belirlenmeye çalışılmıştır. Pilot uygulamadan sonra gerekli düzenlemeler yapılmış ve anket uygulamaya hazır hale getirilmiştir (Ek 1).

\subsection{Verilerin Toplanması ve Analizi}

Yarı yapılandırılmış görüşmeler, öğretmenin tercihine göre yüz yüze olarak veya çevrimiçi platformlar kullanılarak yürütülmüştür. Görüşmeler 15-20 dakika arası sürmüş olup katılımcının izni alınarak kayıt altına alınmıştır. Deşifre edilen görüşme kayıtlarına içerik analizi yapılmıştır. İçerik analizi ile öğretmenlerin görüşleri birbirine benzer kavram ve temalar çerçevesinde bir araya getirilerek ve yorumlanarak raporlanmıştır (Yıldırım ve Şimşek, 2018). Görüşmelerden elde edilen verilerin analizi (i) soruların doğası, (ii) sınıf içi uygulamalar, (iii) kaynaklar ve (iv) hizmet içi eğitim faaliyetleri olmak üzere dört ana tema göz önünde bulundurularak yapılmıştır. Soruların doğası teması altında beceri temelli sorular üzerine görüşler, öğrencilerin zorlanma nedenleri ve öğrencilerin zorlanmalarının sonuçları olmak üzere üç kategori ve bunların altında kodlar oluşturulmuştur. Beceri temelli soruların sınıf içi uygulamaları teması altında ise derslerin türü ve derslerde kullanım türü olarak iki kategori yer almaktadır. Üçüncü tema olan kaynaklar için kullanılan kaynağın türü ve kaynaklarda yer alan soruların özellikleri olarak iki kategori ortaya çıkmıştır. Son olarak hizmet içi eğitim faaliyetleri altında hizmet içi eğitime katılıp katılmama, katıldığı faaliyetin türü, hizmet içi eğitime ihtiyaç duyup duymama ve ihtiyaç duyulan faaliyetin türü olmak üzere dört kategori ve alt kodları oluşturulmuştur. Her bir tema altında elde edilen kategoriler ve kodlar iki araştırmacı tarafından oluşturulmuştur. Ardından iki araştırmacı rastgele seçilen bir görüşmeyi ayrı ayrı analiz etmiştir. Bu iki analizde araștırmacılar arası uyum \%85 olarak hesaplanmıştır (Miles ve Huberman, 1994). Geri kalan dokuz görüşme ise tek bir araştırmacı tarafından analiz edilmiştir.

Araştırmanın nicel boyutunda kullanılan anket, İstanbul'da çalışan ortaokul matematik öğretmenlerine çevrimiçi olarak iletilmiştir. Anketin uygulanması yaklaşık olarak 9 dakika sürmektedir. Uygulanan anket verilerinde öğretmen görüşlerinin dağılımını belirlemek amacıyla frekans ve yüzde hesaplanmış ve bazı sorularda çalıştıkları kuruma göre farklılık olup olmadığını belirlemek için ki-kare testi kullanılmıştır. Öğretmenlerden sıralama yapmaları istenilen maddelerin analizinde ortalama ve medyan değerlerden yararlanılmıştır.

\section{Bulgular}

Matematik öğretmenlerinin beceri temelli sorular hakkındaki görüşleri üzerine elde edilen bulgular üç bölümde okuyucuya sunulmuştur. İlk olarak görüşmelerden elde edilen nitel, sonrasında ise anketten elde edilen nicel bulgulara yer verilmiştir. Son olarak her iki türdeki bulgular karşılaştırılmalı olarak analiz edilmiştir.

\subsection{Beceri Temelli Sorulara Yönelik Öğretmen Görüşleri: Nitel Bulgular}

Görüşmelerden elde edilen nitel bulgular araştırma sorularına da uygun olarak, (i) beceri temelli soruların doğasına yönelik öğretmen görüşleri, (ii) matematik derslerinde kullanımına yönelik öğretmen görüşleri, (iii) kaynaklara yönelik öğretmen görüşleri ve (iv) hizmet içi eğitim faaliyetlerine duyulan gereksinime yönelik görüşler olmak üzere dört alt başlıkta sunulmuştur.

\subsubsection{Beceri Temelli Soruların Doğasına Yönelik Öğretmen Görüşleri}

Görüşmelerde öğretmenlere beceri temelli sorular hakkındaki düşünceleri ve soruların doğasına yönelik görüşleri sorulmuştur. Bulgular öğretmenlerin çoğunlukla beceri temelli soruları matematik eğitimi ve öğretimi açısından olumlu gördüğünü göstermektedir. Öğretmenlerin beceri temelli soruların doğasına yönelik görüşleri Tablo 3'te sunulmuştur.

Tablo 3. Öğretmenlerin beceri temelli soruların doğasına yönelik görüşleri

\begin{tabular}{ll}
\hline Kodlar & Öğretmenler \\
\hline Üst düzey düşünme becerilerini ölçer. & T1, T3, T5, T6, T7, T8, T10 \\
Okuma becerisi ile ilişkilidir. & T3, T6, T7, T8, T9 \\
Ezberden ziyade bilgiyi kullanmayı gerektirir. & $\mathrm{T} 2, \mathrm{~T} 3, \mathrm{~T} 5, \mathrm{~T} 7$ \\
Günlük hayat durumları ile ilişkilidir. & $\mathrm{T} 5, \mathrm{~T} 7, \mathrm{~T} 8$ \\
Matematik ve disiplinler arası ilişkiyi gerektirir. & $\mathrm{T} 3$ \\
\hline
\end{tabular}

Tablo 3'te görüldüğü üzere öğretmenler beceri temelli soruların doğasına yönelik farklı görüşler dile getirmiştir. $\mathrm{Bu}$ görüşler doğrultusunda öğretmenlerin beceri temelli soruları matematik eğitiminde 
alışageldiğimiz alıştırma tarzı sorulardan farklı nitelendirdiği söylenebilir. Öğretmenler beceri temelli soruların doğasına yönelik olarak; beceri temelli soruların (i) üst düzey düşünme becerisi ölçtüğünü, (ii) okuma becerisi gerektirdiğini, (iii) günlük hayat durumları ile ilişkili olduğunu ve (iv) bilgiyi kullanabilmeyi gerektirdiğini ifade etmişlerdir.

Öğretmenler soruların doğasına yönelik görüşlerini belirtmenin yanı sıra, soruların matematik eğitimindeki yansımalarından da söz etmiștir. Bunlardan en önemlisi öğrenci boyutundadır. Öğretmenlerin tümü öğrencilerin beceri temelli soruları çözerken zorlandığını ifade etmiştir. Hatta öğretmenlerin bir kısmı (T1, T2, T3, T5, T6, T7) öğrencilerin yanı sıra kendilerinin ya da diğer meslektaşlarının da benzer şekilde zorluk yaşayabildiğini ifade etmiştir. Örneğin T3 kodlu öğretmen şunları söylemiş̧ir:

\begin{abstract}
T3: Aslında biz ögretmenler [beceri temelli soru] gördüğümüzde kötü oluyoruz. İlk bakttğımızda anlayamiyoruz. Anlamak için 1-2 dakika gerekiyor. Öğrenciler oradan hocam siz anlayamıyorsunuz iki dakikada biz nasıl çözeceğiz diyor. Çünkü biz de öyle bir öğretimle yetişmediğimiz için zorlanabiliyoruz... Meslektaşlarım da 8. sınıf sorularının çok zor olduğunu söylüyor. Tabii ki çözülebilir ama biz matematik öğretmeni olduğumuz halde tedirgin yaklaşıyoruz soruya, uzunmuş diye geriye çekiliyoruz ama ögrenciler kat be kat bunu yaşlyorlar.
\end{abstract}

Alıntıdan da anlaşıldığı üzere, T3 kodlu öğretmen beceri temelli soruları çözerken öğrencilerin olduğu kadar öğretmenlerin de zorlanabildiğini dile getirmiştir. Öğretmenler, beceri temelli soruları çözerken öğrencilerin yaşadığı zorlukların farklı sebeplerden kaynaklandığını düşünmektedir. Öğretmenlere göre bu sebeplerden ilki öğrencilerin beceri temelli soru tarzına ve soru çözümünde gereken üst düzey düşünme becerilerini kullanmaya alışık olmamalarıdır (T2, T3, T4, T5, T7, T10). Bu öğretmenlerden biri olan T5, bu konudaki düşüncesini aşağıdaki sözler ile açıklamıştır:
T5: Öğretmen ve ögrrencilerimiz bu düşünce tarzına alışkın olmadıkları için zorlanıyorlar. Çünkü eskiden TEOG'da nasll soruluyordu, " $2 x=8$, $x$ nedir?". Fakat şimdi yeni soru tarzlarında böyle bir şey mümkün değil. Şimdi bu bilgiyi bilmen gerektiği gibi bunu nerede, ne zaman, hangi aşamada veya bu bilgiyi mi başka bilgiyi mi kullanacaksın, bunları düşünmeniz gerekiyor. Bizim öğrenciler de düşünmeyi çok sevmediklerinden, haliyle zorlaniyorlar. Düşünmeye alışık olmadıkları için zorlaniyorlar. Aslında burada ince bir nokta var, ögrenciler yapamadıkları için değil alışık olmadıkları için zorlaniyorlar.

T5 kodlu öğretmen, öğrenciler beceri temelli soruların çözümlerinde gereken üst düzey düşünme becerilerine alışık olmadıklarından dolayı zorlandıklarını ifade etmiştir. T5 burada öğrencilerin bu soruları yapabilme potansiyelinin olduğunu ve sınıf içi uygulamalarla bunun ortaya çıkarılabileceğini vurgulamaktadır. Öğretmenlere (T2, T3, T7, T8) göre bir diğer zorlanma sebebi ise beceri temelli sorularda soru kökünün uzun olması ve öğrencilerin bu uzun metinde okuduğunu anlamamasıdır. T2 kodlu öğretmen ise, diğer öğretmenlerden farklı olarak, zorlanma nedeninin öğrencilerin soruda verilen bilgiyi nerede ve nasıl kullanacağını bilmemesi olduğunu düşünmektedir.

Öğretmenler, öğrencilerin beceri temelli soruları çözerken zorlanmalarının farklı sonuçlar doğurduğunu düşünmektedir. Bu sonuçlardan ilki öğrencilerin yaşadıkları zorluklar sonucunda matematiğe ve beceri temelli sorulara karşı olumsuz tutum geliştirmeleridir (T1, T2, T3, T4, T7, T8, T9, T10). Bununla ilgili olarak, T4 kodlu öğretmen şunları ifade etmiştir:
T4: Öğrenciler bu sorularla karşılaş̧t̆ğ zaman olumsuz düşünceler geliştiriyorlar. Ben zaten bu matematiği yapamam, matematik buysa ben yokum gibi... Yapanlar da var, bir şeyler yapmaya çalışanlar da var ama çok başarılı olamiyorlar.

T4'e göre beceri temelli soruları çözerken yaşanan zorluk ile beraber öğrenciler beceri temelli sorulara ve matematik dersine karşı olumsuz bazı tutum ve düşünceler geliştirebilmektedir. T1 kodlu öğretmen T4'e benzer şekilde öğrencilerin zorlandığını ve olumsuz tutum geliştirdiğini düşünmekle birlikte, matematik başarısı yüksek öğrencilerin bir süre sonra bu tip soruları çözmekten keyif aldığını ifade etmiştir. T1 kodlu öğretmen haricinde, öğretmenlerden hiç biri öğrencilerin beceri temelli sorulara karşı olumlu tutum sergilediğini ifade etmemiştir.

Ortaya çıkan bir diğer sonuç ise öğretmenler tarafından akademik olarak düşük ve orta başarı seviyesinde değerlendirilen öğrencilerin beceri temelli soruları çözerken daha fazla zorlandığıdır. Öğretmenlerin ifadesiyle, beceri temelli sorularla yapılan ölçme-değerlendirme, sınıfta akademik başarı olarak orta düzeyde olan öğrencileri de düşük başarı seviyesi kategorisine düşürmektedir (T1, T7, T9, T10). Örneğin T7 kodlu öğretmen şunları ifade etmiştir:

T7: Ben ve diğer meslektaşlarım şu anlamda şikâyetçiyiz biraz. Yeni nesil sorular ile beraber biz, orta seviyedeki ögrrencileri kaybettik aslında. Çünkü iyi [akademik başarısı yüksek] çocuk zorlanıyor ama çalışıp yapmaya çalışıyor. Zayıf [akademik başarısı düşük] olan TEOG'ta da yapamıyordu, şimdi de yapamıyor. Bu ögrrenciler onu çok dert etmiyorlardı zaten. Orta seviyedeki 
ögrrenci, birazcık da olsa uğraşan o öğrenci artık yok. Durumu iyi olanlar ve durumu kötü olanlar var. Orta seviyedeki ögrenciler ben zaten yapamıyorum ki durumunda.

T7'nin düşük ve orta başarı seviyesindeki öğrenciler için ifade ettiği bu zorlanma ve kayıp olma durumu, bazı öğretmenler tarafindan LGS ile ilişkilendirilmiştir. T6 ve T9, LGS'nin tüm öğrencilere değil de sadece belirli bir kesim öğrenciye hitap ettiğini düşünmektedir. T6 bu düşüncesini aşağıdaki sözler ile ifade etmiştir:

T6: MEB \%10'luk kisma yapıyor bu sinavl, yani bütün Türkiye'ye yapmiyor. Ben okulun \%20'sini alıp sınavl yaptığımda net ortalamam 16-17 gibi. Okulun tamamına yaptığımda net ortalaması 6-7 gibi çıklyor. Çok ciddi fark var. Bu sinav genele yapılan bir sinav değil.

T6 kodlu öğretmen hem öğrencilerin sınavdaki başarı farkından bahsetmiş hem de bu sınavın özellikle başarılı öğrencilerine hitap ettiğini ifade etmiştir. Orta ve düşük başarı seviyesindeki öğrencilerin matematik dersinden kopmaması adına T1 ve T10 kodlu öğretmenler, LGS'de sadece beceri temelli soruların yer almaması gerektiğini ve alışageldik, geleneksel sorulara da yer verilmesi gerektiğini ifade etmiştir.

\subsubsection{Beceri Temelli Soruların Derslerde Kullanımına Yönelik Görüşler}

Yapılan görüş̧melerde öğretmenlere beceri temelli soruları matematik derslerinde nasıl kullandıkları sorulmuştur. Dikkat çekici olan bulgulardan biri öğretmenlerin birçoğunun (T1, T2, T3, T4, T5, T8, T10) konu anlatımını bitirip, alıştırma tarzındaki soruları çözüldükten sonra beceri temelli sorulara derslerinde yer vermesidir. Başka bir deyişle öğretmenlerin bu tür soruları derslerinde çeşitli şekillerde uygulanabilecek birer etkinlik olarak değil de daha çok geleneksel soru çözümü şeklinde uygulamaya çalıştıkları görülmektedir. Geleneksel soru çözümü yapan T2, bu uygulamanın çok verimli olmadığını aşağıdaki sözler ile ifade etmiştir:

T2: Bunun nasıl öğretileceği konusunda sıkıntılar var. Bir ögretmen ne yapsa da o sorular ögrenciler tarafindan daha kolay anlaşılsa... Bir tanesini [soru çözümü] anlattyorsun, anlayıp çözüyorlar çok güzel. Birazcık farklı olduğu zaman yine yeniden başa dönüyorsun... Bir gelişme olmuуor.

T2 kodlu öğretmen sadece soru çözümü yaparak öğrencilerin performansını artırmanın mümkün olmadığını, fakat bunun için ne yapması gerektiğini tam olarak bilmediğini ifade etmiştir. Beceri temelli soruların gerektirdiği becerileri geliştirmek için, örneğin proje çalışmaları, grup veya ekip çalışması gerektiren modelleme veya STEM etkinlikleri gibi uygulamalardan sadece iki öğretmen (T5, T6) bahsetmiş̧tir. Örneğin T5, "Bir modelleme etkinliği yapılsa sınıfta öğrencilerin düşünme becerisine çok daha faydalı olacağını düşünüyorum. Ben kendim en azından kullanıyorum.” demiş̧tir. Bu bulgu bizlere çoğu öğretmenin, öğrencilerin performansını arttırmanın çok sayıda beceri temelli soru çözmekten geçtiğine inandığını düşündürmektedir. Benzer bir düşünce T10 tarafından şöyle dile getirilmiştir.

T10: [LGS] üst düzey becerileri ölçen bir sinav ama burada slkıntı şu ki biz bu üst düzey becerileri yine soru çözerek vermeye çalışıyoruz... Programın içerisinde maalesef o becerileri kazandırmaya yönelik hamleler olmazken çocuklardan bunu beklemek... Yani soru çözerek bunları kazandırmaya çalışlyoruz... Sinava hazırlamak bir sonuçtur ama bizde hedef.

T10 kodlu öğretmen beceri temelli sorularla ölçülmeye çalışlan becerilerin yine bu sorulardan çok sayıda çözerek verilmeye çalışılmasının yanlış olduğunu ifade etmektedir. T10'a göre burada asıl hedef, öğrencilere üst düzey düşünme becerilerini kazandırmak değil LGS'ye hazırlamaktır. Bu sonuç LGS'nin öğretmen uygulamaları üzerine olumsuz etkilerinin en belirgin göstergelerinden birisidir.

Öğretmenler (T1, T3, T4, T7, T9) bu tür soruları özellikle seçmeli matematik derslerinde ve okul tarafindan düzenlenen matematik kurslarında yer verdiklerini ifade etmiştir. Bu durumun ilk sebebi zorunlu derslerde genellikle matematik öğretim programını tamamlamak amacıyla konu anlatımının yapılması ve alıştırma tarzındaki soruların çözülmesidir. Örneğin T7 kodlu öğretmen dönemin başında zorunlu derslerde beceri temelli soruların çözümüne vakit ayırdığını fakat daha sonra öğretim programının çok gerisinde kaldığı için bu uygulamadan vazgeçtiğini ifade etmiştir.

Görüşmelerde ortaya çıkan bir diğer dikkat çekici bulgu ise sınıfların fiziksel yeterliliğinin ve öğrencilerin öğretim materyallerine (kaynaklara) erişiminin, öğretmenlerin beceri temelli soruları derslerinde kullanımını ciddi anlamda etkilemesidir. Sınıfta akıllı tahta bulunmadığında, örneğin, beceri temelli soruları derslerde kullanmanın öğretmenler için çok zor hale geldiği görülmektedir. T7 kodlu öğretmen hariç diğer tüm öğretmenlerin sınıflarında akıllı tahta bulunmaktadır. Akıllı tahtaya erişimi olan T2 kodlu öğretmen, beceri temelli sorunun çözümünü nasıl yaptı̆̆ını aşağıdaki sözler ile açıklamıştır.

T2: Tahtaya soruyu yansittyoruz sonra soruyu okuyorlar ögrenciler. Ben biraz bekliyorum. "Burada ne anladınız?" diye bazen soruyorum. Baktım ki bazen hiç kimseden bir şey çıkmıyor, mesela ufak bir sinıf tartışması şeklinde: "Burada ne soruyor bize, ne verilmiş?" gibi sorular soruyorum. Öğrencilerden gelen cevaplara göre işte "arkadaşınız bunu söylüyor sizce doğru mu, 
neyi bulmamız lazım, ya da bunu bulmak için sizce ne yapmamız lazım” gibi sorular sorarak çözmeye çalışlyorum.

T2'nin de bahsettiği üzere, öğretmenler genellikle soruları akıllı tahtaya yansıtmakta ve çözümleri için soru cevap tekniğini kullanmaktadır. T2 kodlu öğretmen, öğrencilerin problem bağlamını anlamasını sağlamak ve onları çözüm sürecine dâhil etmek için bazı sorular sorduğunu ifade etmektedir. Akıllı tahtaya erişimi olmayan T7 ise bu durumun olumsuz etkilerini aşağıdaki sözler ile ifade etmiştir.

T7: ...[beceri temelli] soruyu yazdıramıyoruz, yazdırmak zaten bir tahtayı kapllyor. Öğrenci de buna yetişemiyor. Biz soru yazdırmaya çalıştıkça müfredatın gerisinde kalıyoruz... Çünkü bir soruyu tahtaya yazmak en az 10 dakikamı allyor. Ögrencilerin yazmasl 15 hatta 20 dakika. Çözmemiz onların anlaması... Öğrenci tahtaya baklyor ve çok uzun bir soru görüyor ve diyor ki asla çözemem, belki kâğıtta çözse o kadar da korkmayacak. Kâğıttansa tahta daha çok ürkütüyor. Akıllı tahtamız yok. Daha gelmedi... Çıktı almak bir çözüm ama orada da şöyle bir problem var. 50-60 kişilik sinıflarda ders anlatıyoruz, bir süre sonra fotokopi ücretlerini ögretmenler olarak biz ödüyoruz. Her gün her gün fotokopi çektir bize külfet oluyor. Ben ögrencilerden toplama taraftar değilim, toplamıyorum. O sebepten bir yere kadar karşılayabiliyorum... Bir soru bir sayfayı kaplıyor. En az 10 soru çektirsen 10 kâğtt, ikili yapsan göremiyor, o da başka bir sıkıntı.

T7'nin de ifade ettiği gibi sınıfların fiziksel altyapı olarak yetersiz olması, örneğin akıllı tahtanın olmaması beceri temelli soruların sınıf içi kullanımını olumsuz olarak etkilemektedir.

\subsubsection{Beceri Temelli Soruların Yer Aldı̆̆g Kaynaklara Yönelik Görüşler}

Görüşmelerde öğretmenlere beceri temelli soruların yer aldığı kaynaklar ile ilgili görüşleri de sorulmuştur. Ortaya çıkan dikkat çekici bulgulardan biri MEB tarafından ücretsiz olarak verilen ders kitaplarında beceri temelli sorulara yeteri kadar yer verilmemesidir. Devlet okulunda çalışan 6 öğretmen (T2, T4, T5, T7, T8, T9), ders kitaplarında yer alan soruların beceri temelli sorular ile uyumlu olmadığını ifade etmiştir. Örneğin;

Araştırmacı: MEB'in ders kitabını beceri temelli sorular açısından nasıl değerlendirir misiniz?

T9: Milli Eğitimin 8. sınıf kitabındaki örneklerin çoğunluğu beceri temelli sorular ile bağlantılı değil. Ders kitabı ile sınavda çıkacak soru tarzı çok eşit seviyede değil ama daha çok konuyu pekiştirici, daha çok konuyu ögretici tarzda sorular, daha müfredat düzeyinde. Sinavda gelen sorular ise müfredattan ziyade matematiği bilme ve yorumlama ile alakalı. Böyle bir çelişki var. Ders kitabı sınava yönelik olarak ögrenciye yetmiyor.

T9 kodlu öğretmen, ders kitaplarındaki soruların daha çok konuyu pekiştirme adına alıştırma tarzında olduğunu ve beceri temelli sorular açısından kitapların yetersiz olduğunu ifade etmiştir. T9 ile benzer düşünceyi ifade eden T2 ise kitaplardaki sorular ile tamamı beceri temelli sorulardan oluşan LGS'de yer alan sorular arasındaki uyumsuzluğu öğrencilerin de fark ettiğini aşağıdaki sözlerle ifade etmiştir:

T2: Ama ders kitaplarında bir tane bile beceri temelli soru yok. Bu sefer ögrrenci de şöyle düşünmüş oluyor: Hani okulda bu kitabı kullanma zorunluluğu var, kitaptan işlemek zorundasın. Bizim karşımıza böyle sorular çıkmıyor ki, biz derste bunları işleyip sınavda neden başka türlü sorulara maruz kallyoruz? O yönden ders kitaplarda sikıntı var diyebilirim.

Yukarıdaki alıntıda da görüldüğü üzere T2 kodlu öğretmen ders kitaplarındaki sorularla LGS'deki beceri temelli soruların uyumsuzluğunu ve öğrencilerin de bunun farkında olduğunu dile getirmiştir.

Görüşme yapılan öğretmenlerin tamamı, derslerinde kullanmak ve öğrencilerine ulaştırmak adına beceri temelli soruların yer aldığı farklı kaynaklara başvurduklarını ve bunun için birçok kaynağı incelediklerini ifade etmiştir. Öğretmenlerin en yaygın olarak kullandıkları kaynaklardan biri MEB'in her ay örnek olarak yayınlandığı beceri temelli sorular diğeri ise özel yayınevleri tarafından yayınlanan kitaplardır. Öğretmenler MEB tarafından yayınlanan örnek soruların beceri temelli sorulara iyi birer örnek teşkil ettiğini düşünmekte olup derslerinde kullandıklarını ya da öğrencilere çözmeleri için verdiklerini ifade etmiştir. Örneğin,

T5: MEB'in yayınladı̆̆l örnek sorular gerçekten çok kaliteli, çok sade, çok düzgün Geçen yıl yayınlanan örnek sorularla yeni yayınlananlar arasındaki farkı incelerseniz ciddi bir gelişim olduğunu görebilirsiniz.

MEB'in yayınladığı örnek soruların yanı sıra öğretmenlerin tümü beceri temelli sorulara ulaşmak adına özel yayınevleri tarafından yayınlanan kitaplara başvurmaktadır. Bu konuda yayın yapan çok sayıda özel yayınevi olduğu için tek bir sonuca ulaşmak mümkün değildir. Fakat genel olarak öğretmenler bazı yayınevlerinin bu konuda kendini geliştirdiğini düşünse de birçok yayınevinin kaynaklarında yer alan beceri temelli soruların niteliğinin yetersiz olduğunu ifade etmiştir. Burada niteliğin yetersizliği öğretmenler tarafindan farklı olarak detaylandırılmıştır. Öğretmenler özel yayınevleri tarafından sunulan soruların anlaşılır olmadığını (T3), gereksiz 
uzunlukta işlem gerektirebildiğini (T2), beceri temelli soru özelliği taşımadığını (T1, T3, T5), sorunun neyi ölçtüğünün belirsiz olduğunu (T2), soru kökünün çok uzun olduğunu (T6), bazı soruların hatalı olduğunu (T5) ve MEB' in örnek sorularının kopyası (T6, T7) olduğunu düşünmektedir.

MEB'in yayınladığı örnek sorular ve farklı yayınevlerinin kaynaklarının yanı sıra öğretmenlerden bazıları kendi yazdıkları beceri temelli soruları da matematik derslerinde kullandıklarını ifade etmiştir. Özel okulda görev yapan T6, matematik zümresindeki öğretmenler tarafindan yazılan beceri temelli soruları derslerinde kullandığını ifade etmiştir.

\subsubsection{Beceri Temelli Sorularla İlgili Hizmet İçi Eğitim Faaliyetleri Gereksinimine Yönelik Görüşler}

Görüşmelerde son olarak öğretmenlere beceri temelli sorulara yönelik hizmet içi faaliyetlere dair görüşleri sorulmuştur. Özel okulda görev yapan T6 hariç diğer hiçbir öğretmen beceri temelli sorular ile ilgili bir hizmet içi eğitim faaliyetine katılmamıştır. T6 ise beceri temelli soruların ölçme-değerlendirilmesi üzerine kurumu tarafından düzenlenen bir hizmet içi eğitim faaliyetine katıldığını ifade etmiştir.

Öğretmenlerin çoğunluğu $(n=9)$ beceri temelli sorular konusunda profesyonel desteğe ihtiyaç duyduğunu ifade ederken sadece bir öğretmen (T8) bu konuda aksi görüş belirtmiş̧ir. Öğretmenler beceri temelli sorularla ilgili ihtiyaç duydukları hizmet içi eğitim faaliyetlerini farklı temalar altında ifade etmişlerdir. Bunlar; (i) beceri temelli soruların yazımı (T5, T6), (ii) beceri temelli soruların doğasını ve amacını anlama (T5, T7), (iii) beceri temelli soruların sınıf içi kullanımına yönelik stratejiler (T2, T10), (iv) beceri temelli sorulara yönelik problem çözme becerilerinin geliştirilmesi (T3), (v) öğrencilerin beceri temelli soruları nasıl algıladığıdır (T4). Örneğin, T5 kodlu öğretmen görüşmede şunları ifade etmiştir.

T5: Şöyle bir ihtiyaç bence var, bir kere ögretmenlerin bu yeni nesil sorulart sinufta çözmeyi kabullenmesi anlamında var. Ayrıca, işin mantı̆̆ının oturması bakımından, PISA mantığının ne olduğu, nedir, hangileri bu soru tarzına girer, girmez gibi konularda isteyen öğretmenlere profesyonel destek verilmeli diye düşünüyorum. Yani bu anlamda akademik camia ögretmenlere yardımcl olabilir. Öğretmenlerle akademisyenler birlikte çalışarak örneğin bu tür soruları уазта...

T5 kodlu öğretmen, beceri temelli soruların doğasının ve amacının anlaşılması konusunda bir hizmet içi eğitim faaliyetine ihtiyaç olduğunu ifade etmektedir. T5'in aksine beceri temelli sorulara yönelik hizmet içi eğitim faaliyetine ihtiyaç duymadığını ifade eden T8 kodlu öğretmen ise düşüncelerini şöyle açıklamıştır:

T8: Yok ihtiyaç duymuyorum. Dediğim gibi eskiden de yaplyorduk. Bizim matematik problemlerimiz hep vardı konuya göre. Ama şimdi artık her konunun içinde, her soru problem şeklinde sorulur oldu. Benzerlikte direkt üçgen çizilmezdi. Örneğin telefon, elektrik direkleri verilirdi. Bu şekilde problem vardı çok yabancı değiliz şimdi yeni nesil soru deniyor.

Deneyim yılı oldukça yüksek olan T8, beceri temelli soruları problem olarak gördüğünü ve daha önceki yıllarda da problemlere derslerinde yer verdiği için bu konuda bir desteğe ihtiyaç duymadığını ifade etmiştir.

\subsection{Beceri Temelli Sorulara Yönelik Öğretmen Görüşleri: Nicel Bulgular}

Anketten edilen nicel bulgular dört kategori altında toplanmıştır. Bu kategoriler: Beceri temelli soruların (i) doğasına, (ii) matematik derslerinde kullanımına, (iii) yer aldığı kaynaklara yönelik öğretmen görüşleri ve (iv) hizmet içi eğitim faaliyetlerine dair öğretmenlerin ihtiyaçlarıdır. Ancak öğretmenlerin seviye belirleme ve yerleştirmeye yönelik olan sınavlarda kullanılan beceri temelli soruları tanıyıp tanımadığını belirlemek amacıyla ankette ilk olarak daha önceki yıllara ait LGS ve PISA sorularını inceleyip incelemedikleri sorulmuştur. Öğretmenlerin \%98,6'sı (214 kişi) LGS'de geçmiş yıllara ait çıkmış soruları, \%76,5'i (166 kişi) PISA sorularını incelediğini ifade etmiştir.

\subsubsection{Beceri Temelli Soruların Doğasına Yönelik Öğretmen Görüşleri}

Nitel verilerden elde edilen bulgular yardımıyla hazırlanan ankette yer alan beceri temelli soruların doğasına yönelik ifadelere öğretmenlerin katılıp katılmama durumları Tablo 4'te yer almaktadır. 
Tablo 4. Öğretmenlerin beceri temelli sorulara dair görüşleri

\begin{tabular}{|c|c|c|c|c|c|c|}
\hline \multirow{2}{*}{ Değişkenler } & \multicolumn{2}{|c|}{ Katılmıyorum } & \multicolumn{2}{|c|}{ Kararsızım } & \multicolumn{2}{|c|}{ Katılıyorum } \\
\hline & $\mathbf{n}$ & $\%$ & $\mathbf{n}$ & $\%$ & $\mathbf{n}$ & $\%$ \\
\hline Beceri temelli soruların zor olduğunu düşünüyorum. & 68 & 31,3 & 42 & 19,4 & 107 & 49,3 \\
\hline $\begin{array}{l}\text { Beceri temelli soruların üst düzey düşünme becerilerini ölçtüğünü } \\
\text { düşünüyorum. }\end{array}$ & 13 & 6 & 32 & 14,7 & 172 & 79,3 \\
\hline $\begin{array}{l}\text { Beceri temelli sorularda formül ya da bilgi verilmesini doğru } \\
\text { buluyorum. }\end{array}$ & 24 & 11,1 & 20 & 9,2 & 173 & 79,7 \\
\hline $\begin{array}{l}\text { İşleme dayalı çok sayıda soru çözen öğrencilerin beceri temelli } \\
\text { sorularda başarılı olacağını düşünüyorum. }\end{array}$ & 121 & 55,8 & 57 & 26,3 & 39 & 18 \\
\hline $\begin{array}{l}\text { Beceri temelli soruların çalışan ve çalışmayan öğrencileri ayırt } \\
\text { ettiğini düşünüyorum. }\end{array}$ & 51 & 23,5 & 55 & 25,3 & 111 & 51,2 \\
\hline $\begin{array}{l}\text { Beceri temelli sorunların PISA sorularına benzer olduğunu } \\
\text { düşünüyorum. }\end{array}$ & 18 & 8,3 & 100 & 46,1 & 99 & 45,6 \\
\hline $\begin{array}{l}\text { Beceri temelli soruların ALES sorularına benzer olduğunu } \\
\text { düşünüyorum. }\end{array}$ & 28 & 12,9 & 41 & 18,9 & 148 & 68,2 \\
\hline Beceri temelli soruların gereksiz olduğunu düşünüyorum. & 174 & 80,2 & 31 & 14,3 & 12 & 5,5 \\
\hline $\begin{array}{l}\text { Beceri temelli sorularla kavramsal öğrenmenin daha iyi } \\
\text { gerçekleştiğini düşünüyorum. }\end{array}$ & 24 & 11,1 & 50 & 23 & 143 & 65,9 \\
\hline
\end{tabular}

Beceri temelli sorulara dair görüşlerde; öğretmenlerin \%49,3’ü beceri temelli soruların zor olduğunu ve \%79,3'ü üst düzey becerileri ölçtüğünü düşünmektedir. Öğretmenlerin \%79,7'si beceri temelli sorularda formül ya da bilgi verilmesini doğru bulmaktadır. Öğretmenlerin \%55,8’i işleme dayalı çok sayıda soru çözen öğrencilerin beceri temelli sorularda başarılı olacağını düşünmemekte ve \%51,2'si beceri temelli soruların çalışan ve çalışmayan öğrencileri ayırt ettiğini düşünmektedir. Öğretmenlerin \%46,1'i soruların PISA sorularına benzemesinde kararsızken \%45,6'sı PISA ve \%68,2'si ALES sorularına benzediğini düşünmektedir. Öğretmenlerin \%80,2'si beceri temelli soruların gereksiz olduğuna katılmazken \%65,9'u bu sorular sayesinde kavramsal öğrenmenin daha iyi gerçekleştiğini düşünmektedir.

Öğretmenlere göre öğrencilerin beceri temelli soruları çözerken zorlanma nedenlerinin zorlanma derecesine göre sıralama sonuçlarına ait analizler Tablo 5'te verilmiştir.

Tablo 5. Öğrencilerin beceri temelli soruları çözerken zorlanma nedenlerinin zorlanma derecesine göre betimleyici istatistikleri

\begin{tabular}{|c|c|c|c|c|c|c|c|c|c|}
\hline Değişkenler & $\mathbf{1}$ & 2 & 3 & 4 & 5 & 6 & 7 & $\overline{\boldsymbol{X}}$ & $\widetilde{\boldsymbol{X}}$ \\
\hline Soru kökünün uzun olması & 31 & 31 & 34 & 36 & 38 & 26 & 21 & 3,83 & 4 \\
\hline Öğrencinin okuduğunu anlamaması & 88 & 54 & 24 & 20 & 15 & 8 & 8 & 2,43 & 2 \\
\hline $\begin{array}{l}\text { Öğrencinin sorulardaki günlük hayat } \\
\text { durumlarına aşina olmaması }\end{array}$ & 7 & 26 & 37 & 37 & 29 & 27 & 54 & 4,62 & 5 \\
\hline $\begin{array}{l}\text { Öğrencinin görsel (tablo, grafik, şekil vb.) } \\
\text { okuma becerisinin zayıf olması }\end{array}$ & 11 & 23 & 34 & 39 & 35 & 46 & 29 & 4,47 & 5 \\
\hline Öğrencinin sorulara alışık olmaması & 14 & 21 & 30 & 26 & 47 & 46 & 33 & 4,57 & 5 \\
\hline $\begin{array}{l}\text { Öğrencinin matematiksel bilgisinin yetersiz } \\
\text { olması }\end{array}$ & 12 & 19 & 22 & 34 & 32 & 50 & 48 & 4,83 & 5 \\
\hline $\begin{array}{l}\text { Öğrencinin üst düzey düşünme becerilerinin } \\
\text { yetersiz olması }\end{array}$ & 54 & 43 & 36 & 25 & 21 & 14 & 24 & 3,25 & 3 \\
\hline
\end{tabular}

Öğretmenlere göre, öğrencilerin beceri temelli sorularda zorlanma nedenleri sırasıyla okuduğunu anlamama $(\bar{X}=2,43)$, üst düzey düşünme becerilerinin yetersiz olması $(\bar{X}=3,25)$, soru kökünün uzun olması $(\bar{X}=3,83)$, görsel (tablo, grafik, şekil vb.) okuma becerisinin zayıf olması $(\bar{X}=4,47)$, sorulara alışı olmaması $(\bar{X}=4,57)$, sorulardaki günlük hayat durumlarına aşina olmaması $(\bar{X}=4,62)$ ve matematiksel bilgisinin yetersiz olmasıdır $(\bar{X}=4,83)$.

\subsubsection{Beceri Temelli Soruların Derslerde Kullanımına Yönelik Görüşler}

Öğretmenlerin beceri temelli soruları sınıf içi uygulamalarında ve matematik sınavlarında nasıl kullandıklarına dair verilerden elde edilen analiz sonuçları Tablo 6'da verilmiştir. 
Tablo 6. Beceri temelli soruların kullanımına yönelik betimleyici istatistikler

\begin{tabular}{|c|c|c|c|}
\hline Değişkenler & & $\mathbf{n}$ & $\%$ \\
\hline Kullanılan sınıf seviyesi & Kullanmiyorum & 1 & 0,5 \\
\hline & 5. Sinif & 129 & 59,4 \\
\hline & 6. sinif & 149 & 68,7 \\
\hline & 7. sinif & 186 & 85,7 \\
\hline & 8. sinif & 202 & 93,1 \\
\hline Kullanılan matematik dersi & Zorunlu matematik dersi & 180 & 83,3 \\
\hline & Seçmeli matematik dersi & 148 & 68,5 \\
\hline & Okulda yapılan kurs ve/veya etüt dersi & 171 & 79,2 \\
\hline Zorunlu ve/veya seçmeli matematik & Her ders & 36 & 16,7 \\
\hline dersinde kullanma sıklığ 1 & Her hafta & 120 & 55,6 \\
\hline & İki haftada bir & 35 & 16,2 \\
\hline & Ayda bir & 25 & 11,6 \\
\hline Zorunlu ve/veya seçmeli matematik & Konuya girişte & 14 & 6,5 \\
\hline dersinde hangi aşamada kullanıldığı & Konuyu anlattıktan hemen sonra & 36 & 16,7 \\
\hline & Konu ile ilgili alıştırmaları çözdükten sonra & 155 & 71,8 \\
\hline & Ünite sonunda & 145 & 67,1 \\
\hline Matematik sınavında kullanma durumu & Kullanmiyorum & 63 & 29 \\
\hline & Her sinavda en az bir tane & 83 & 38,2 \\
\hline & Sinavın tamamında & - & - \\
\hline & Konuya göre karar veririm & 77 & 35,5 \\
\hline & Sınıf seviyesine göre karar veririm & 84 & 38,7 \\
\hline
\end{tabular}

Öğretmenler beceri temelli soruları en çok 8. sınıflarda kullanılırken $(\% 93,1)$ yine en çok zorunlu matematik derslerinde kullanılmaktadır $(\% 83,3)$. Zorunlu ve/veya seçmeli matematik derslerinde sıklıkla her hafta $(\% 55,6)$ beceri temelli soru kullanılırken çoğunlukla konu ile ilgili alıştırmalar çözüldükten sonra $(\% 71,8)$ ve ünite sonunda $(\% 67,1)$ kullanılmaktadır. Öğretmenlerin \%38,7’si sınavlarında beceri temelli soru kullanmaya sınıf seviyesine göre ve \%35,5'i konuya göre karar vermektedir. Öğretmenlerin \%38,2'si her sinavda en az bir tane beceri temelli soru kullanmaktayken ve \%29’u hiç kullanmaktadır.

Öğretmenlerin beceri temelli soruları sınıfta öğrencilere nasıl sunduklarına ve sınıfta nasıl kullandıklarına dair dağılımlara ve bu dağılımların çalıştıkları kuruma göre farklılık gösterip göstermediğine dair analizlere Tablo 7'de yer verilmiştir.

Tablo 7. Beceri temelli soruların sınıfta kullanım durumlarının çalışılan kurumlara göre dağılımı

\begin{tabular}{|c|c|c|c|c|c|c|c|c|}
\hline \multirow{3}{*}{ Değişkenler } & & \multicolumn{6}{|c|}{ Calısılan Kurum } & \multirow{3}{*}{$\mathbf{p}$} \\
\hline & & \multicolumn{2}{|c|}{ Toplam } & \multicolumn{2}{|c|}{ Devlet } & \multicolumn{2}{|c|}{ Özel } & \\
\hline & & $\mathbf{n}$ & $\%$ & $\mathbf{n}$ & $\%$ & $\mathbf{n}$ & $\%$ & \\
\hline \multirow{3}{*}{$\begin{array}{l}\text { Beceri temelli } \\
\text { soruları sinıfa } \\
\text { sunma durumu }\end{array}$} & Tahtaya yazarım. & 44 & 20,4 & 33 & 21,7 & 11 & 17,2 & 0,47 \\
\hline & $\begin{array}{l}\text { Öğrencilerin önünde sorular yazılı } \\
\text { materyal olarak bulunur. }\end{array}$ & 154 & 71,3 & 105 & 69,1 & 49 & 76,6 & \\
\hline & Akıllı tahta ile ekrana yansitırım. & 171 & 79,2 & 118 & 77,6 & 53 & 82,8 & \\
\hline \multirow{5}{*}{$\begin{array}{l}\text { Beceri temelli } \\
\text { soruları sınıfta } \\
\text { kullanma } \\
\text { durumu }\end{array}$} & Ödev verip, sınıfta kontrol ederim. & 110 & 50,9 & 72 & 47,4 & 38 & 59,4 & 0,38 \\
\hline & Öğrenciler bireysel olarak çalışır. & 109 & 50,5 & 72 & 47,4 & 37 & 57,8 & \\
\hline & Öğrenciler grup çalışması yapar. & 73 & 33,8 & 50 & 32,9 & 23 & 35,9 & \\
\hline & Sınıf tartışması yaptırırım. & 139 & 64,4 & 96 & 63,2 & 43 & 67,2 & \\
\hline & $\begin{array}{l}\text { Öğrencilerden gelen soruları bireysel } \\
\text { olarak çözerim. }\end{array}$ & 127 & 58,8 & 91 & 59,9 & 36 & 56,3 & \\
\hline Toplam & & 216 & 100 & 152 & 100 & 64 & 100 & \\
\hline
\end{tabular}

Beceri temelli soruları sınıfa sunarken öğretmenler en çok akıllı tahta ile ekrana yansıtmayı $(\% 79,2)$ ve öğrencilerin önünde soruların yazılı materyal olarak bulunmasını $(\% 71,3)$ tercih ederken en az tahtaya yazmayı $(\% 20,4)$ sunum yolu olarak kullanmaktadır. Öğretmenlerin beceri temelli soruları sınıfa sunma durumları çalıştıkları kuruma göre farklılık göstermemektedir $(\mathrm{p}>0,05)$. Öğretmenler beceri temelli soruları sınıfta kullanırken sırasıyla sınıf tartışması yaptırmayı $(\% 64,4)$, öğrencilerden gelen soruları bireysel olarak çözmeyi $(\% 58,8)$, ödev verip sınıfta kontrol etmeyi $(\% 50,9)$, öğrencilerin bireysel olarak çalışmasını $(\% 50,5)$ ve öğrencilerin grup çalışması yapmasını $(\% 33,8)$ tercih etmektedirler. Öğretmenlerin beceri temelli soruları sınıfta kullanma durumları çalıştıkları kuruma göre farklılık göstermemektedir ( $p>0,05)$. 


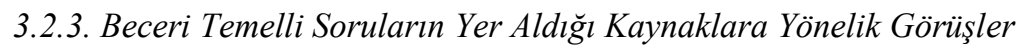

Öğretmenlerin beceri temelli soruları kullanırken tercih ettikleri kaynaklara ait veriler Tablo 8'de sunulmuştur.

Tablo 8. Beceri temelli sorular için kullanılan kaynakların dağılımı

\begin{tabular}{llcc}
\hline Değişkenler & n & \% \\
\hline Kullanılan kaynak türü & Kaynak kullanmıyorum & 4 & 1,8 \\
& MEB'in aylık yayınladı̆̆ı örnek sorular & 202 & 93,1 \\
& MEB ders kitabı & 75 & 34,6 \\
& Özel yayınevlerinin kitapları & 195 & 89,9 \\
& Kendi yazdığım sorular & 59 & 27,2 \\
& Zümre olarak hazırladı̆̆ımız sorular & 32 & 14,7 \\
& Çalıştığım kurumun yayınladı̆̆ı sorular & 18 & 8,3 \\
\hline
\end{tabular}

Beceri temelli soru kullanırken öğretmenler en çok MEB'in her ay yayınladığı örnek sorular (\%93,1) ile özel yayınevlerinin kitaplarını $(\% 89,9)$ tercih etmektedirler. Beceri temelli sorular kullanılırken en çok tercih edilen üç kaynağın öğretmenler tarafindan yapılan değerlendirme sonuçları Tablo 9'da verilmiştir.

Beceri temelli soruların yer aldığı kaynaklar, bu kaynakları kullanan öğretmenler tarafindan değerlendirildiğinde soru sayısı bakımından MEB'in aylık yayınladığı sorular $(\% 70,3)$ ve özel yayınevlerinin kitapları $(\% 77,9)$ uygun bulunurken MEB'in ders kitabının $(\% 41,3)$ uygun bulunma oranı daha düşüktür. Soru çeşitliliği bakımından MEB'in aylık yayınladığı sorular $(\% 72,8)$ ve özel yayınevlerinin kitapları $(\% 73,8)$ uygun bulunurken MEB'in ders kitabı konusunda kararsız kalınmakta $(\% 38,7)$ veya uygun bulunmamaktadır $(\% 37,3)$. Görsel kullanımı bakımından MEB'in aylık yayınladığı sorular (\%90,6), özel yayınevlerinin kitapları (\% 72,8$)$ ve MEB'in ders kitabı $(\% 53,3)$ uygun bulunmaktadır. Soruların anlaşılırlığı bakımından MEB'in aylık yayınladığ sorular $(\% 77,7)$ ve MEB'in ders kitabı $(\% 61,3)$ uygun bulunurken özel yayınevlerinin kitapları uygun bulunmamakta $(\% 21)$ veya kararsız kalınmaktadır $(\% 45,6)$. Sorunun günlük hayatla ilişkisi bakımından MEB'in aylık yayınladığı sorular $(\% 82,7)$, MEB'in ders kitabı $(\% 64)$ ve özel yayınevlerinin kitapları $(\% 53,8)$ uygun bulunmaktadır. Gerçek durumun problem niteliği bakımından MEB'in aylık yayınladığı sorular $(\% 70,8)$, MEB'in ders kitabı $(\% 57,3)$ ve özel yayınevlerinin kitapları $(\% 54,9)$ uygun bulunmaktadır. Sorunun zorluk seviyesi bakımından MEB'in aylık yayınladığı sorular $(\% 58,9)$, MEB'in ders kitabı (\%48) ve özel yayınevlerinin kitapları (\%40) uygun bulunmaktadır. Öğretim programlarındaki kazanımlara uygunluğu bakımından MEB'in aylık yayınladığı sorular $(\% 82,2)$, MEB'in ders kitabı $(\% 73,3)$ ve özel yayınevlerinin kitapları $(\% 65,6)$ uygun bulunmaktadır.

Tablo 9. Beceri temelli soruların yer aldığı kaynakların değerlendirilmesi

\begin{tabular}{|c|c|c|c|c|c|c|c|c|c|}
\hline \multirow[b]{2}{*}{ Değişkenler } & \multicolumn{3}{|c|}{$\begin{array}{l}\text { MEB'in aylık yayınladığı } \\
\text { sorular } \\
\text { (n=202) }\end{array}$} & \multicolumn{3}{|c|}{$\begin{array}{l}\text { MEB'in ders kitabı } \\
(n=75)\end{array}$} & \multicolumn{3}{|c|}{$\begin{array}{l}\text { Özel yayınevlerinin kitapları } \\
(n=195)\end{array}$} \\
\hline & $\begin{array}{c}\text { Uygun } \\
\text { değil } \\
\text { n } \\
(\%)\end{array}$ & $\begin{array}{c}\text { Kararsizi } \\
\mathbf{m} \\
\mathbf{n} \\
(\%)\end{array}$ & $\begin{array}{c}\text { Uygun } \\
\mathbf{n} \\
(\%)\end{array}$ & $\begin{array}{c}\text { Uygun } \\
\text { değil } \\
\mathbf{n} \\
(\%)\end{array}$ & $\begin{array}{c}\text { Kararsizım } \\
\mathbf{n} \\
(\%)\end{array}$ & $\begin{array}{c}\text { Uygun } \\
\mathbf{n} \\
(\%)\end{array}$ & $\begin{array}{c}\text { Uygun } \\
\text { değil } \\
\text { n } \\
(\%)\end{array}$ & $\begin{array}{c}\text { Kararsizım } \\
\mathbf{n} \\
(\%)\end{array}$ & $\begin{array}{c}\text { Uygun } \\
\mathbf{n} \\
(\%)\end{array}$ \\
\hline Soru say1s1 & $\begin{array}{c}35 \\
(17,3)\end{array}$ & $\begin{array}{c}25 \\
(12,4)\end{array}$ & $\begin{array}{c}142 \\
(70,3)\end{array}$ & $\begin{array}{c}31 \\
(41,3)\end{array}$ & $\begin{array}{c}22 \\
(29,3)\end{array}$ & $\begin{array}{c}22 \\
(29,3)\end{array}$ & $\begin{array}{c}10 \\
(5,1)\end{array}$ & $\begin{array}{c}33 \\
(16,9)\end{array}$ & $\begin{array}{c}152 \\
(77,9)\end{array}$ \\
\hline Soru çeşitliliği & $\begin{array}{c}14 \\
(6,9)\end{array}$ & $\begin{array}{c}41 \\
(20,3)\end{array}$ & $\begin{array}{c}147 \\
(72,8)\end{array}$ & $\begin{array}{c}28 \\
(37,3)\end{array}$ & $\begin{array}{c}29 \\
(38,7)\end{array}$ & $\begin{array}{l}18 \\
(24)\end{array}$ & $\begin{array}{c}13 \\
(6,7)\end{array}$ & $\begin{array}{c}38 \\
(19,5)\end{array}$ & $\begin{array}{c}144 \\
(73,8)\end{array}$ \\
\hline Görsel kullanımı & $\begin{array}{c}3 \\
(1,5)\end{array}$ & $\begin{array}{c}16 \\
(7,9)\end{array}$ & $\begin{array}{c}183 \\
(90,6)\end{array}$ & $\begin{array}{l}18 \\
(24)\end{array}$ & $\begin{array}{c}17 \\
(22,7)\end{array}$ & $\begin{array}{c}40 \\
(53,3)\end{array}$ & $\begin{array}{c}10 \\
(5,1)\end{array}$ & $\begin{array}{c}43 \\
(22,1)\end{array}$ & $\begin{array}{c}142 \\
(72,8)\end{array}$ \\
\hline Sorunun anlaş1lırlığ & $\begin{array}{c}9 \\
(4,5)\end{array}$ & $\begin{array}{c}36 \\
(17,8)\end{array}$ & $\begin{array}{c}157 \\
(77,7)\end{array}$ & $\begin{array}{l}12 \\
(16)\end{array}$ & $\begin{array}{c}17 \\
(22,7)\end{array}$ & $\begin{array}{c}46 \\
(61,3)\end{array}$ & $\begin{array}{c}45 \\
(23,1)\end{array}$ & $\begin{array}{c}89 \\
(45,6)\end{array}$ & $\begin{array}{c}61 \\
(31,3)\end{array}$ \\
\hline Günlük hayatla ilişkisi & $\begin{array}{c}1 \\
(0,5)\end{array}$ & $\begin{array}{c}34 \\
(16,8)\end{array}$ & $\begin{array}{c}167 \\
(82,7)\end{array}$ & $\begin{array}{c}7 \\
(9,3)\end{array}$ & $\begin{array}{c}20 \\
(26,7)\end{array}$ & $\begin{array}{l}48 \\
(64)\end{array}$ & $\begin{array}{l}13 \\
(6,7)\end{array}$ & $\begin{array}{c}77 \\
(39,5)\end{array}$ & $\begin{array}{c}105 \\
(53,8)\end{array}$ \\
\hline $\begin{array}{l}\text { Gerçek durumun } \\
\text { problem niteliği taşıması }\end{array}$ & $\begin{array}{c}5 \\
(2,5)\end{array}$ & $\begin{array}{c}54 \\
(26,7)\end{array}$ & $\begin{array}{c}143 \\
(70,8)\end{array}$ & $\begin{array}{c}8 \\
(10,7)\end{array}$ & $\begin{array}{c}24 \\
(32)\end{array}$ & $\begin{array}{c}43 \\
(57,3)\end{array}$ & $\begin{array}{c}14 \\
(7,2)\end{array}$ & $\begin{array}{c}74 \\
(37,9)\end{array}$ & $\begin{array}{c}107 \\
(54,9)\end{array}$ \\
\hline Zorluk seviyesi & $\begin{array}{c}21 \\
(10,4)\end{array}$ & $\begin{array}{c}62 \\
(30,7)\end{array}$ & $\begin{array}{c}119 \\
(58,9)\end{array}$ & $\begin{array}{l}18 \\
(24)\end{array}$ & $\begin{array}{l}21 \\
(28)\end{array}$ & $\begin{array}{c}36 \\
(48)\end{array}$ & $\begin{array}{c}44 \\
(22,6)\end{array}$ & $\begin{array}{c}73 \\
(37,4)\end{array}$ & $\begin{array}{c}78 \\
(40)\end{array}$ \\
\hline $\begin{array}{l}\text { Öğretim } \\
\text { programlarındaki } \\
\text { kazanımlara uygunluğu }\end{array}$ & $\begin{array}{c}17 \\
(8,4)\end{array}$ & $\begin{array}{c}19 \\
(9,4)\end{array}$ & $\begin{array}{c}166 \\
(82,2)\end{array}$ & $\begin{array}{c}6 \\
(8)\end{array}$ & $\begin{array}{c}14 \\
(18,7)\end{array}$ & $\begin{array}{c}55 \\
(73,3)\end{array}$ & $\begin{array}{c}24 \\
(12,3)\end{array}$ & $\begin{array}{c}43 \\
(22,1)\end{array}$ & $\begin{array}{c}128 \\
(65,6)\end{array}$ \\
\hline
\end{tabular}




\subsubsection{Beceri Temelli Sorularla İlgili Hizmet İçi Eğitim Faaliyeti Gereksinimine Yönelik Görüşler}

Öğretmenlerin beceri temelli sorular ile ilgili hizmet içi eğitime ihtiyaç duyup duymama ve hangi konularda ihtiyaç duyduklarına dair dağılımlar ve bu dağılımların çalıştıkları kuruma göre farklılık gösterip göstermediğine dair analizler Tablo 10'da yer almaktadır.

Tablo 10. Beceri temelli sorularla ilgili hizmet içi eğitim faaliyetlerine yönelik görüşlerin dağılımı

\begin{tabular}{|c|c|c|c|c|c|c|c|c|}
\hline \multirow{3}{*}{ Değişkenler } & & \multirow{2}{*}{\multicolumn{2}{|c|}{ Toplam }} & \multicolumn{4}{|c|}{ Çalışılan Kurum } & \multirow{3}{*}{$\mathbf{p}$} \\
\hline & & & & \multicolumn{2}{|c|}{ Devlet } & \multicolumn{2}{|c|}{ Özel } & \\
\hline & & $\mathbf{n}$ & $\%$ & $\mathbf{n}$ & $\%$ & $\mathbf{n}$ & $\%$ & \\
\hline \multirow{2}{*}{$\begin{array}{l}\text { Beceri temelli sorular hakkında } \\
\text { hizmet içi eğitim faaliyetlerine } \\
\text { ihtiyaç duyma }\end{array}$} & Evet & 129 & 59,4 & 88 & 57,5 & 41 & 64,1 & \multirow[t]{2}{*}{0,37} \\
\hline & Hayır & 88 & 40,6 & 65 & 42,5 & 23 & 35,9 & \\
\hline \multirow{6}{*}{$\begin{array}{l}\text { Beceri temelli sorular hakkında } \\
\text { ihtiyaç duyulan hizmet içi } \\
\text { eğitim faaliyet konuları }\end{array}$} & Soru yazımı & 105 & 81,4 & 74 & 84,1 & 31 & 75,6 & \multirow[t]{6}{*}{0,29} \\
\hline & $\begin{array}{l}\text { Problem çözme becerilerimi } \\
\text { geliştirme }\end{array}$ & 84 & 65,1 & 53 & 60,2 & 31 & 75,6 & \\
\hline & $\begin{array}{l}\text { Soruların sınıf içinde } \\
\text { kullanımı }\end{array}$ & 82 & 63,6 & 56 & 63,6 & 26 & 63,4 & \\
\hline & $\begin{array}{l}\text { LGS hakkında genel } \\
\text { bilgilendirme }\end{array}$ & 40 & 31 & 23 & 26,1 & 17 & 41,5 & \\
\hline & Soruların amacı & 49 & 38 & 33 & 37,5 & 16 & 39 & \\
\hline & $\begin{array}{l}\text { Var olan kaynakların } \\
\text { değerlendirilmesi }\end{array}$ & 73 & 56,6 & 50 & 56,8 & 23 & 56,1 & \\
\hline
\end{tabular}

Öğretmenlerin \%59,4'ü beceri temelli sorular hakkında hizmet içi eğitim faaliyetlerine ihtiyaç duyarken \%40,6'sı ihtiyaç duymamaktadır. Beceri temelli sorular hakkında hizmet içi eğitim faaliyetine ihtiyaç duyan öğretmenlerin tercih ettiği konular sırasıyla; (i) soru yazımı $(\% 81,4)$ (ii) problem çözme becerilerini geliştirme (\%65,1), (iii) soruların sınıf içinde kullanımı (\%63,6), (iv) var olan kaynakların değerlendirilmesi $(\% 56,6)$, (v) soruların amacı (\%38) ve (vi) LGS hakkında genel bilgilendirme (\%31) olmuştur.

Öğretmenlerin beceri temelli sorular ile ilgili hizmet içi eğitim faaliyetine katılıp katılmama durumlarına ve katılıyorsa hangi konularda olduğuna dair dağılımlar ve bu dağılımların çalıştıkları kuruma göre farklılık gösterip göstermediğine dair analizler Tablo 11'de yer almaktadır.

Tablo 11. Beceri temelli sorularla ilgili hizmet içi eğitim faaliyetlere katılım durumlarının dağı̆lımı

\begin{tabular}{|c|c|c|c|c|c|c|c|c|}
\hline \multirow{3}{*}{ Değişkenler } & \multirow{3}{*}{ (n) } & & & \multicolumn{4}{|c|}{ Çalıșılan Kurum } & \multirow{3}{*}{$\mathbf{p}$} \\
\hline & & \multicolumn{2}{|c|}{ Toplam } & \multicolumn{2}{|c|}{ Devlet } & \multicolumn{2}{|c|}{ Özel } & \\
\hline & & $\mathbf{n}$ & $\%$ & $\mathbf{n}$ & $\%$ & $\mathbf{n}$ & $\%$ & \\
\hline \multirow{2}{*}{$\begin{array}{l}\text { Beceri temelli sorular ile } \\
\text { ilgili hizmet içi eğitim } \\
\text { faaliyetlerine katılma } \\
\text { durumu }\end{array}$} & Evet & 32 & 14,7 & 14 & 9,2 & 18 & 28,1 & $0,00^{*}$ \\
\hline & Hayır & 185 & 85,3 & 139 & 90,8 & 46 & 71,9 & \\
\hline \multirow{6}{*}{$\begin{array}{l}\text { Beceri temelli sorular ile } \\
\text { ilgili katıldıkları hizmet içi } \\
\text { eğitim faaliyet konuları }\end{array}$} & Soru yazımı & 29 & 87,9 & 13 & 86,7 & 16 & 88,9 & $0,00^{*}$ \\
\hline & $\begin{array}{l}\text { Problem çözme becerilerimi } \\
\text { geliștirme }\end{array}$ & 21 & 63,6 & 8 & 53,3 & 13 & 72,2 & \\
\hline & $\begin{array}{l}\text { Soruların sınıf içinde } \\
\text { kullanımı }\end{array}$ & 13 & 39,4 & 3 & 20 & 10 & 55,6 & \\
\hline & $\begin{array}{l}\text { LGS hakkında genel } \\
\text { bilgilendirme }\end{array}$ & 9 & 27,3 & - & - & 9 & 50 & \\
\hline & Soruların amacı & 13 & 39,4 & 3 & 20 & 10 & 55,6 & \\
\hline & $\begin{array}{l}\text { Var olan kaynakların } \\
\text { değerlendirilmesi }\end{array}$ & 9 & 27,3 & 1 & 6,7 & 8 & 44,4 & \\
\hline
\end{tabular}

${ }^{*} \mathrm{p}<0,001$

Öğretmenlerin \%14,7'si beceri temelli sorularla ilgili bir hizmet içi eğitim faaliyetine katılmışken \%85,3’ü herhangi bir eğitim faaliyetine katılmamıştır. Hizmet içi eğitim faaliyetine katılan öğretmenler sırasıyla soru yazımı $(\% 87,9)$, problem çözme becerilerini geliştirme $(\% 63,6)$, soruların amacı $(\% 39,4)$, soruların sınıf içinde kullanımı $(\% 39,4)$, LGS hakkında genel bilgilendirme $(\% 27,3)$ ve var olan kaynakların değerlendirilmesi $(\% 27,3)$ konularında eğitim almışlardır. Öğretmenlerin beceri temelli sorularla ilgili hizmet içi eğitim faaliyetlerine ihtiyaç duyma $(p>0,05)$ ve eğer ihtiyaç duyuyorlarsa ihtiyaç duydukları konular $(p>0,05)$ çalı̧̧ıkları kurumun özel veya kamu olmasına göre farklılık göstermemektedir. Öğretmenlerin hizmet içi eğitim 
faaliyetlerine katılma durumları $(p<0,001)$ ve katıldıkları konular $(p<0,001)$ ise özel veya kamu kurumunda çalışma durumuna göre istatistiksel olarak anlamlı derecede farklılık göstermektedir.

Tablo 12. Beceri temelli sorular hakkında hizmet içi eğitim faaliyetlerine katılanların faaliyet hakkındaki görüşleri

\begin{tabular}{llcc}
\hline Değişkenler & & n & \% \\
\hline Beceri temelli sorularla ilgili katıldıkları hizmet içi eğitim & Evet & 14 & 42,4 \\
faaliyetini yeterli bulma durumu & Hayır & 19 & 57,6 \\
\hline
\end{tabular}

Beceri temelli sorular ile ilgili hizmet içi eğitim faaliyetine katılan öğretmenlerin bu faaliyetler hakkındaki görüşlerinin yer aldığı veriler Tablo 12 'de sunulmuştur. Öğretmenlerin \%42,4'ü beceri temelli sorular hakkında katıldıkları hizmet içi eğitim faaliyetini yeterli bulurken \%57,6'sı yeterli bulmamaktadır.

\subsection{Nitel ve Nicel Bulguların Beraber Analiz Edilmesi}

Bu bölümde görüşmelerden elde edilen nitel bulgular ve anketten elde edilen nicel bulgular daha önceki iki bölümde yer alan dört başlık altında karşılaştırılarak raporlanmıştır.

İlk olarak beceri temelli soruların doğasına yönelik bulgular incelendiğinde, öğretmenlerin çoğunlukla matematik öğrenimi ve öğretimi açısından beceri temelli soruları olumlu karşıladığı görülmektedir. Bunun yanı sıra matematik öğretmenlerinin beceri temelli soruları geleneksel sorulardan ayırt eden özelliklerinin (örn. üst düzey düşünme becerilerinin kullanımı) farkında oldukları görülmektedir. Ankete katılan öğretmenlerin yarıya yakını beceri temelli soruları zor bulduğunu, görüşmeye katılan öğretmenlerin ise tamamı özellikle öğrencilerin çözümlerde çok zorlandığını ifade etmiştir. Nitel ve nicel yöntemlerin her ikisi ile elde edilen bulgular yaşanan bu zorluğun genellikle soru kökünün uzun olmasından, öğrencinin okuduğunu anlamamasından ve öğrencinin üst düzey düşünme becerilerinin yetersiz olmasından kaynaklandığını göstermektedir.

Çalışmada ikinci olarak öğretmenlerin beceri temelli soruları sınıf içinde nasıl kullandıkları incelenmiştir. Bulgular, 8. sınıf düzeyinde en sık olmak üzere, 5. sınıf düzeyinden itibaren tüm ortaokul sinıf düzeylerindeki matematik derslerinde beceri temelli sorulara yer verildiğini göstermektedir. Beceri temelli soruların çoğunlukla konu ya da ünite sonunda kullanılması, çözümlerinde grup çalışmasının çok fazla tercih edilmemesi, çoktan seçmeli türünde olması gibi bulgular öğretmenlerin geleneksel soru çözümü şeklinde bir yöntem izlediklerine işaret etmektedir. Sınıf içi uygulamalarda dikkat çekici bir bulgu, fiziksel altyapının soruların derste kullanımında etkili olduğudur. Anket bulguları da soruların tahtaya yazılma yüzdesinin azımsanmayacak düzeyde olduğunu göstermektedir. Bu durum her iki okul türünde de fiziksel altyapı eksikliklerinin olabileceğine işaret etmektedir.

Bulgularda yer alan bir diğer başlık ise öğretmenlerin beceri temelli soruların yer aldığı kaynaklar ile ilgili görüşlerdir. Nitel bulgularda ön plana çıkan durum, öğretmenlerin matematik ders kitaplarını beceri temelli sorular açısından yetersiz bulmasıdır. Ankette de ders kitabının kullanılma yüzdesinin düşük olması ve ders kitabının soru sayısı bakımından çoğunlukla yetersiz bulunması bu bulguyu destekler niteliktedir. Öğretmenlerin büyük çoğunluğu MEB'in aylık yayınladığı beceri temelli soruları nitelik olarak uygun bulmakta ve kaynak olarak kullanmaktadır. Daha az sayıda öğretmenin ders kitaplarını kaynak olarak kullandıkları ve beceri temelli soru sayısı bakımından ders kitaplarının yetersiz olduğunu düşündükleri görülmektedir. Özel yayınevleri tarafından yayımlanan kitaplar öğretmenler tarafından çok kullanılan kaynaklardan biri olmakla birlikte, çoğunluğunun bu kitaplardaki beceri temelli soruların anlaşılırlık ve zorluk seviyesi bakımından uygun olmadığını düşündükleri görülmektedir.

Son olarak beceri temelli sorular ile ilgili hizmet içi eğitim faaliyetlerine yönelik hem nitel hem de nicel bulgular birbiri ile paralellik göstermektedir. Elde edilen bulgularda, öğretmenlerin az bir kısmının beceri temelli sorulara yönelik bir hizmet içi eğitim faaliyetine katıldığ 1 ve katılanların ise yarıdan fazlasının eğitimi yeterli bulmadığı görülmektedir. $\mathrm{Bu}$ açıdan bakıldığında, öğretmenlerin birçoğunun bu konudaki sınıf içi uygulamalarına dışarıdan bir destek almadan kendi bilgi ve geçmiş deneyimleri ile şekillendirdikleri söylenebilir. Öğretmenlerin büyük bir kısmının ifade ettiği gibi sınıf içi uygulamalarında beceri temelli sorulara konu anlatımını bitirdikten sonra, geleneksel soru çözümü şeklinde yer vermeleri, bunun bir göstergesi olabilir. Öğretmenler beceri temelli soruları bir şekilde sınıflarında uygulamaya çalışsalar da, bu konuda profesyonel desteğe ihtiyaçlarının olduğunu ifade etmişlerdir. Sonuç olarak, beceri temelli sorular, LGS sistemine geçiş ile birlikte matematik eğitiminin bağlamında gündemimize girmiştir. Yapılan görüşmeler ve anket sonuçları öğretmenlerin bu yeniliği kabullendiklerini ve bu türdeki sorulara matematik derslerinde bir şekilde yer vermeye çalıştıklarını göstermektedir. Fakat beceri temelli sorularla ilgili olarak öğretmenlerin profesyonel desteğe ihtiyaç duydukları da görülmektedir. 


\section{Tartışma ve Sonuç}

Türkiye 2004 yılından itibaren belirli aralıklarla öğretim programlarında reform ve güncellemeler yapmaktadır (Aksit, 2007; Özer-Özkan ve Acar-Güvendir, 2018). Fakat öğretim programlarında yapılan bu güncellemelerin, eğitim-öğretim açısından önemli felsefi değiş̧iklikler içermesine rağmen öğretmenlerin sınıf içi uygulamalarına yansıması çok az olmuştur (Aktepe ve ark., 2015; Duru ve Korkmaz, 2010; Temizöz ve ÖzgünKoca, 2008; Zembat, 2010). PISA'nın bir yansıması olarak LGS gibi merkezi sınavlarda beceri temelli sorular kullanılmasının, öğretim programlarında yapılan reformlara kıyasla öğretmenlerin sınıf içi uygulamalarını doğrudan ve daha fazla etkilediği görülmektedir. Bu çalışmadan elde edilen bulgular, Güler ve arkadaşlarının (2019) bulgularına paralel olarak, ortaokul matematik öğretmenlerinin beceri temelli soruları genel olarak matematik öğrenimi ve öğretimi açısından olumlu ve yerinde bulduklarını göstermektedir. Öğretmenlerin çoğunluğunun beceri temelli soruları derslerinde haftada bir, konu bittikten sonra veya ünite sonu gibi değişen sıklıklarla uygulamaya çalıştıkları ve yazılı sınavlarında bu sorulara yer verdikleri görülmektedir. Öğretmenlerin bu soruları 8. sınıf düzeyinde yoğun olmak üzere daha alt sınıf düzeylerinde de uygulandığı görülmektedir. Elde edilen bulgular, öğretmenlerin beceri temelli sorulara yönelik bir anlayış geliştirme ve uygulamalarının bir parçası haline getirme çabası içerisinde olduklarını göstermektedir.

Öte yandan, öğretmenlerin beceri temelli soruları derslerinde uygulama yöntemleri ve bu soruların gerektirdiği becerilere yönelik uyguladıkları diğer eğitim-öğretim faaliyetleri, PISA veya LGS etkisinin olumlu ve doğru yönde olduğuna dair tam bir gösterge oluşturmamaktadır. Öğretmenlerin genellikle beceri temelli soruları sınıf içi uygulamalarında sınıf tartışması, bireysel çözüm veya soru-cevap yöntemleri ile kullandıkları, grup çalışması yöntemi ile ise daha az kullandıkları görülmektedir. Örneğin, öğretmenlerin yaklaşık \%20’si bu soruları tahtaya yazarak çözmeye çalıştıklarını ifade etmişlerdir. Bu durum akıllı tahtanın olmaması gibi altyapı yetersizliği ile açıklanabileceği gibi öğretmenlerin geleneksel öğretmen merkezli öğretim metotlarını kullanmaya devam etmelerinin sonucu olarak da yorumlanabilir. Benzer şekilde, görüşme yapılanlar arasından sadece iki öğretmen, bu soruların gerektirdiği becerileri geliştirmeye yönelik olarak, öğrenciyi aktif kılan, biçimlendirici ölçme-değerlendirmenin etkin kullanıldığı, proje-tabanlı, STEM veya matematiksel modelleme gibi grup çalışması gerektiren ve gerçekçi problem durumları içeren uygulamaların gerekliliğinden bahsetmiştir. Beceri temelli sorularla ortaya çıkan öğretmenlerin kendi sınıf içi uygulamalarını güncelleme gereksinimi, yine öğretmen merkezli, geleneksel yöntemlerle bol sayıda soru çözme uygulamaları şeklinde vuku bulduğu görülmektedir.

Yine Güler ve arkadaşlarının (2019) ve Erden (2020)'nin çalışmalarında ortaya çıkan bulgulara paralel olarak, öğretmenlerin büyük çoğunluğu beceri temelli sorularla ilgili mesleki gelişim faaliyetine ihtiyaç duymaktadır. Bu noktada öğretmenlerin mesleki gelişim için desteğe ihtiyaç duyuyor olmaları, matematik öğretmenlerine öğrenci merkezli, aktif öğrenmenin gerçekleştirilebileceği pedagojik yaklaşımları benimsetmek için önemli bir firsat olarak görülmelidir. Merkezi sınavların öğretmen uygulamalarını olumlu veya olumsuz anlamda etkilediği bilinmektedir (Smith ve Rottenberg, 1991; Stecher, 2002). Beceri temelli sorular1 öğrenci merkezli öğretim yöntemleri ile matematik derslerinin doğal bir bileşeni haline getirilmesi, merkezi sınavların öğretmenlerin sınıf içi uygulamaları üzerine olumsuz etkilerinin önüne geçmeyi mümkün kılabilir. Ancak MEB'in yayınladığı soruların tamamının çoktan seçmeli olması, öğretmenlerin sınıf içi uygulamalarında öğrenciyi aktif kılan yöntemleri halen kullanmamalarının bir sebebi olabilir. PISA'da olduğu gibi açık uçlu soruları da kullanılarak beceri temelli soruların daha nitelikli hale getirilmesi, ögretmenlerin de sinıflarında öğrenci merkezli öğretim yöntemlerini kullanmasını destekleyici bir unsur olabilir. Nitekim beceri temelli sorular ile PISA sorularının benzerliği sorusuna öğretmenlerin yarıdan fazlasının kararsız oldukları veya benzer olmadığını düşündükleri görülmektedir (bkz. Tablo 4).

Tasarlanan hizmet içi eğitim faaliyetlerinde öğrenci merkezli öğretim uygulamalarına ve bunların öğrencilerin becerilerini nasıl geliştirdiğine yer verilmelidir. Öğretmenlere yönelik düzenlenecek hizmet içi eğitim faaliyetlerinde beceri temelli soruların yazımı, soruların matematik derslerinde nasıl uygulanacağı ve başka ne tür öğretim faaliyetlerinin öğrencilerde bu soruların gerektirdiği becerilere katkı sağlayabileceği gibi konulara öncelikli olarak yer verilmelidir (Güler ve ark., 2019; Erden, 2020). Bu öğretmenlerin mevcut ihtiyaçlarının giderilmesi ve onların sınıf içi uygulamalarını doğru yönlendirme bakımından önemlidir.

Ortaokul matematik öğretmenleri, MEB'in düzenli aralıklarla yayınladığı beceri temelli soruları en uygun ve en çok yararlandıkları kaynak olarak değerlendirmektedirler. Öğretmenlerin çoğunluğu, ders kitaplarını soru sayısı ve çeşidi bakımından, özel yayınevleri tarafından yayımlanan kaynakları ise soruların anlaşılırlığı ve zorluğu bakımından kararsız veya uygun değil olarak değerlendirmişlerdir (bkz. Tablo 9). Öğretmenlerin, beceri temelli sorularla ilgili kaynaklara ilişkin düşüncelerine genel olarak bakıldığında, nitelik ve çeşitlilik bakımından ilk yıllara kıyasla daha iyi bir durum ortaya çıkmaktadır. Güler ve arkadaşlarının (2019) yaptığı çalışmada çıkan sonuçlara göre LGS sınavının ilk yapıldığı 2018 yılında yeterli kaynak olmadığı için öğretmenler ALES ve PISA gibi farklı kaynaklardan faydalanma ihtiyacı duymaktaydılar. Mevcut durumda MEB'in yayınladığı soruların ve özel yayınevlerinin öğretmenlerin kaynak ihtiyacını önemli ölçüde giderdiği görülmektedir. Özellikle MEB'in 
aylık yayınladığı sorular öğretmenler için en saygın ve yol gösterici kaynak niteliğindedir. Bu nedenle, çoktan seçmeli soruların yanında, bu soruların gerektirdiği becerilere yönelik, MEB'in açık uçlu soru veya etkinlik örnekleri yayınlaması öğretmenlerin sınıf içi uygulamalarını olumlu yönde etkileyebilir. Fakat ders kitaplarında yeteri kadar beceri temelli soru olmaması ve özel yayınevlerinin kitaplarındaki soruların ise anlaşılırlık, zorluk seviyesi ve gerçek hayat bağlamlarının problem niteliği taşıması gibi yetersiz olarak görülen noktalar olması adaptasyon sürecinin halen devam ettiğini göstermektedir. Ayrıca, beceri temelli soruların ders kitaplarında henüz yeterli sayı ve çeşitlilikte olmaması, öğretmenlerin çoğunluğunun sınıf içi uygulamalarda ve yazılı sınavlarında az sayıda ve seyrek olarak kullanıyor olmalarına karşın LGS sınavının tamamının beceri temelli sorulardan oluşması, öğretim programı ile merkezi sınavın uyumsuzluğunun açık bir göstergesidir (Erden, 2020). $\mathrm{Bu}$ durum LGS sınavının geçerliliği bağlamında detaylı incelenmesi gereken önemli bir meseledir (Diamond, 2007; Koretz, 2005).

$\mathrm{Bu}$ çalışmada öğretmenlerin belirttikleri görüşler doğrultusunda, beceri temelli soruların niteliğine yönelik kapsamlı bir analiz çalışmasının yapılmasının gerekliliği de ortaya çıkmaktadır. Soruların problem çözme, analitik düşünme, yorumlama, okuduğunu anlama gibi becerileri ölçtüğü söylenmekle birlikte, tam olarak hangi becerilerin ölçüldüğü öğretmen ve öğrenciler için net bir şekilde açıklanmalıdır. Ayrıca okuduğunu anlama becerisinin çok önemli hale gelmesinden dolayı beceri temelli sorular anlaşılırlık ve Türkçe kullanımı bakımından incelenmeye değer görünmektedir (Turanlı, Kıran, Eş ve Coşkun, 2017). Ayrıca, kazanım temelli olarak yazılan öğretim programlarında bu becerilerin nasıl ortaya çıktığı veya nasıl ele alınacağı da çalışılması gereken bir diğer önemli konudur. Bu çalışma kapsamında öğretmenlerin de bazı kaynaklar için yeterli bulmadığı sorularda kullanılan bağlamların gerçekliği, soruların anlaşılırlığı, öğretim programı ile uyumu ve başka açılardan beceri temelli soruların kapsamlı bir analizi yapılmalıdır. LGS beceri temelli sorularında PISA'da gördüğümüz açık uçlu soruların kullanılmaması ve sadece çoktan seçmeli madde türünün kullanılması, fikri organize etme ve yazarak kendini ifade etme gibi bazı önemli becerilerin ölçülememesine sebebiyet vermektedir. Bu nedenle, daha önce planlanan fakat gerçekleştirilemeyen, LGS sınavı gibi merkezi sınavlardaki beceri temelli sorularda açık uçlu soruların da kullanılması gibi bazı iyileştirmeler, öğretmenlerin sınıf içi uygulamalarını da olumlu yönlendirme potansiyeli açısından, tekrar gündeme alınmalıdır.

\section{Ek 1. Anket}

Anketin tamamına aşağıdaki linkten ya da karekoddan erişebilirsiniz.

https://drive.google.com/file/d/1L7NaGPdxs69JVlR-Vd2BWrODr18vP2Xb/view?usp=sharing

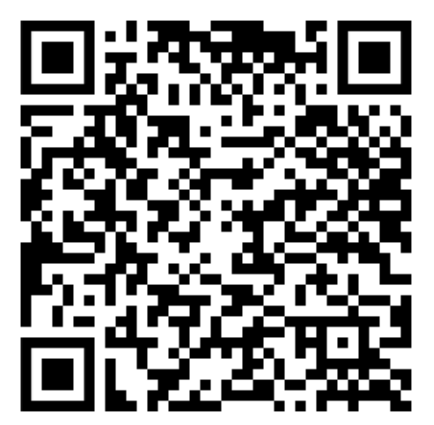

\section{Kaynaklar / References}

Aktepe, V., Tahiroğlu, M. ve Acer, T. (2015). Matematik öğretiminde kullanılan öğretim yöntemlerine ilişkin öğrenci görüşleri. Nevşehir Hacı Bektaş Veli Üniversitesi Sosyal Bilimler Enstitüsü Dergisi, 4(2), 127-143.

Aksit, N. (2007). Educational reform in Turkey. International Journal of Educational Development, 27(2), 129137.

Aydın, U., \& Özgeldi, M. (2019). The PISA tasks: unveiling prospective elementary mathematics teachers' difficulties with contextual, conceptual, and procedural knowledge. Scandinavian Journal of Educational Research, 63(1), 105-123.

Baştürk, S. (2011). Üniversiteye giriş sınavına hazırlanma sürecinin öğrencilerin matematik öğrenmeleri üzerine olumsuz yansımaları. Hacettepe Üniversitesi Eğitim Fakültesi Dergisi, 40, 69-79.

Blazar, D., \& Pollard, C. (2017). Does test preparation mean low-quality instruction? Educational Researcher, 46(8), 420-433. 
Breakspear, S. (2012). The policy impact of PISA: An exploration of the normative effects of international benchmarking in school system performance. OECD Education Working Papers No. 71. OECD Publishing: Paris.

Breakspear, S. (2014). How does PISA shape education policy making? Why how we measure learning determines what counts in education (Seminar Series 240). Melbourne: Centre for Strategic Education.

Cantley, I. (2019). PISA and policy-borrowing: A philosophical perspective on their interplay in mathematics education. Educational Philosophy and Theory, 51(12), 1200-1215.

Creswell, J., \& Plano-Clark, V. (2011). Designing and conducting mixed methods research (2nd ed.). Thousand Oaks, CA: Sage.

Çepni, S. (2019). PISA ve TIMSS sınavlarında başarıyı yakalamak için Türkiye ne yapmalı? S. Çepni (Ed.), PISA ve TIMSS mantığını ve sorularını anlama (2. bask1, ss. 393-404) içinde. Ankara: Pegem Akademi.

Çepni, S. ve Kaya, A. (2002). ÖSS sınavının liselerdeki fizik eğitim-öğretimine etkileri. Marmara Üniversitesi Atatürk Ĕ̈itim Fakültesi Ĕ̈itim Bilimleri Dergisi, 16, 39-48.

Çetin, A. ve Ünsal, S. (2019). Merkezi sınavların öğretmenler üzerinde sosyal, psikolojik etkisi ve öğretmenlerin öğretim programı uygulamalarına yansıması. Hacettepe Üniversitesi Eğitim Fakültesi Dergisi, 34(2), 304323.

Diamond, J. B. (2007). Where the rubber meets the road: Rethinking the connection between high-stakes testing policy and classroom instruction. Sociology of Education, 80(4), 285-313.

Duru, A. ve Korkmaz, H. (2010). Öğretmenlerin yeni matematik programı hakkındaki görüşleri ve program değişim sürecindeki karşılaş1lan zorluklar. Hacettepe Üniversitesi Eğitim Fakültesi Dergisi, 38, 67-81.

Erden, B. (2020). Türkçe, matematik ve fen bilimleri dersi beceri temelli sorularına ilişkin öğretmen görüşleri. Academia Ë̆itim Araştırmaları Dergisi, 5(2), 81-103.

Gay, L. R., Mills, G. E., \& Airasian, P. (2006). Educational research (8th ed.). Ohio: Pearson.

Greene, J. C., Caracelli, V. J., \& Graham, W. F. (1989). Toward a conceptual framework for mixed-method evaluation designs. Educational Evaluation and Policy Analysis, 11(3), 255-274.

Grek, S. (2009). Governing by numbers: The PISA 'effect' in Europe. Journal of Education Policy, 24(1), 2337.

Gürbüz, M. Ç. (2019). Uluslararası sınavların ve bazı ülkelerin merkezi sınav sistemlerinin ve soru örneklerinin tanıtımı. S. Çepni (Ed.), PISA ve TIMSS mantı̆̆ını ve sorularını anlama içinde (2. baskı, ss. 45-110). Ankara: Pegem Akademi.

Gürlen, E., Demirkaya, A. S. ve Doğan, N. (2019). Uzmanların PISA ve TIMSS sınavlarının eğitim politika ve programlarına etkisine ilişkin görüşleri. Mehmet Akif Ersoy Üniversitesi Eğitim Fakültesi Dergisi, 52, 287319.

Güler, M., Arslan, Z. ve Çelik, D. (2019). 2018 Liselere Giriş Sınavına ilişkin matematik öğretmenlerinin görüşleri. Van Yüzüncü Yıl Üniversitesi Eğitim Fakültesi Dergisi, 16(1), 337-363.

Güler, H. K. ve Ülger, B. B. (2019). PISA, TIMSS ve TEOG sınavlarının temel aldığı öğrenme kuramları. S. Çepni (Ed.) PISA ve TIMSS mantığını ve sorularını anlama içinde (2. baskı, ss. 111-153). Ankara: Pegem Akademi.

İpek, J., Turgut, G. Y. ve Tunga, Y. (2016). Matematik öğretmen adaylarının PISA ve TIMMS sınavları hakkındaki görüşleri. International Journal of Innovative Research in Education, 3(1), 32-41.

Kabael, T. (2019). Matematik okuryazarlığı ve PISA. T. Kabael (Ed.), Matematik okuryazarlı̆̆ ve PISA içinde (ss.11-43). Ankara: Anı Yayıncılik.

Kabael, T. ve Barak, B. (2016). Ortaokul matematik öğretmen adaylarının matematik okuryazarlık becerilerinin PISA soruları üzerinden incelenmesi. Türk Bilgisayar ve Matematik Eğitimi Dergisi, 7(2), 321-349.

Karip, E. (2020). PISA'da okuma performansı ve ögrencilerin okul yaşamı. https://tedmem.org/download/pisada-okuma-performansi-ogrencilerin-okul-yasami adresinden 29.06.2020 tarihinde erişilmiştir.

Koretz, D. (2005). Alignment, high stakes, and the inflation of test scores [Report 655]. Los Angeles, CA: National Center for Research on Evaluation, Standards, and Student Testing (CRESST) Center for the Study of Evaluation (CSE) Graduate School of Education \& Information Studies, University of California.

Kumandaş, H. ve Kutlu, Ö. (2014). Yükseköğretime öğrenci seçmede ve yerleştirmede kullanılan sınavların oluşturduğu risk faktörlerinin okul başarısı üzerindeki etkileri. Türk Psikoloji Dergisi, 29(74), 15-31.

Linn, R. L. (2000). Assessments and accountability. Educational Researcher, 29(2), 4-16.

Miles, M. B., \& Huberman, A. M. (1994). Qualitative data analysis: An expanded sourcebook (2nd ed.). Thousand Oaks, CA: Sage.

Miller, M. D., Linn, R. L., \& Gronlund, N. E. (2009). Measurement and assessment in teaching (10th ed.). Upper Saddle River, NJ: Prentice Hall.

Milli Eğitim Bakanlığg [MEB]. (2019). Millî ĕgitim istatistikleri, örgün ĕgitim 2018/'19. Ankara: Yazar.

Nichols, S. L. (2007). High-stakes testing: Does it increase achievement? Journal of Applied School Psychology, 23(2), 47-64. 
Organisation for Economic Co-operation and Development [OECD] (2018). Preparing our youth for an inclusive and sustainable world. The OECD PISA global competence framework, Paris: OECD.

Ormancı, Ü. (2019). Türkiye'de ulusal sınavların tanıtımı. S. Çepni (Ed.), PISA ve TIMSS mantığını ve sorularını anlama içinde (2. baskı, ss. 33-44). Ankara: Pegem Akademi.

Özer-Özkan, Y. ve Acar-Güvendir, M. (2018). Merkezi sınavların öğretmenler üzerindeki öğretimsel ve duyuşsal etkilerini belirlemeye yönelik öğretmen ölçeğinin geliştirilmesi. Inönü Üniversitesi Eğitim Fakültesi Dergisi, 19(3), 189-204.

Radišić, J., \& Baucal, A. (2018). Teachers' reflection on PISA items and why they are so hard for students in Serbia. European Journal of Psychology of Educational, 33, 445-466.

Resnick, L. B., \& Resnick, D. P. (1992). Assessing the thinking curriculum: New tools for educational reform. In B. G. Gifford, \& M. C. O'Conner (Eds.), Changing assessments: Alternative views of aptitude, achievement and instruction (pp. 37-75). Boston: Kluwer Academic Publishers.

Smith, M. L., \& Rottenberg, C. (1991). Unintended consequences of external testing in elementary schools. Educational Measurement: Issues and Practice, 10, 7-11.

Stecher, B. M. (2002). Consequences of large-scale, high-stakes testing on school and classroom practice. In L. Hamilton, B. M. Stecher, \& S. Klein (Eds.), Making sense of test-based accountability in education (pp. 79100). Santa Monica, CA: RAND.

Taş, U. E., Arıcı, Ö., Ozarkan, H. B. ve Özgürlük, B. (2016). PISA 2015 ulusal raporu. Ankara: MEB.

Teddlie, C., \& Tashakkori, A. (2009). Foundations of mixed methods research: Integrating quantitative and qualitative approaches in the social and behavioral sciences. Thousand Oaks, CA: Sage.

TEDMEM (2017). PISA'nın dönüşümü. https://tedmem.org/mem-notlari/degerlendirme/pisanin-donusumu adresinden 10.02.2020 tarihinde erişilmiştir.

Temizöz, Y. ve Özgün-Koca, A. S. (2008). Matematik öğretmenlerinin kullandıkları öğretim yöntemleri ve buluş yoluyla öğrenme yaklaşımı konusundaki görüşleri. Eğitim ve Bilim, 33(149), 89-103.

Turanlı, N., Kıran, A., Eş, A. H. ve Coşkun, M. (2017). Ulusal ve uluslararası matematik sınav sorularının karşılaştırmalı olarak anlaşılırlığının incelenmesi. International Journal of Social Sciences and Education Research, 3(5), 1892-1903.

Yıldırım, A. ve Şimşek, H. (2018). Sosyal bilimlerde nitel araştırma yöntemleri (11. baskı). Ankara: Seçkin Yayınlar1.

Zembat, İ. Ö. (2010). A micro-analysis of unified mathematics curricula in Turkey. ZDM Mathematics Education, 42, 443-455. 